ZENTRUM

FÜR BIODIVERSITÄT UND NACHHALTIGE LANDNUTZUNG

SEKTION

BIOdIVERSITÄT, ÖKOLOGIE UND NATURSCHUTZ

- Centre of Biodiversity and Sustainable Land Use -

SECTION: BIOdIVERsity, ECOlogy ANd Nature Conservation

\title{
Grassland Management and Diversity Effects on Soil Nitrogen Dynamics and Losses
}

\author{
Dissertation zur Erlangung des Doktorgrades der \\ Mathematisch-Naturwissenschaftlichen Fakultäten der \\ Georg-August-Universität Göttingen
}

vorgelegt von

Diplom Umweltwissenschaftlerin

Ina Hoeft

aus

Stade

Göttingen, Januar 2012 
Referentin/Referent:

Korreferentin/Korreferent:
Prof. Dr. Edzo Veldkamp

\author{
Dr. Marife D. Corre
}

Tag der mündlichen Prüfung: $\quad$ 27.02.2012 


\section{TABLE OF CONTENTS}

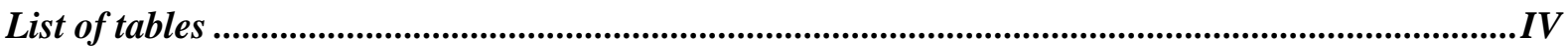

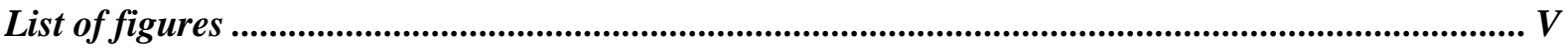

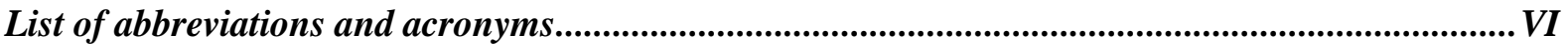

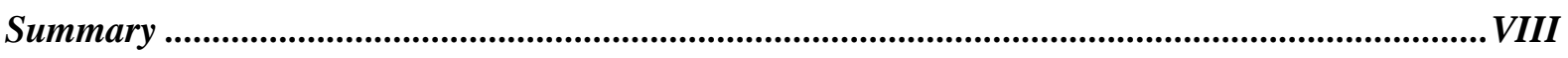

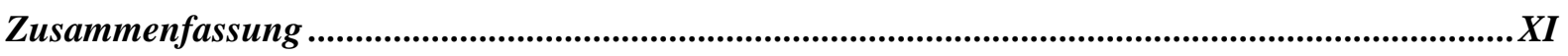

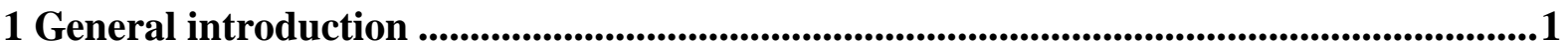

1.1 Temperate grasslands - management and biodiversity ................................................2

1.2 Nitrogen in temperate grassland ecosystems............................................................................3

1.3 Experimental sites...............................................................................................................5

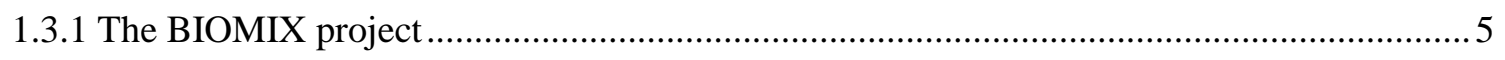

1.3.2 The GRASSMAN project …................................................................................ 7

1.4 Methodical outline of nitrogen losses and nitrogen dynamics ..................................9

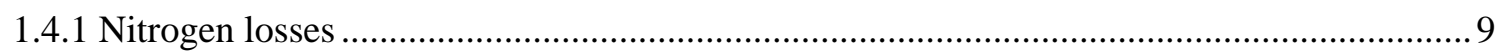

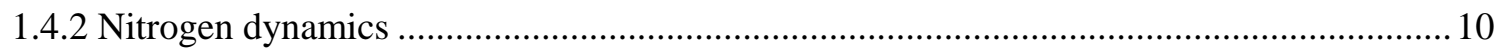

1.4.3 Calculation of nitrogen response efficiency and nitrogen retention efficiency .................... 11

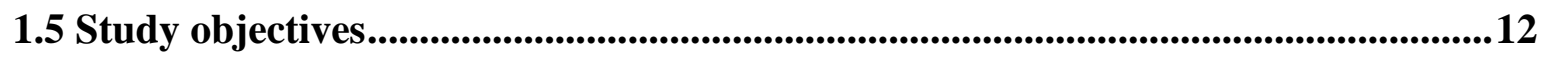

2 Response of nitrogen oxide emissions to grazer species and plant species composition in temperate agricultural grassland .........................................................................................14

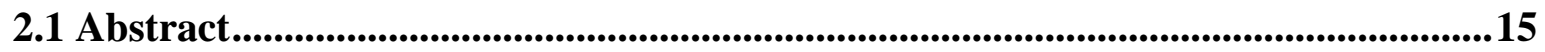

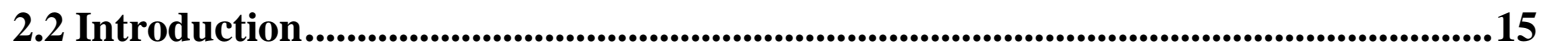

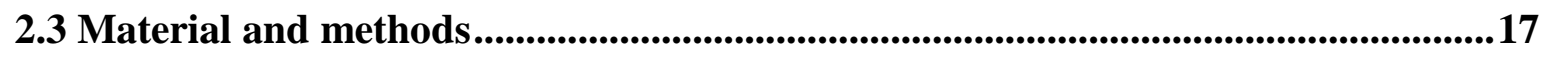

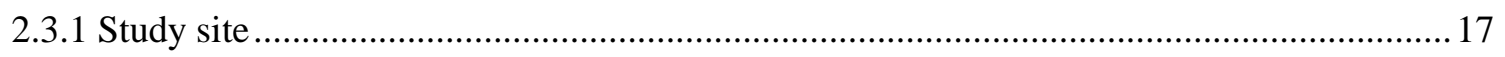

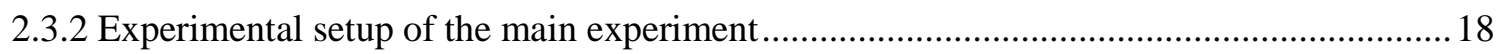

2.3.3 Experimental setup of the controlled application experiment .............................................. 19

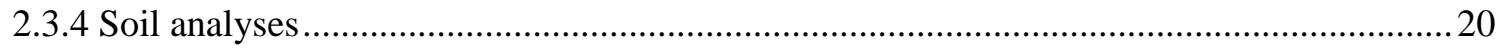

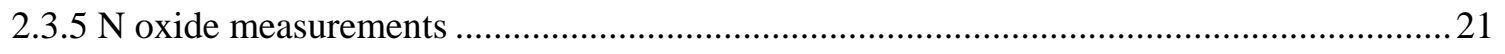

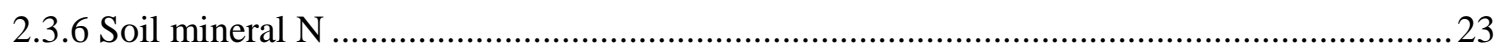

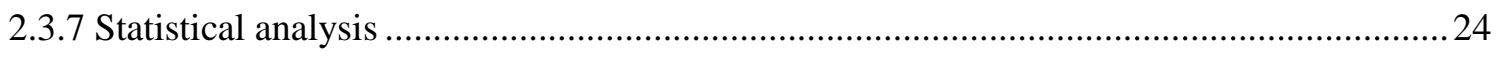

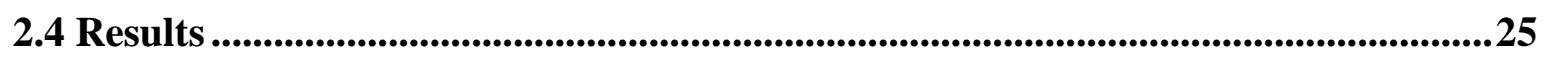


2.4.1 $\mathrm{N}$ oxide emissions and soil controls of the main experiment .25

2.4.2 $\mathrm{N}_{2} \mathrm{O}$ emissions and soil controls of the controlled application experiment

2.4.3 Emission factors and calculation of excreta $\mathrm{N}$ input and $\mathrm{N}_{2} \mathrm{O}$-losses on the paddock scale31

2.5 Discussion. 32

2.5.1 Grazer effects on $\mathrm{N}$ oxide emissions 32

2.5.2 Effects of sward composition on $\mathrm{N}$ oxide emissions.

2.6 Conclusions.

3 Nitrogen response efficiency of a managed and phytodiverse temperate grassland ....35

3.1 Abstract. .36

3.2 Introduction. .36

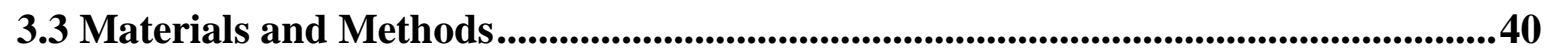

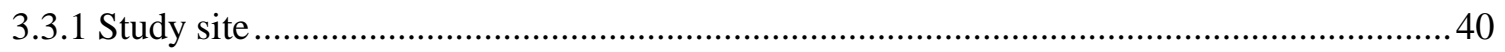

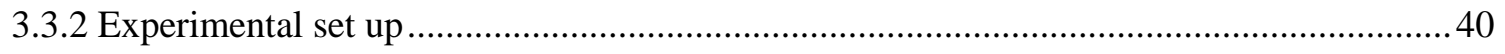

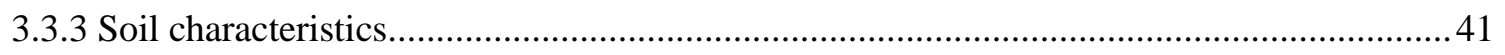

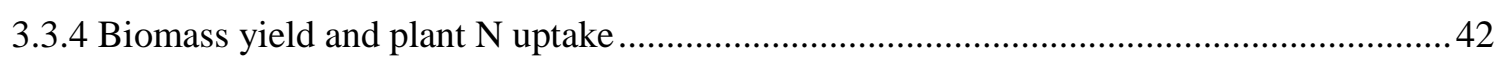

3.3.5 Soil net $\mathrm{N}$ mineralization rates, $\mathrm{N}$ supply, and $\mathrm{N}$ response efficiency ............................... 43

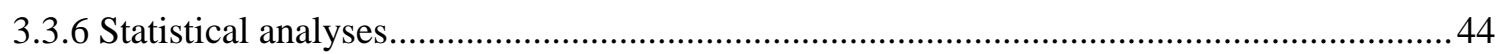

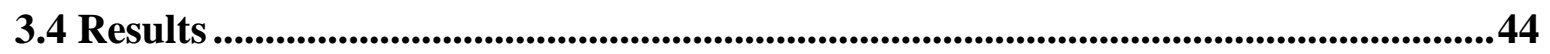

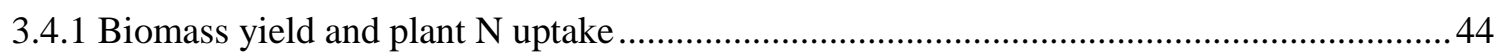

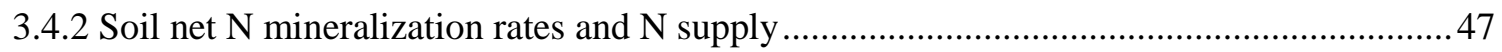

3.4.3 $\mathrm{N}$ response efficiency, $\mathrm{N}$ uptake efficiency and $\mathrm{N}$ use efficiency .....................................49

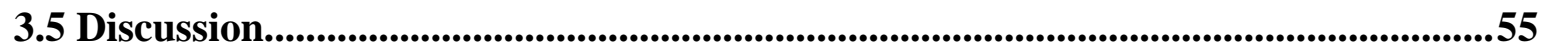

3.5.1 Soil net $\mathrm{N}$ mineralization, plant $\mathrm{N}$ uptake and biomass yield ..........................................55

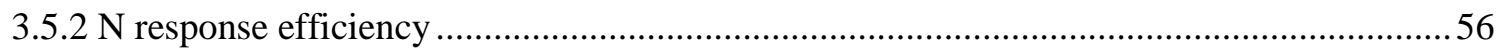

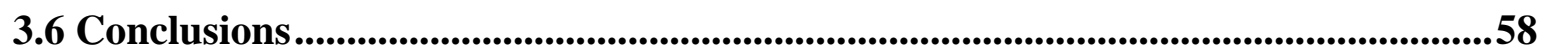

4 Nitrogen retention efficiency and nitrogen losses of a managed and phytodiverse

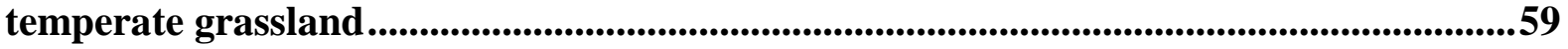

4.1 Abstract................................................................................................................................60

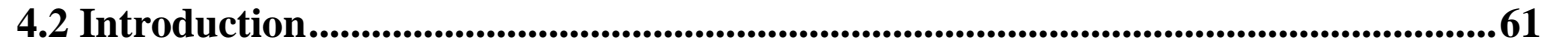

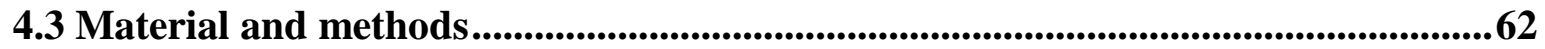

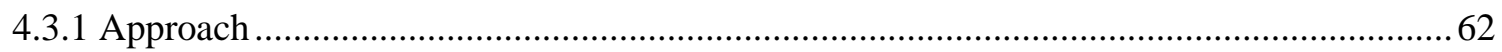


4.3.2 Study site 63

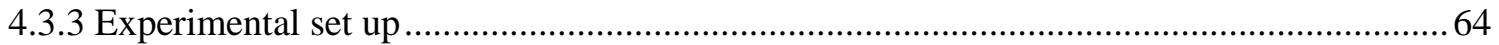

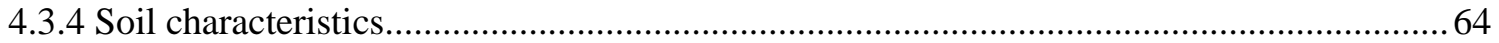

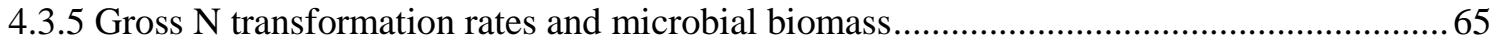

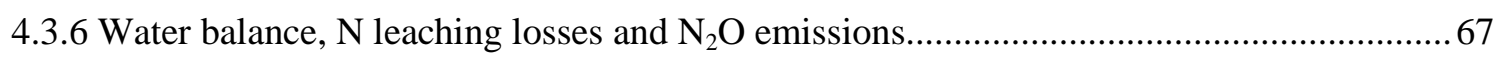

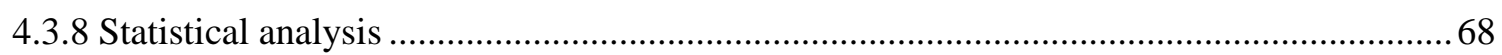

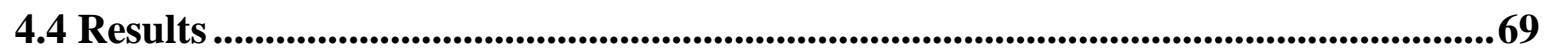

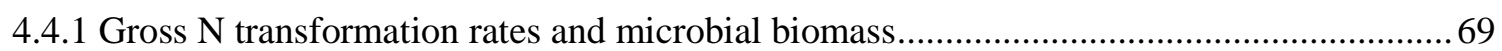

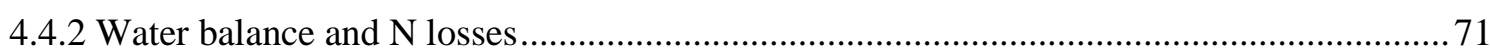

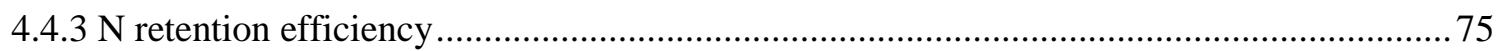

4.5 Discussion.................................................................................................................78

4.5.1 Gross $\mathrm{N}$ transformation rates and microbial biomass.............................................. 78

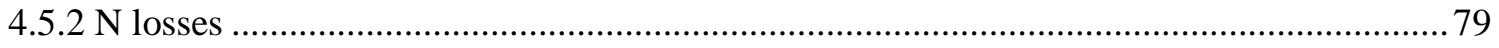

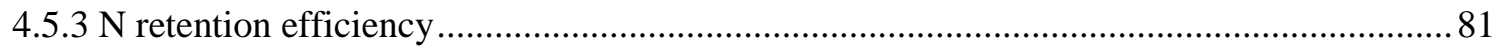

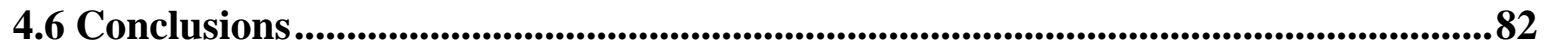

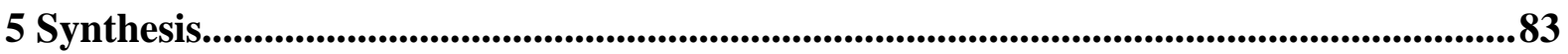

5.1 Synthesis and discussion of the major findings..............................................................84

5.1.1 The effects of livestock grazing on ecosystem functioning ........................................8 84

5.1.2 The effects of management intensity (fertilization and mowing) on ecosystem functioning

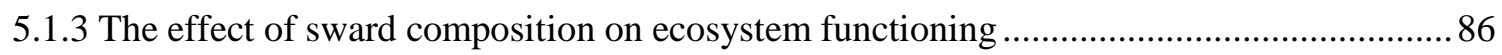

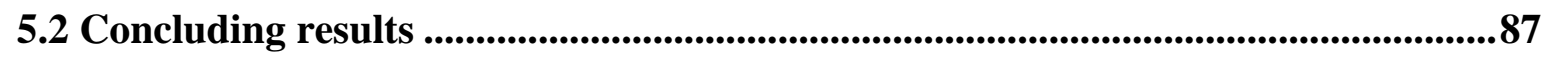

5.3 Implications and suggestions for further research .............................................87

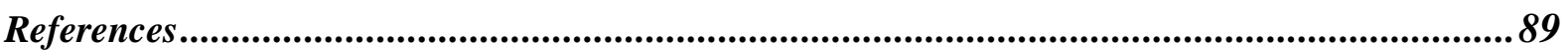

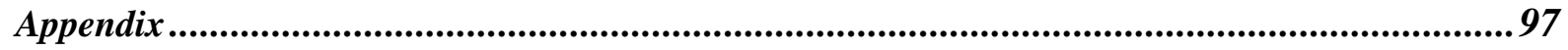

Acknowledgements ..................................................................................... 100

Declaration of originality and certificate of authorship ....................................................... 102

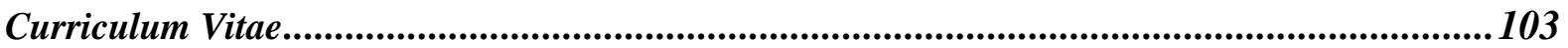




\section{LIST OF TABLES}

Table 2.1 Set up of the controlled application experiment.............................20

Table 2.2 Soil characteristics in the Ah horizon of the treatments in BIOMIX...............21

Table 2.3 Mean N oxide emissions and cumulative $\mathrm{N}$ oxide emissions....................25

Table 2.4 $\mathrm{N}_{2} \mathrm{O}-\mathrm{N}$ emissions and emission factors in the controlled application experiment and calculated $\mathrm{N}$ input with excreta and $\mathrm{N}_{2} \mathrm{O}$ losses in the main experiment.................31

Table 3.1 Soil characteristics in the Ah horizon of a Haplic Cambisol in GRASSMAN......42

Table 3.2 Plant $\mathrm{N}$ uptake of a grassland under different management practices.............46

Table 3.3 Soil net $\mathrm{N}$ mineralization rates of a grassland under different management

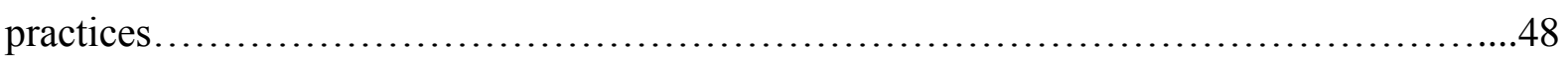

Table 3.4 N response efficiency of a grassland under different management practices......50

Table 3.5 $\mathrm{N}$ uptake efficiency of a grassland under different management practices........53

Table 3.6 $\mathrm{N}$ use efficiency of a grassland under different management practices............54

Table 4.1 Soil characteristics in the Ah horizon of a Haplic Cambisol in GRASSMAN.....65

Table 4.2 Gross $\mathrm{N}$ mineralization and nitrification rates under different management

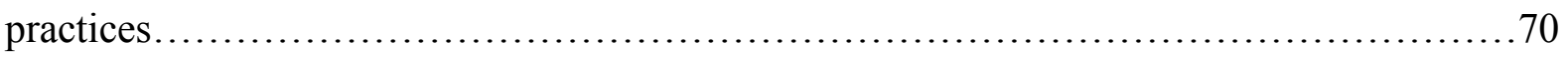

Table 4.3 N retention efficiency of a grassland under different management practices......76

Table 4.4 Spearman rank correlations between $\mathrm{N}$ retention efficiency and plant and soilmicrobial parameters........................................................ 77

Table A.1 Biomass yield of a grassland under different management practices.............99 


\section{LIST OF FIGURES}

Figure 1.1 Location of the BIOMIX and GRASSMAN study sites in the Solling Mountains, Lower Saxony, Germany...........................................................

Figure 1.2 Experimental design of BIOMIX ............................................

Figure 1.3 Experimental design of GRASSMAN $\ldots \ldots \ldots \ldots \ldots \ldots \ldots \ldots \ldots \ldots \ldots \ldots \ldots \ldots . . . \ldots$

Figure 1.4 Field and laboratory equipment for soil trace gas measurements and analysis....10

Figure 2.1 Daily air temperature and precipitation rate of the main experiment in 2008

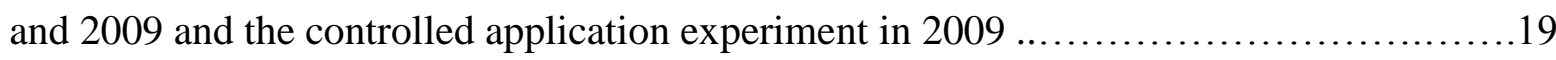

Figure 2.2 Mean $\mathrm{N}$ oxide emissions of the main experiment ...........................26

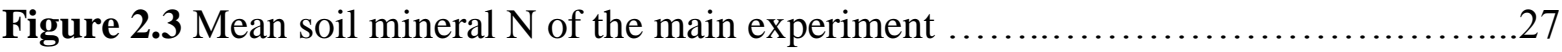

Figure 2.4 $\mathrm{N}_{2} \mathrm{O}-\mathrm{N}$ emissions of the controlled application experiment....................28

Figure 2.5 Soil mineral $\mathrm{NH}_{4}{ }^{+}$of the controlled application experiment..................29

Figure 2.6 Soil mineral $\mathrm{NO}_{3}{ }^{-}$of the controlled application experiment..................30

Figure 3.1 Trends between $\mathrm{N}$ response efficiency and $\mathrm{N}$ supply, $\mathrm{N}$ uptake efficiency

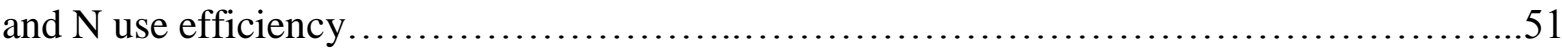

Figure 4.1 $\mathrm{NO}_{3}{ }^{-}$and DON leaching losses under different management practices............72

Figure 4.2 $\mathrm{N}_{2} \mathrm{O}$ emissions under different management practices......................74

Figure A.1 BIOMIX experiment with different swards in spring $2008 \ldots \ldots \ldots \ldots \ldots \ldots \ldots . .97$

Figure A.2 BIOMIX experiment with cattle and sheep grazing in spring $2008 \ldots \ldots \ldots \ldots \ldots . .97$

Figure A.3 GRASSMAN experiment in summer 2009. Photograph: Laura Rose...........98 


\section{LIST OF ABBREVIATIONS AND ACRONYMS}

\begin{tabular}{|c|c|}
\hline $\mathrm{AIC}$ & Akaike information criterion \\
\hline $\mathrm{BaCl}_{2}$ & Barium chloride \\
\hline BS & Base saturation \\
\hline $\mathrm{C}$ & Carbon \\
\hline CEC & Cation exchange capacity \\
\hline CFIC & Continuous flow injection colorimetry \\
\hline $\mathrm{CO}_{2}$ & Carbon dioxide \\
\hline $\mathrm{CrO}_{3}$ & Chromium trioxide \\
\hline DON & Dissolved organic nitrogen \\
\hline $\mathrm{EF}$ & Emission factor \\
\hline ET & Evapotranspiration \\
\hline $\mathrm{Fe}$ & Iron \\
\hline GC & Gas chromatograph \\
\hline $\mathrm{H}_{2} \mathrm{O}$ & Water \\
\hline $\mathrm{H}_{2} \mathrm{O}_{2}$ & Hydrogen peroxide \\
\hline ICP-OES & Inductively coupled plasma - optical emission spectroscopy \\
\hline IPCC & Intergovernmental Panel on Climate Change \\
\hline $\mathrm{K}$ & Potassium \\
\hline $\mathrm{K}_{2} \mathrm{SO}_{4}$ & Potassium sulphate \\
\hline LME & Linear mixed effects model \\
\hline Mol & Mole \\
\hline $\mathrm{N}$ & Nitrogen \\
\hline${ }^{14} \mathrm{~N}$ & Stable N isotope, frequency of occurrence $99.634 \%$ \\
\hline${ }^{15} \mathrm{~N}$ & Stable N isotope, frequency of occurrence $0.366 \%$ \\
\hline $\mathrm{N}_{2}$ & Dinitrogen \\
\hline $\mathrm{N}_{\mathrm{t}}$ & Total soil nitrogen \\
\hline $\mathrm{Na}$ & Sodium \\
\hline $\mathrm{NH}_{4}^{+}$ & Amonium \\
\hline $\mathrm{NH}_{4} \mathrm{Cl}$ & Amonium chloride \\
\hline
\end{tabular}




$\begin{array}{ll}\mathrm{NH}_{4} \mathrm{NO}_{3} & \text { Ammonium nitrate } \\ \mathrm{NO} & \text { Nitric oxide } \\ \mathrm{NO}_{2} & \text { Nitrogen dioxide } \\ \mathrm{NO}_{3}^{-} & \text {Nitrate } \\ \mathrm{N}_{2} \mathrm{O} & \text { Nitrous oxide } \\ \mathrm{NPK} & \text { Mineral fertilizer with nitrogen, phosphorus and potassium } \\ \mathrm{NRE} & \text { Nitrogen response efficiency } \\ \mathrm{NUE} & \text { Nitrogen use efficiency } \\ \mathrm{P} & \text { Phosphorus } \\ P & \text { Significance level } \\ \mathrm{PVC} & \text { Polyvinyl chloride } \\ \mathrm{R}^{2} & \text { Coefficient of determination } \\ \mathrm{SE} & \text { Standard error } \\ \text { TDN } & \text { Total dissolved nitrogen } \\ \text { UV } & \text { Ultraviolet } \\ \text { WFPS } & \text { Water filled pour space }\end{array}$




\section{SUMMARY}

Grasslands play an important role in land use, covering one third of the agriculturally utilized landscape in Europe. As a consequence of management intensification in the last 60 years, the productivity of grasslands increased and the diversity of these systems decreased. Nitrogen $(\mathrm{N})$ plays a key role in these ecosystems - it limits primary productivity and affects biodiversity. Increasing $\mathrm{N}$ supply may alter nitrous oxide $\left(\mathrm{N}_{2} \mathrm{O}\right)$ and nitric oxide $(\mathrm{NO})$ emissions, which play a major role in atmospheric chemistry and contribute to global warming. Nitrate $\left(\mathrm{NO}_{3}{ }^{-}\right)$leaching from soils can be a threat for groundwater quality. $\mathrm{N}$ losses of $\mathrm{N}_{2} \mathrm{O}$ and $\mathrm{NO}$ emissions and $\mathrm{NO}_{3}{ }^{-}$leaching from soils result from microbial processes denitrification and nitrification. In this study, we analyzed the effect of different management intensities and plant functional diversity on $\mathrm{N}$ losses and ecosystem functioning.

The study was carried out as part of the Cluster of Excellence "Functional Biodiversity Research" at the Georg-August-University of Göttingen and was funded by the State of Lower Saxony (Ministry of Science and Culture). The study was conducted in the framework of two interdisciplinary projects (BIOMIX \& GRASSMAN) from 2008 - 2010 in the Solling, in Lower Saxony, Germany. We analyzed a grassland grazed by cattle or sheep (BIOMIX) and a cut grassland with different management intensities (GRASSMAN). In both projects, functional plant diversity was influenced by the use of herbicides. Our particular focus was on $\mathrm{N}$ losses $\left(\mathrm{N}_{2} \mathrm{O}\right.$ and $\mathrm{NO}$ emissions, $\mathrm{N}$ leaching) and $\mathrm{N}$ dynamics (net and gross mineralization). Within GRASSMAN, we calculated $\mathrm{N}$ response efficiency and $\mathrm{N}$ retention efficiency on ecosystem-level. $\mathrm{N}$ response efficiency is defined as the product of uptake efficiency (defined as plant $\mathrm{N}$ uptake per unit of available $\mathrm{N}$ ) and $\mathrm{N}$ use efficiency (defined as productivity per unit of plant $\mathrm{N}$ uptake). In addition, we defined $\mathrm{N}$ retention efficiency as the soil available $\mathrm{N}$ retained in an ecosystem.

In BIOMIX, we investigated the response of $\mathrm{N}_{2} \mathrm{O}$ and $\mathrm{NO}$ emissions to different grazers and sward composition. Paddocks partly pretreated with a herbicide against dicots were grazed rotationally by either cattle or sheep. Mean $\mathrm{N}_{2} \mathrm{O}$ emissions were $38.7 \mu \mathrm{g} \mathrm{N}_{2} \mathrm{O}-\mathrm{N}$ $\mathrm{m}^{-2} \mathrm{~h}^{-1}$, mean NO emissions $2.4 \mu \mathrm{g}$ NO-N m${ }^{-2} \mathrm{~h}^{-1}$. Cumulative NO-N emissions were larger for sheep- than for cattle-grazed paddocks. In a controlled application experiment, plots with cattle excreta showed larger $\mathrm{N}_{2} \mathrm{O}$ emissions than plots with sheep excreta, reaching peak emissions of $1921 \mu \mathrm{g} \mathrm{N}_{2} \mathrm{O}-\mathrm{N} \mathrm{m}^{-2} \mathrm{~h}^{-1}$ on cattle urine patches compared to $556 \mu \mathrm{g} \mathrm{N}_{2} \mathrm{O}-\mathrm{N} \mathrm{m}^{-2} \mathrm{~h}^{-}$ 
${ }^{1}$ on sheep urine patches, related to different $\mathrm{N}$-inputs per excretion. Peak emissions of dungtreated plots were much smaller. The $\mathrm{N}_{2} \mathrm{O}$ emission factors were $0.4 \%$ for cattle urine, $0.5 \%$ for sheep urine, $0.05 \%$ for cattle dung and $0.09 \%$ for sheep dung. In the main and the controlled application experiment, plant species composition was insignificant compared to the effect of grazers on $\mathrm{N}$ oxide emissions. $\mathrm{N}$ oxide emissions on the paddock scale were larger for sheep- compared to cattle-grazing, despite larger emissions per cattle excretion. We attributed this to the more even spread of sheep excreta compared to cattle excreta.

In GRASSMAN, we investigated the effects of management practices (fertilizer application and mowing frequency) and sward composition on $\mathrm{N}$ losses $\left(\mathrm{N}_{2} \mathrm{O}\right.$ emissions, $\mathrm{N}$ leaching) and $\mathrm{N}$ dynamics (net and gross mineralization), and calculated $\mathrm{N}$ response efficiency and $\mathrm{N}$ retention efficiency. A three-factorial design was conducted, including two fertilization treatments $\left(180-30-100 \mathrm{~kg} \mathrm{NPK} \mathrm{ha}^{-1} \mathrm{yr}^{-1}\right.$ and no fertilization), two mowing frequencies (cut once and thrice per year) and three sward compositions (control, dicotenhanced and monocot-enhanced swards) over a two-year period. In 2009, $\mathrm{N}_{2} \mathrm{O}$ emissions were significantly influenced by both management practices (fertilization and mowing frequency). In 2010, only fertilization affected $\mathrm{N}_{2} \mathrm{O}$ emissions. In $2009, \mathrm{NO}_{3}$ leaching losses were influenced by fertilization and in 2010 by both management practices (fertilization and mowing frequency) influenced $\mathrm{NO}_{3}$ leaching. Net $\mathrm{N}$ mineralization rates were affected only by fertilizer application in 2009. In 2010, not only fertilization but also mowing frequency influenced net $\mathrm{N}$ mineralization rates. Neither management practices nor sward composition affected gross $\mathrm{N}$ mineralization. The $\mathrm{N}$ response efficiency was largely influenced by fertilization, followed by mowing frequency, explaining $41 \%$ and $3 \%$ of the variance, respectively, in 2009. In 2010, the effect of fertilization was lessened whereas the effects of mowing frequency and sward composition were more pronounced, accounting for $24 \%, 12 \%$ and $6 \%$ of the variance, respectively. The $\mathrm{N}$ response efficiency was larger in unfertilized than in fertilized plots, in plots cut thrice than once per year, and in control swards than in monocot- or dicot-enhanced swards. Fertilization decreased $\mathrm{N}$ response efficiency through decreases in both $\mathrm{N}$ uptake efficiency and $\mathrm{N}$ use efficiency whereas mowing frecuency and sward composition affected $\mathrm{N}$ response efficiency through $\mathrm{N}$ uptake efficiency rather than $\mathrm{N}$ use efficiency. $\mathrm{N}$ retention efficiency was calculated only for 2010 and was largely influenced by fertilization followed by sward composition explaining $22 \%$ und $17 \%$ of the variance, respectively. Unfertilized plots showed larger $\mathrm{N}$ retention efficiency than fertilized plots and $\mathrm{N}$ retention efficiency decreased in the order control > dicot-enhanced $>$ monocot- 
enhanced swards with a significant difference between control and monocot enhanced swards. $\mathrm{N}$ retention efficiency was highly correlated with microbial ammonium $\left(\mathrm{NH}_{4}{ }^{+}\right)$ immobilization and microbial biomass and only marginally correlated with plant $\mathrm{N}$ uptake, underlining the importance of microbial $\mathrm{N}$ retention in the soil-plant system.

Our results indicated that management practices are the most important factor determining ecosystem functioning in grassland. Fertilization, mowing frequency and livestock grazing largely influenced $\mathrm{N}$ response efficiency, $\mathrm{N}$ retention efficiency and $\mathrm{N}$ losses. The sward botanical composition had a minor effect on $\mathrm{N}$ cycling or efficiency. Control sward composition of $\sim 70 \%$ monocots and $\sim 30 \%$ dicots, resulting from extensive long-term management showed the largest efficiencies. Deviations from these proportions even to more balanced proportions of monocots and dicots - decreased efficiencies. N response efficiency and $\mathrm{N}$ retention efficiency are appropriate tools to evaluate environmental sustainability of sward compositions and management practices of grasslands. 


\section{ZUSAMMENFASSUNG}

Grünland spielt eine große Rolle in der Landnutzung und nimmt ein Drittel der landwirtschaftlich genutzten Fläche von Europa ein. Als Konsequenz der Intensivierung landwirtschaftlicher Bewirtschaftungsmaßnahmen der letzten 60 Jahre nahm die Produktivität des Grünlands zu während die Diversität dieser Systeme abnahm. In Grünland-Ökosystemen spielt Stickstoff $(\mathrm{N})$ eine Schlüsselrolle - N bedingt die Primärproduktion und beeinflusst die Biodiversität. Zudem kann eine steigende N-Verfügbarkeit gasförmige Emissionen, wie z.B. Distickstoffoxid $\left(\mathrm{N}_{2} \mathrm{O}\right)$ und Stickstoffmonoxid (NO) fördern, die eine große Rolle in der Atmosphäre spielen und zur globalen Erwärmung beitragen. Eine höhere Nitratauswaschung $\left(\mathrm{NO}_{3}{ }^{-}\right)$aus Böden kann eine Gefahr für die Grundwasserqualität sein. N-Verluste durch Ausgasung von $\mathrm{N}_{2} \mathrm{O}$ und $\mathrm{NO}$ sowie $\mathrm{NO}_{3}^{-}$-Auswaschung sind dabei die Folgen der mikrobiellen Prozesse Denitrifikation und Nitrifikation. In dieser Studie haben wir den Effekt von unterschiedlichen Bewirtschaftungsintensitäten und funktioneller Pflanzendiversität auf die N-Verluste und Ökosystemfunktionen untersucht.

Die Studie ist Teil des Excellenzclusters „Funktionelle Biodiversitätsforschung“ der Georg-August-Universität Göttingen und wurde durch das Niedersächsische Ministerium für Wissenschaft und Kultur finanziert. Die Studie wurde im Rahmen von zwei interdisziplinären Projekten (BIOMIX \& GRASSMAN) von 2008 bis 2010 im Solling, Niedersachsen, Deutschland durchgeführt. Wir untersuchten von Rindern und Schafen beweidetes Grünland (BIOMIX) und gemähtes Grünland mit unterschiedlichen Bewirtschaftungsintensitäten (GRASSMAN). In beiden Projekten wurde die funktionelle Pflanzendiversität durch Herbizide eingestellt. Der Fokus unserer Arbeit lag auf den N-Verlusten $\left(\mathrm{N}_{2} \mathrm{O}\right.$ and NO Emissionen, $\mathrm{NO}_{3}{ }^{-}$-Auswaschung) und der $\mathrm{N}$ Dynamik (Netto und Brutto Mineralisation). In GRASSMAN berechneten wir zusätzlich die N-Nutzungseffizienz und die NRückhalteeffizienz auf Ökosystemebene. Dabei ist die N-Nutzungseffizienz das Produkt der Aufnahmeeffizienz (definiert als N-Aufnahme der Pflanze pro verfügbares $\mathrm{N}$ ) und der $\mathrm{N}$ Nutzungseffizienz auf Pflanzenebene (definiert als Produktivität pro N-Aufnahme der Pflanze). Darüber hinaus berechnen wir N-Rückhalteeffizienz in Böden als einen Index, der das Verhältnis von N-Verlusten zu dem im Grünland verbleibenden N beschreibt.

In BIOMIX haben wir die Auswirkung von Beweidung und Pflanzenartenzusammensetzung auf $\mathrm{N}_{2} \mathrm{O}$ and $\mathrm{NO}$ Emissionen untersucht. Die mit einem Herbizid gegen Dikotyle vorbehandelten Weiden wurden mit Rindern oder Schafen Rotationsweise beweidet. 
Mittlere $\mathrm{N}_{2} \mathrm{O}$ Emissionen lagen bei $38.7 \mu \mathrm{g} \mathrm{N} \mathrm{N}_{2} \mathrm{O}-\mathrm{N} \mathrm{m}^{-2} \mathrm{~h}^{-1}$, mittlere NO Emissionen betrugen $2.4 \mu \mathrm{g}$ NO-N m${ }^{-2} \mathrm{~h}^{-1}$. Kumulative NO-N Emissionen waren höher auf den von Schafen beweideten Flächen als auf den von Rindern beweideten Flächen. In einem kontrollierten Applikations-Experiment führte die Behandlung mit Rinderurin zu höheren $\mathrm{N}_{2} \mathrm{O}$ Emissionen als die Behandlung mit Schafurin. Die Emissionshöchstwerte von $1921 \mu \mathrm{g} \mathrm{N}_{2} \mathrm{O}-\mathrm{N} \mathrm{m}^{-2} \mathrm{~h}^{-1}$ bei Behandlung mit Rinderurin im Vergleich zu $556 \mu \mathrm{g} \mathrm{N} \mathrm{N}_{2} \mathrm{O}-\mathrm{N} \mathrm{m}^{-2} \mathrm{~h}^{-1}$ bei Schafurin standen im Zusammenhang mit unterschiedlichen N-Einträgen pro Ausscheidung der Tiere. Die Emissionshöchstwerte der mit Dung behandelten Flächen waren im Vergleich mit den jeweiligen Urinbehandlungen viel geringer. Die $\mathrm{N}_{2} \mathrm{O}$ Emissionsfaktoren betrugen $0.4 \%$ für Rinderurin, 0.5\% für Schafurin, 0.05\% für Rinderdung und 0.09\% für Schafdung. Sowohl das Beweidungs-Experiment, als auch das kontrollierte Applikations-Experiment zeigten, dass die Pflanzenartenzusammensetzung auf N-Emissionen im Vergleich zum Einfluss der Weidetierart auf N-Emissionen unbedeutend war. Trotz höherer N-Einträge auf Rinderweiden waren die N-Emissionen aus der Schafbeweidung höher. Wir führten dies auf die gleichmäßigere Verteilung von Schafs-Exkrementen im Vergleich zu RindernExkrementen zurück.

In GRASSMAN untersuchten wir die Auswirkungen von unterschiedlichen Bewirtschaftungsregimen (Düngung und Schnittintensität) und Pflanzenartenzusammensetzung auf die N-Verluste $\left(\mathrm{N}_{2} \mathrm{O}\right.$ Emissionen, $\mathrm{NO}_{3}{ }^{-}$Auswaschung) und die $\mathrm{N}$ Dynamik (Netto und Brutto Mineralisation) und kalkulierten die N-Nutzungseffizienz und die N-Rückhalteeffizienz. Ein dreifaktorielles Design mit folgenden Faktoren wurde über einen Zeitraum von zwei Jahren etabliert: Düngung (180 - 30 - $100 \mathrm{~kg} \mathrm{NPK} \mathrm{ha}^{-1} \mathrm{yr}^{-1}$ und keine Düngung), Schnittintensität (ein- und dreimal pro Jahr) und Pflanzenartenzusammensetzung (eine unbehandelte Kontrolle, eine Dikotyl-erhöhte und eine Monokotyl-erhöhte Grasnarbe). In 2009 wurden die $\mathrm{N}_{2} \mathrm{O}$ Emissionen erheblich von beiden Bewirtschaftungsfaktoren (Düngung und Schnittintensität) beeinflusst, während in 2010 nur die Düngung die $\mathrm{N}_{2} \mathrm{O}$ Emissionen beeinflusste. In 2009 wurden $\mathrm{NO}_{3}{ }^{-}$Auswaschungsverluste durch Düngung und in 2010 von beiden Bewirtschaftungsfaktoren (Düngung und Schnittintensität) beeinflusst. Die Netto N-Mineralisation Raten wurden in 2009 nur von der Düngung beeinflusst. In 2010, zeigte nicht nur die Düngung, sondern auch die Schnittintensität einen Einfluss auf die Netto N-Mineralisation Raten. Weder die Bewirtschaftung (Düngung) noch die Pflanzenartenzusammensetzung hatte einen Einfluss auf die Brutto N-Mineralisation. Die NNutzungseffizienz wurde vor allem durch die Düngung und als weiterer Faktor durch die 
Schnittintensität in 2009 beeinflusst, welche $41 \%$ bzw. 3\% der Varianz erklärten. In 2010 hatte die Düngung mit 24\% der erklärten Varianz einen geringeren Effekt auf die NNutzungseffizienz, während die Auswirkungen der Schnittintensität (12\%) und die Pflanzenartenzusammensetzung (6\%) stärker ausgeprägt waren. Die N-Nutzungseffizienz war auf ungedüngten Flächen größer als auf gedüngten, in den dreimal geschnittenen Flächen höher als in den einmal geschnittenen, und in der unbehandelten Kontrolle höher als in der Monokotyl-erhöhte oder Dikotyl-erhöhte Grasnarbe. Düngung verringert die NNutzungseffizienz durch die Abnahme in der N-Aufnahmeeffizienz und der $\mathrm{N}$ Nutzungseffizienz auf Pflanzenebene, während die Schnittintensität und die Pflanzenartenzusammensetzung nur durch die N-Aufnahmeeffizienz beeinflusst werden. Die N-Rückhalteeffizienz wurde nur für 2010 berechnet und wurde durch die Düngung und die Pflanzenartenzusammensetzung mit $22 \%$ und $17 \%$ der erklärten Varianz beeinflusst. NRückhalteeffizienz nahm in der Reihenfolge unbehandelte Kontrolle > Dikotyl-erhöhte > Monokotyl-erhöhte Grasnarbe mit einem signifikanten Unterschied zwischen der unbehandelten Kontrolle und der Monokotyl-erhöhten Grasnarbe ab. Die NRückhalteeffizienz ist mit dem mikrobiellen Ammonium $\left(\mathrm{NH}_{4}{ }^{+}\right)$und der mikrobiellen Biomasse hoch und mit der N-Aufnahme der Pflanzen nur gering korreliert, was die Bedeutung der mikrobiellen N Retention im System Boden-Pflanze unterstreicht.

Unsere Ergebnisse zeigen, dass die Bewirtschaftung der wichtigste und bestimmende Faktor der Ökosystemfunktionen eines Grünlands ist. Düngung, Schnittintensität und Beweidung beeinflussen die N-Nutzungseffizienz, die N-Rückhalteeffizienz und die NVerluste. Die Zusammensetzung der botanischen Grasnarbe hat einen geringen Einfluss auf den $\mathrm{N}$ Kreislauf oder die N-Nutzungs- und die N-Rückhalteeffizienz. Wobei die Pflanzenartenzusammensetzung der unbehandelten Kontrolle ( 70\% Monokotyle und $30 \%$ Dikotyle), die sich unter der extensiven Langzeit-Bewirtschaftung eingestellt hatte, die höchsten Effizienzen zeigte - sowohl eine Erhöhung der Monokotyledonen als auch eine Erhöhung der Dikotyledonen führte zu einer Verringerung der Effizienzen. Darüber hinaus sind N-Nutzungs- und N-Rückhalteeffizienz geeignete Werkzeuge, die sich zur Evaluierung ökologischer Nachhaltigkeit von Pflanzenartenzusammensetzungen und ManagementPraktiken im Grünland eignen. 


\section{CHAPTER}

1

\section{GENERAL INTRODUCTION}




\subsection{TEMPERATE GRASSLANDS - MANAGEMENT AND BIODIVERSITY}

Grasslands play an important role in the land use of the European Union (EU), covering more than $30 \%$ of the agriculturally utilized landscape (EUROSTAT, 2001). However, the distribution of natural European grassland is restricted to marshlands close to the coast, very dry and very wet ecosystems in the lowlands and to above the timberline in mountainous ecosystems. Since the Middle Ages, the human population increased and forests have been cleared and replaced by grassland and arable land (Ellenberg and Leuschner, 2010). In the $20^{\text {th }}$ century, also semi-natural grassland was utilized agriculturally and the management was intensified by increasing mowing frequency, grazing pressure and fertilization. Grassland management shifted from extensive grazing and mowing regimes of one cut $\mathrm{yr}^{-1}$ to intensive grazing and mowing with three to six cuts $\mathrm{yr}^{-1}$. Fertilization has been increased from no or low fertilization rates to amounts of $150-300 \mathrm{~kg} \mathrm{~N} \mathrm{ha}^{-1} \mathrm{yr}^{-1}$. As a result, semi-natural grassland ecosystems were replaced by pastures and meadows or arable land where the soil was very fertile and non-profitable grassland on low fertile soils became abandoned (Isselstein et al., 2005; Krahulec et al., 2001; Tasser and Tappeiner, 2002; Vitousek et al., 1997).

Permanent grassland makes an important contribution to plant diversity (Nösberger and Rodriguez, 1996). More diverse grassland systems have a large potential in increasing the productivity and the sustainability of ecosystem services and might be advantageous compared to simplified or less species-rich communities under the conditions of climate change: Hector et al. (1999) and Naeem et al. (1994) showed that more diverse grasslands can be more productive than less diverse grasslands. Agricultural intensification in European grasslands is one of the main factors for biodiversity decline (Tscharntke et al., 2005). Grassland is managed intensively or transferred into cropland. As a result, semi-natural grassland were replaced by agriculturally grasslands with a low plant and animal diversity (Fuller, 1987; Green, 1990; Poschlod and Bonn, 1998). A large-scale vegetation survey done by Krause et al. (2011) and Wesche et al. (2009) indicated that mesic and wet grasslands in Central Europe lost $30-50 \%$ of its plant species richness since the mid $20^{\text {th }}$ century due to changes in land use.

Biodiversity and ecosystem services in grassland have received an increasing attention. Therefore, grassland ecosystems are intensively studied. Most of the studies have 
so far been carried out in experimental grassland plots, sown and weeded intensively (Hector et al., 1999; Naeem et al., 1994; Tilman et al., 1996), making the results difficult to transfer to permanent grassland (Caliman et al., 2010; Petersen et al., 2012). Initiated in 2006 and 2008, the BIOMIX experiment and the GRASSMAN experiment aim to fill this knowledge gaps. Within these two experiments an untreated control sward was compared with herbicides treated swards. The swards received management treatments differing in grazing animals (BIOMIX) and in cutting frequency and fertilization (GRASSMAN).

\subsection{NITROGEN IN TEMPERATE GRASSLAND ECOSYSTEMS}

Nitrogen $(\mathrm{N})$ is an essential plant nutrient that limits primary production in many ecosystems, making requirement for $\mathrm{N}$ fertilizers pervasive in agricultural systems (Vitousek and Howarth, 1991). The Haber-Bosch process was the key invention in the $20^{\text {th }}$ century, which enabled the conversion of $\mathrm{N}_{2}$ into reactive $\mathrm{N}$ and thus the industrial production of mineral $\mathrm{N}$ fertilizer (Gruber and Galloway, 2008). A large proportion of applied fertilizer $\mathrm{N}$ can be lost via emissions of nitrous oxides $\left(\mathrm{N}_{2} \mathrm{O}\right)$ and nitric oxide $(\mathrm{NO})$ or nitrate $\left(\mathrm{NO}_{3}{ }^{-}\right)$ leaching. These $\mathrm{N}$ losses from soils result from the microbial processes denitrification and nitrification (Firestone and Davidson, 1989). $\mathrm{N}_{2} \mathrm{O}$ is an important greenhouse gas contributing to global warming and the depletion of stratospheric ozone (Mosier et al., 1996; Schlesinger, 2009). It has a global warming potential that is 298 times larger than that of carbon dioxide $\left(\mathrm{CO}_{2}\right)$ and its concentration increased from 270 parts per billion (ppb) during the pre-industrial period to $319 \mathrm{ppb}$ in 2005 (IPCC, 2007). The main sink of $\mathrm{N}_{2} \mathrm{O}$ in the stratosphere is its destruction to highly reactive NO, which plays a crucial role regulating troposphere ozone concentrations (Crutzen, 1979). $\mathrm{NO}_{3}{ }^{-}$is the dominant form of $\mathrm{N}$ leached from soil in temperate systems. Most soils are negatively charged; therefore ammonium $\left(\mathrm{NH}_{4}{ }^{+}\right)$concentrations are usually small due to a fast conversion into $\mathrm{NO}_{3}{ }^{-}$. Leaching of $\mathrm{NO}_{3}{ }^{-}$ can be a threat for groundwater quality. Taken up with drinking water, $\mathrm{NO}_{3}{ }^{-}$can be harmful to human health by causing methemoglobinemia (blue-baby syndrome) (Di and Cameron, 2002). To protect humans, the European Union (EC Directive on Drinking Water 80/788) threshold value for drinking water is $50 \mathrm{mg} \mathrm{NO}_{3}{ }^{-} \mathrm{L}^{-1}$. Furthermore, $\mathrm{NO}_{3}{ }^{-}$leaching can cause eutrophication of surface waters (Di and Cameron, 2002; Howarth, 1988). 
As a consequence of the increasing global population, a more intensive agricultural production and therewith increasing use of $\mathrm{N}$ fertilizers can be expected for the future (Galloway et al., 2008). Beside (mineral) fertilizer application, a main source of $\mathrm{N}$ losses results from livestock management systems (Davidson, 2009). Urine and dung patches in pastures have been identified as potential hotspots for $\mathrm{N}$ losses from soils (Ma et al., 2006). There are $\mathrm{N}$ transformation characteristics for excreta patches of different pasture animals, depending on the excreta-covered area and the $\mathrm{N}$ concentration (Ma et al., 2006; Williams and Haynes, 1994). Cattle excreta patches are larger than those of sheep (Bolan et al., 2004). However, sheep urinate more frequently than cattle and their urine is more evenly spread in smaller, less concentrated patches than cattle urine (Williams and Haynes, 1994). It will be necessary to comprise $\mathrm{N}$ losses in pastures and meadows, keeping theses losses as small as possible and ensuring soil fertility and high productivity at the same time.

$\mathrm{N}$ response efficiency, as a measure of ecosystem functioning, integrates biomass production and $\mathrm{N}$ retention (Hiremath and Ewel, 2001). $\mathrm{N}$ response efficiency is calculated as the product of uptake efficiency (defined as plant $\mathrm{N}$ uptake per unit of available $\mathrm{N}$ ) and $\mathrm{N}$ use efficiency (NUE, defined as productivity per unit of plant $\mathrm{N}$ uptake) (Pastor and Bridgham, 1999). Experimental studies showed that the addition of species can lead to more productivity (Hector et al., 1999; Hooper and Vitousek, 1998; Naeem et al., 1994) and that greater diversity can lead to greater N retention (Tilman et al., 1996). Since increasing N response efficiency indicated increasing productivity and the associated retention of available $\mathrm{N}$ in plants, $\mathrm{N}$ response efficiency thus conversely signifies how much of available $\mathrm{N}$ may be lost, e.g. through gaseous $\mathrm{N}$ emissions and $\mathrm{N}$ leaching. In addition, we calculated $\mathrm{N}$ retention efficiency from soils as an index that describes the ratio of $\mathrm{N}$ losses $\left(\mathrm{N}_{2} \mathrm{O}\right.$ and $\left.\mathrm{NO}_{3}{ }^{-}\right)$to the $\mathrm{N}$ retained in the grassland. 


\subsection{EXPERIMENTAL SITES}

The study sites were located in the Solling Mountains, Lower Saxony, in Germany (Figure 1.1).
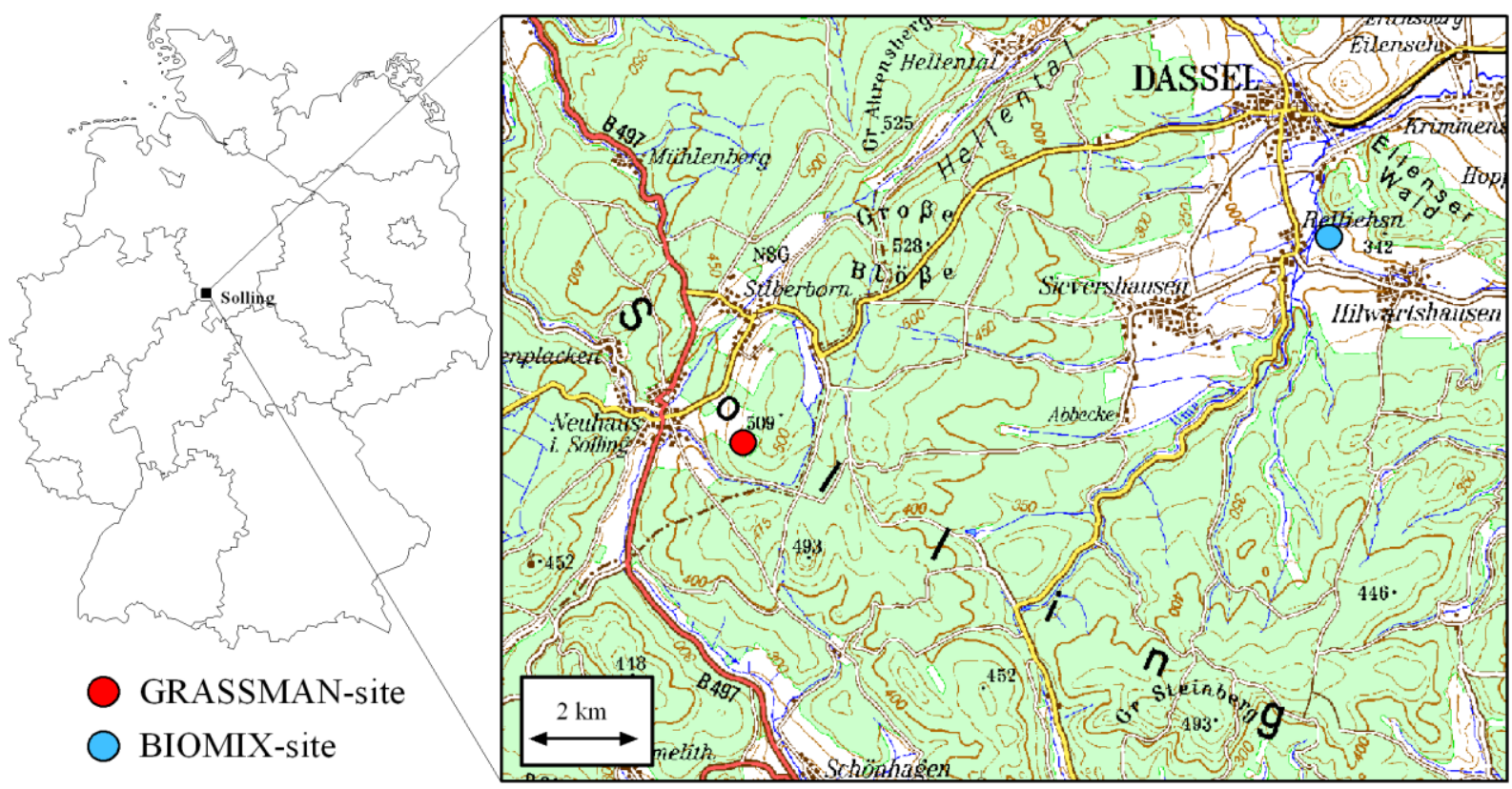

Figure 1.1 Location of the BIOMIX and GRASSMAN study sites in the Solling Mountains, Lower Saxony, Germany.

\subsubsection{THE BIOMIX PROJECT}

The BIOMIX pasture project was established in 2006 at the experimental farm of the University of Goettingen in Relliehausen in the Solling Mountains, Germany (51 ${ }^{\circ} 46^{\prime} 47^{\prime}$ 'N, 9 $42^{\prime} 11^{\prime \prime} \mathrm{E}, 184-209 \mathrm{~m}$ a.s.1.). Mean annual temperature is $8.2^{\circ} \mathrm{C}$ and the mean annual precipitation is $879 \mathrm{~mm}$ (Sahin Demirbag et al., 2009). The dominating soil type is a Cambisol with vertic properties developed on sediments of the Lower Triassic sandstone formation with a clay loam texture. The grassland is a 16-20 year old mesotrophic hill grassland with high productivity and moderate levels of plant diversity and is classified as a moderately species-rich Lolio-Cynosuretum (Seither, 2010). 


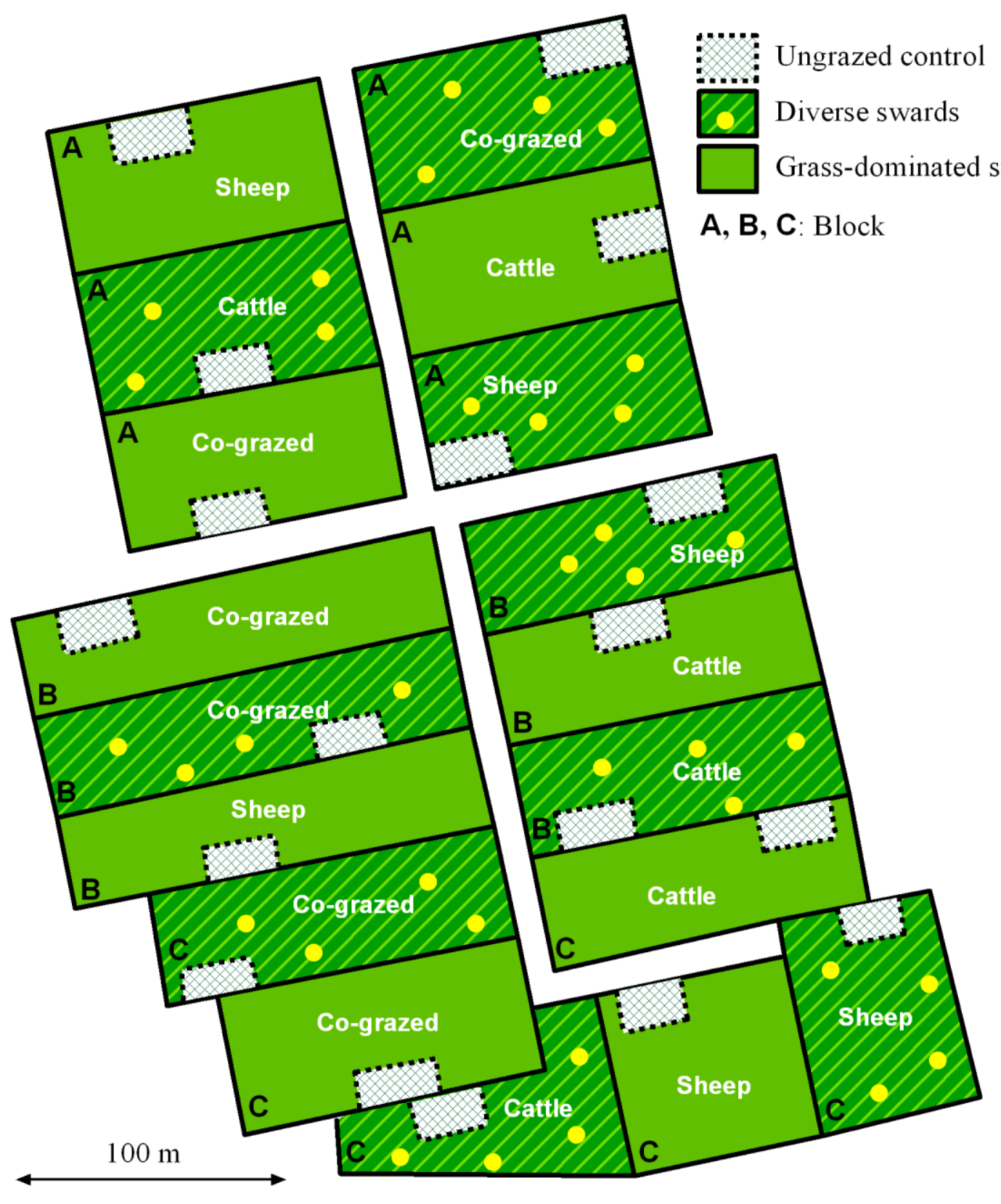

Figure 1.2 Experimental design of BIOMIX.

BIOMIX was established as a factorial experiment in a block design on 0.5 ha paddocks with three replicates presenting two sward compositions and two types of grazer (Figure 1.2). Differences in sward composition were established by applying a herbicide mixture against dicotyledons (Starane ${ }^{\circledR}$ (active ingredients: Fluroxypyr and Triclopyr) and Duplosan KV (active ingredient: Mecoprop P)), resulting in a sward dominated by grasses and an untreated control. The dominating plant species on grass swards after herbicide 
treatment were Dactylis glomerata L., Festuca pratensis Huds., Lolium perenne L., Phleum pratense L. and Poa trivialis L. On the untreated control, further dominant species were Crepis biennis L., Taraxacum Sec. ruderalia Kirschner, H. Ollg. \& Stepanek, and Trifolium repens L. (Seither, 2010). Both sward composition treatments were grazed either by sheep or cattle or mixed grazing. Suckler cows and calves of the breed German Simmental, and ewes with lambs of Blackheaded and Leine sheep were used as grazing animals. In our study, we only considered mono-grazed treatments with either cattle or sheep. The paddocks were grazed following a rotational scheme from spring to autumn. The average target animal live weight was $3000 \mathrm{~kg}$ (i.e. six livestock units of $500 \mathrm{~kg}$ each) in the first two rotations and was reduced to an average target animal live weight per paddock of $2000 \mathrm{~kg}$ in the third rotation. At the beginning of the grazing season (first two rotations), cattle and sheep stayed in one block for approximately 14 days, which was reduced to about seven days at the end of the grazing season (third rotation), because less vegetation biomass was available. In July, livestock was removed from the experiment for mating for six weeks. The study site received only $\mathrm{N}$ inputs from direct excreta returned by livestock without additional fertilization.

\subsubsection{THE GRASSMAN PROJECT}

The GRASSMAN project was established in 2008 at the experimental farm of the University of Goettingen on a moderately species rich grassland in the Solling Mountains in Lower Saxony, Germany (51 44'53'’N, 9³2’42’'E, $490 \mathrm{~m}$ a.s.1). Mean annual temperature is $6.9^{\circ} \mathrm{C}$ and mean annual precipitation is $1028 \mathrm{~mm}$ (Deutscher Wetterdienst 1961 - 1990). The dominating soil type is a Haplic Cambisol, developed on sediments of loess on the Middle Triassic sandstone formation with a loamy silt texture. The vegetation has been classified as a montane, semi-moist Lolio-Cynosuretum (Petersen et al., 2012). This permanent grassland site was used for hay making or for grazing throughout the $20^{\text {th }}$ century (Geological Map of Prussia 1910 (based on the topographic inventory of 1896), topographic maps of Sievershausen and Neuhaus/Solling 1924, 1956 and 1974). The study site was managed with moderate fertilization $\left(80 \mathrm{~kg} \mathrm{~N} \mathrm{ha}^{-1} \mathrm{yr}^{-1}\right)$, liming, overseeding with high value forage species and cattle grazing (farm records of Relliehausen since 1966) in the last five decades. Two years before the experiment started, fertilizer application stopped. 


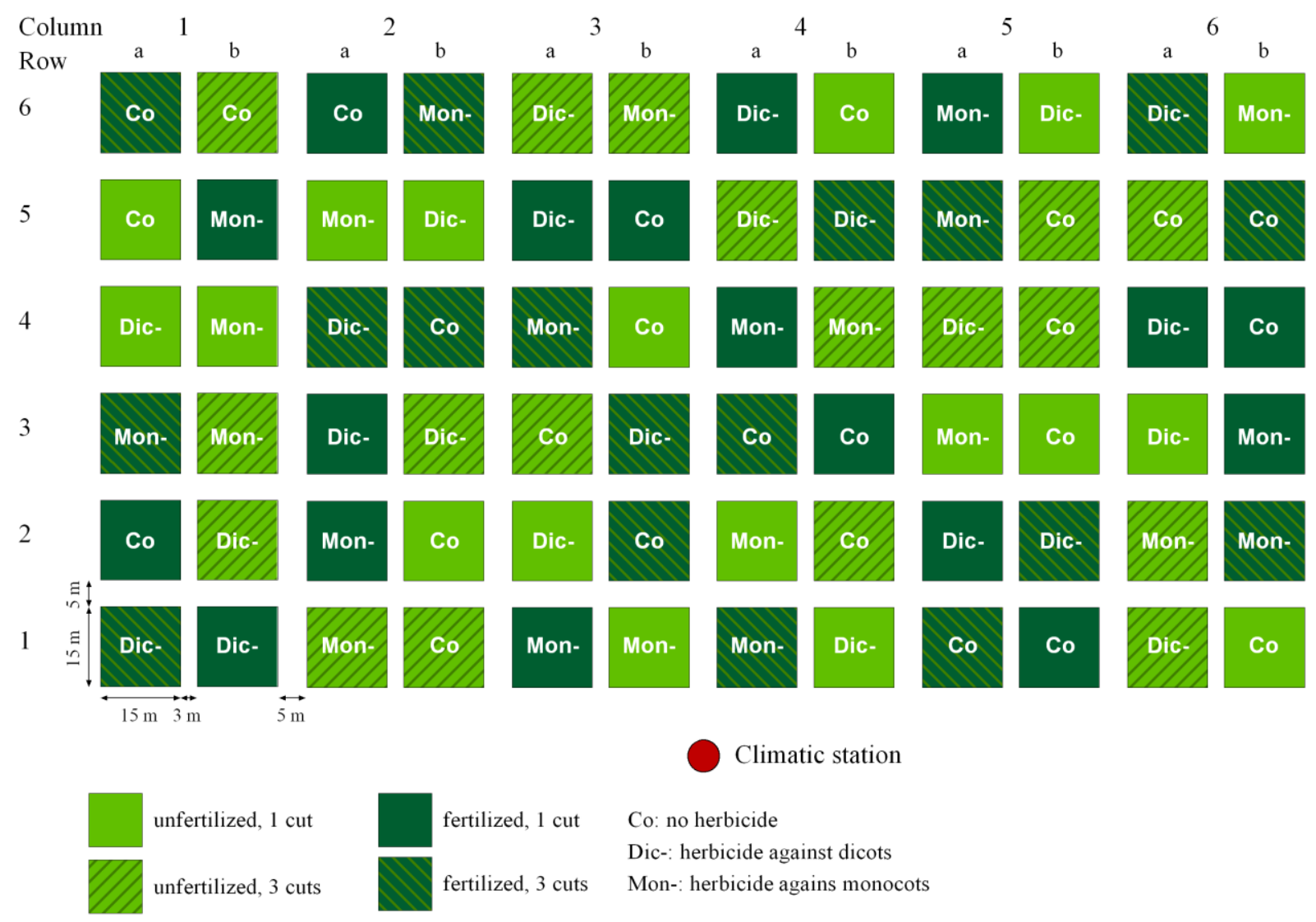

Figure 1.3 Experimental design of GRASSMAN.

Within the GRASSMAN experiment, 72 plots were arranged in a full factorial design with six replicate plots $(15 \mathrm{~m} \times 15 \mathrm{~m}$ each $)$ per treatment presenting three sward compositions, two mowing frequencies and two fertilization treatments arranged in a Latin rectangle (Figure 1.3). Differences in sward composition were associated with three plant functional groups. We established these three sward compositions by applying a herbicide mixture against dicotyledons (Starane ${ }^{\circledR}$ (active ingredients: Fluoroxypyr and Triclopyr) and Duplosan KV (active ingredients: Mecoprop-P®)) resulting in a sward with reduced herbs and legumes, a herbicide mixture against monocotyledons (Select 240 EC@ by Stähler (active ingredient: Clethodim)) resulting in a sward with reduced grasses, and an untreated control sward. Hereafter, we refer to these sward compositions as monocot-enhanced (12-13 species; 91-93\% grasses, 7-9\% herbs and 0\% legumes) and dicot-enhanced (17 species; 40$47 \%$ grasses, $49-53 \%$ herbs and 4-9\% legumes) and an untreated control sward (16-18 species; $68-76 \%$ grasses, $21-31 \%$ herbs and 1-4\% legumes) (Petersen et al., 2012). Two mowing frequencies (once and thrice per year) were established. Grassland was mown in 
mid-July for plots with one-cut per year and in mid-May, mid-July and end of September each year for plots with three-cuts per year. A Haldrup $(\subset$ forage combine harvester was used with a cutting height of $7 \mathrm{~cm}$. Two fertilization treatments $\left(180-30-100 \mathrm{~kg} \mathrm{NPK} \mathrm{ha}^{-1} \mathrm{yr}^{-1}\right.$ and no fertilization) were established. The $\mathrm{N}$ fertilizer (calcium ammonium nitrate N27) was split into two equal applications per year (April and May 2009 and April and June 2010) while the combined P and K fertilizer was applied once a year (June 2009 and 2010).

\subsection{METHODICAL OUTLINE OF NITROGEN LOSSES AND NITROGEN DYNAMICS}

\subsubsection{NiTROGEN LOSSES}

NO was measured using the open dynamic chamber method (Figure $1.4 \mathrm{a}$ ). NO was quantified with a Scintrex LMA-3 $\mathrm{NO}_{2}$ Analyzer with chemiluminescence detector following oxidation by $\mathrm{CrO}_{3}$ catalyst and reaction with a Luminol solution (Figure $1.4 \mathrm{~b}$ ). $\mathrm{N}_{2} \mathrm{O}$ was measured using closed chamber method during the growing season (Figure $1.4 \mathrm{c}$ ). The gas samples were analyzed using a gas chromatograph equipped with an electron capture detector and an autosampler system (Figure $1.4 \mathrm{~d}$ ). Additionally, for every gas sample, soil was sampled for determination of mineral $\mathrm{N}\left(\mathrm{NH}_{4}{ }^{+}\right.$and $\left.\mathrm{NO}_{3}{ }^{-}\right)$, soil moisture content and temperature.

$\mathrm{N}$ leaching losses $\left(\mathrm{NO}_{3}{ }^{-}\right.$and $\left.\mathrm{DON}\right)$ were measured using suction cups in a depth of 0.5-0.6 m. N concentrations were measured using continuous flow injection colorimetry. The total $\mathrm{N}$ leaching losses were calculated by multiplying the $\mathrm{NO}_{3}{ }^{-}$concentrations with the accumulated daily drainage flux for the corresponding time interval. Daily drainage flux was modelled using the 1D hydrological model BROOK90 (Federer et al., 2003). Additionally, driving climatic data (precipitation sum, minimum/maximum air temperature, global radiation sum, average vapour pressure and average wind speed, all on a daily basis) for the model came from a weather station of the study site. 

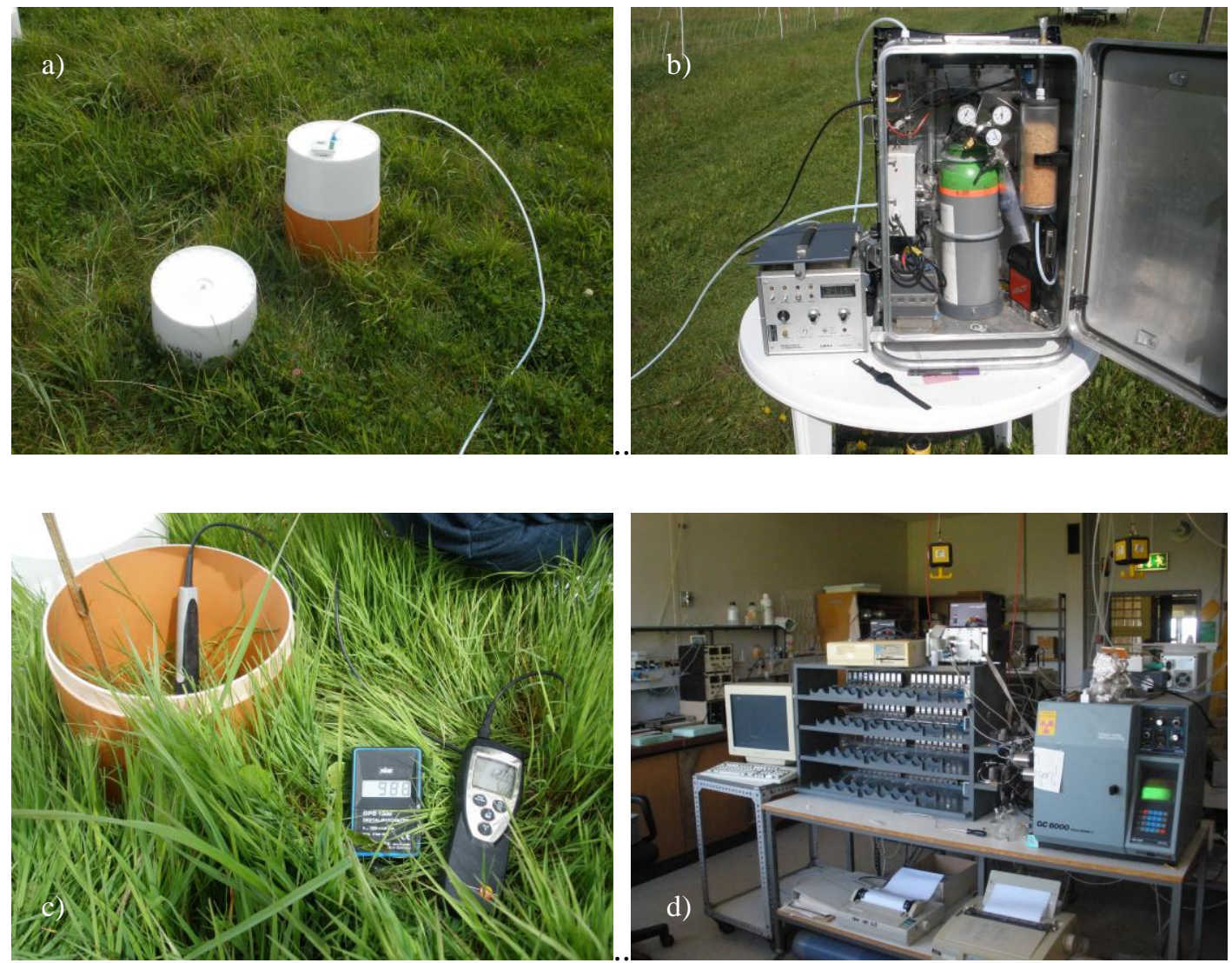

Figure 1.4 Field and laboratory equipment for soil trace gas measurements and analysis. a) Open dynamic chamber base and cover and b) $\mathrm{NO}_{2}$ detector and calibration gas for in situ nitric oxide (NO) flux measurements; c) closed chamber method for nitrous oxide $\left(\mathrm{N}_{2} \mathrm{O}\right)$ flux measurements and d) gas chromatograph (GC) with autosampler.

\subsubsection{NITROGEN DYNAMICS}

Net $\mathrm{N}$ mineralization rates were measured during the growing season using the buried bag method. Two intact soil cores were taken from the Ah mineral soil. The soil from one core was extruded into a plastic bag, mixed well, and extracted in $0.5 \mathrm{~mol} \mathrm{~L}^{-1} \mathrm{~K}_{2} \mathrm{SO}_{4}$ (average dry soil mass to solution ratio was 1:3). The other intact soil core was put in a plastic bag, loosely tied to permit aeration but prevent rain from entering, inserted back into the hole to incubate in-situ for ten days, and extracted in a similar manner. $\mathrm{NH}_{4}{ }^{+}$and $\mathrm{NO}_{3}{ }^{-}$were measured using continuous flow injection colorimetry. 
Gross mineralization rates of soil $\mathrm{N}$ cycling were measured directly in the field using ${ }^{15} \mathrm{~N}$-pool dilution technique. Two soil cores were injected with $\left({ }^{15} \mathrm{NH}_{4}\right)_{2} \mathrm{SO}_{4}$ solution (for gross mineralization) and two soil cores with $\mathrm{K}^{15} \mathrm{NO}_{3}$ solution (for gross nitrification) with $99 \%{ }^{15} \mathrm{~N}$ enrichment. After ${ }^{15} \mathrm{~N}$ injection one soil core of each labeled pair was broken up, mixed well in a plastic bag and $0.5 \mathrm{~mol} \mathrm{~L}^{-1} \mathrm{~K}_{2} \mathrm{SO}_{4}$ were added (average dry soil mass to solution ratio was 1:3). The other soil core of the labeled pair was put in a plastic bag, inserted back into the soil to incubate for one day, and extracted with $0.5 \mathrm{~mol} \mathrm{~L}^{-1} \mathrm{~K}_{2} \mathrm{SO}_{4} \cdot{ }^{15} \mathrm{~N}$ analysis was done using isotope ratio mass spectrometry.

\subsubsection{CALCUlation OF Nitrogen RESPONSE EFFICIENCY AND NITROGEN RETENTION EFFICIENCY}

Data of biomass yield was reported by From et al. (2011). A Haldrup (C) forage combine harvester was used with a cutting height of $7 \mathrm{~cm}$. Dry mass of the biomass was determined by oven-drying at $60{ }^{\circ} \mathrm{C}$ to constant mass. Oven-dried plant samples from the second cut (mid-July) were ground and analyzed for total $\mathrm{N}$ concentration using a CNS elemental analyser (Elementar Vario El, Hanau, Germany). Plant $\mathrm{N}$ uptake ( $\left.\mathrm{kg} \mathrm{N} \mathrm{ha}^{-1} \mathrm{yr}^{-1}\right)$ was calculated as: $\mathrm{N}$ concentration $\left(\mathrm{kg} \mathrm{N} \mathrm{kg}^{-1}\right) *$ biomass yield $\left(\mathrm{kg} \mathrm{ha}^{-1} \mathrm{yr}^{-1}\right)$ (Hiremath and Ewel, 2001).

$\mathrm{N}$ supply of each plot is defined as the sum of cumulative net $\mathrm{N}$ mineralization rates of the soil, $\mathrm{N}$ fertilization and $\mathrm{N}$ deposition rates. Cumulative net $\mathrm{N}$ mineralization rates during a growing season (i.e. April - September) were calculated by applying the trapezoid rule on time intervals between measured rates. For $\mathrm{N}$ deposition, we used a value of $12.6 \mathrm{~kg}$ $\mathrm{N} \mathrm{ha}^{-1} \mathrm{yr}^{-1}$ from bulk precipitation measured within the scope of the EU-level II monitoring program (Keuffel-Türk et al., in press). $\mathrm{N}$ response efficiency was calculated for each plot as follows: $\mathrm{N}$ response efficiency $\left(\mathrm{kg}\right.$ biomass $\left.\mathrm{kg} \mathrm{N}^{-1}\right)=($ plant $\mathrm{N}$ uptake $\div \mathrm{N}$ supply) $*$ (biomass yield $\div$ plant $\mathrm{N}$ uptake). The ratio of plant $\mathrm{N}$ uptake to $\mathrm{N}$ supply is referred to as $\mathrm{N}$ uptake efficiency whereas the ratio of biomass yield to plant $\mathrm{N}$ uptake is the $\mathrm{N}$ use efficiency (Hiremath and Ewel, 2001; Pastor and Bridgham, 1999).

$\mathrm{N}$ retention efficiency was calculated comprising plots with three sward compositions (monocot-enhanced, dicot-enhanced and control sward), two fertilization treatments (180 - 30 
- $100 \mathrm{~kg} \mathrm{NPK} \mathrm{ha}{ }^{-1} \mathrm{yr}^{-1}$ and no fertilization) and cut once per year, as follows: $\mathrm{N}$ retention efficiency $=1-\left(\left(\mathrm{N}\right.\right.$ losses $\left(\mathrm{mg} \mathrm{N} \mathrm{m}^{-2} \mathrm{~d}^{-1}\right) \div$ gross $\mathrm{N}$ mineralization rates $\left.\left(\mathrm{mg} \mathrm{N} \mathrm{m}^{-2} \mathrm{~d}^{-1}\right)\right)$ where $\mathrm{N}$ losses is composed of average daily $\mathrm{N}_{2} \mathrm{O}\left(\mathrm{mg} \mathrm{N} \mathrm{m}^{-2} \mathrm{~d}^{-1}\right)+\mathrm{NO}_{3}^{-}\left(\mathrm{mg} \mathrm{N} \mathrm{m}^{-2} \mathrm{~d}^{-1}\right)+$ DON ( $\mathrm{mg} \mathrm{N} \mathrm{m}^{-2} \mathrm{~d}^{-1}$ ); gross $\mathrm{N}$ mineralization rates were measured once during the growing season 2010.

\subsection{STUDY OBJECTIVES}

The aim of the present work was to investigate the soil $\mathrm{N}$ losses and soil $\mathrm{N}$ dynamics in a temperate pasture and a meadow differing in plant composition and management. The specific objectives of these studies were:

I. To investigate the response of soil $\mathrm{N}$ oxide $\left(\mathrm{N}_{2} \mathrm{O}\right.$ and $\left.\mathrm{NO}\right)$ emissions to grazer (cattle and sheep) and plant species composition in a pasture.

II. To investigate $\mathrm{N}$ response efficiency of a managed phytodiverse meadow.

III. To investigate $\mathrm{N}$ retention efficiency, soil $\mathrm{N}$ cycling and losses of a managed phytodiverse meadow.

With these aims I tested the following hypotheses:

BIOMIX:

1) On a paddock scale, sheep excreta result in larger $\mathrm{N}_{2} \mathrm{O}$ and $\mathrm{NO}$ emissions than cattle excreta.

2) Grasslands with a more diverse species composition have smaller $\mathrm{N}_{2} \mathrm{O}$ and $\mathrm{NO}$ emissions than grass-dominated paddocks.

GRASSMAN:

3) Unfertilized plots have larger $\mathrm{N}$ response efficiency than fertilized plots.

4) Plots with a high mowing frequency have larger $\mathrm{N}$ response efficiency than plots with a low mowing frequency.

5) $\mathrm{N}$ response efficiency increases with increasing number of species (i.e. monocotenhanced swards (12-13 species) < dicot-enhanced (17 species) and control swards (16-18 species)). 
6) Fertilization results to larger $\mathrm{N}$ losses and smaller $\mathrm{N}$ retention efficiency than without fertilization.

7) Intensive mowing frequency decreases $\mathrm{N}$ losses and increases $\mathrm{N}$ retention efficiency.

8) Swards with equal proportions of various plant functional groups would have small $\mathrm{N}$ losses and large $\mathrm{N}$ retention efficiency. 
CHAPTER

2

\section{RESPONSE OF NITROGEN OXIDE}

EMISSIONS TO GRAZER SPECIES AND

PLANT SPECIES COMPOSITION IN

TEMPERATE AGRICULTURAL

GRASSLAND 


\subsection{ABSTRACT}

Agriculture is an important source of the greenhouse gas nitrous oxide $\left(\mathrm{N}_{2} \mathrm{O}\right)$ and the atmospherically-important nitric oxide (NO). We evaluated the effects of different grazers and plant species composition on $\mathrm{N}_{2} \mathrm{O}$ and $\mathrm{NO}$ emissions in temperate grassland. Paddocks were grazed rotationally by either cattle or sheep. Mean $\mathrm{N}_{2} \mathrm{O}$ emissions were $38.7 \mu \mathrm{g} \mathrm{N} \mathrm{N}_{2} \mathrm{O}-\mathrm{N}$ $\mathrm{m}^{-2} \mathrm{~h}^{-1}$, mean NO emissions $2.4 \mu \mathrm{g}$ NO-N m${ }^{-2} \mathrm{~h}^{-1}$. Cumulative NO-N emissions were larger for sheep- than for cattle-grazed paddocks. Plant species composition was insignificant compared to the effect of grazers on $\mathrm{N}$ oxide emissions. In a controlled application experiment, plots with cattle excreta showed larger $\mathrm{N}_{2} \mathrm{O}$ emissions than plots with sheep excreta, reaching peak emissions of $1921 \mu \mathrm{g} \mathrm{N} \mathrm{N}_{2} \mathrm{O}-\mathrm{N} \mathrm{m}^{-2} \mathrm{~h}^{-1}$ on cattle urine patches compared to $556 \mu \mathrm{g} \mathrm{N}_{2} \mathrm{O}-\mathrm{N} \mathrm{m}^{-2} \mathrm{~h}^{-1}$ on sheep urine patches, related to different $\mathrm{N}$-inputs per excretion. Peak emissions of dung-treated plots were much smaller. The $\mathrm{N}_{2} \mathrm{O}$ emission factors were $0.4 \%$ for cattle urine, $0.5 \%$ for sheep urine, $0.05 \%$ for cattle dung and $0.09 \%$ for sheep dung. $\mathrm{N}$ oxide emissions on the paddock scale were larger for sheep-compared to cattle-grazing, despite larger emissions per cattle excretion. We attributed this to the more even spread of sheep excreta compared to cattle excreta.

Keywords: nitrous oxide, nitric oxide, trace gas fluxes, emission factor, dicots, monocots

\subsection{INTRODUCTION}

Nitrous oxide $\left(\mathrm{N}_{2} \mathrm{O}\right)$ is an important greenhouse gas that contributes about $6 \%$ to the anthropogenic greenhouse effect. It has a global warming potential that is 298 times larger than that of carbon dioxide $\left(\mathrm{CO}_{2}\right)$ and its concentration increased from 270 parts per billion (ppb) during the pre-industrial period to $319 \mathrm{ppb}$ in 2005 (IPCC, 2007). Agriculture is considered responsible for $58 \%$ of the anthropogenic $\mathrm{N}_{2} \mathrm{O}$ production (IPCC, 2007), with main sources from livestock management systems and from (mineral) fertilizer application (Davidson, 2009). $\mathrm{N}_{2} \mathrm{O}$ and nitric oxide (NO) emissions from soils result among other from the microbial processes denitrification and nitrification (Firestone and Davidson, 1989). 
These processes are mainly controlled by available $\mathrm{N}$ and soil aeration status, which depend on soil water-filled pore space (WFPS), and other drivers like soil temperature (Keeney et al., 1979; Linn and Doran, 1984).

Urine and dung patches in pastures have been identified as potential hotspots for $\mathrm{N}_{2} \mathrm{O}$ and NO emissions from soils, as large concentrations of $\mathrm{N}$, usually in excess of immediate plant requirements, are deposited onto a relatively small soil area (Ma et al., 2006). Urine-N is rapidly hydrolyzed and nitrified and the resulting large concentrations of inorganic $\mathrm{N}$ are a major source of $\mathrm{N}$ losses from grazed swards. In contrast, most $\mathrm{N}$ in dung is in organic form, and the mineral $\mathrm{N}$ contents in the soil and corresponding $\mathrm{N}$ losses are smaller than from urine patches (Flessa et al., 1996). Although several studies have been carried out to determine how cattle urine and dung influence $\mathrm{N}$ oxide emissions (e.g. Flessa et al., 1996; Van Groenigen et al., 2005), much fewer studies exist on $\mathrm{N}$ oxide emission responses to sheep urine or dung (Shand et al., 2002; Sherlock and Goh, 1983) or on direct comparisons of both cattle and sheep excreta (Williams and Haynes, 1994). The majority of these studies was conducted under controlled laboratory conditions (Van Groenigen et al., 2005) or with artificial urine (e.g. Carter, 2007). However, there is growing concern that results from studies using artificial rather than natural urine and from the laboratory may overestimate $\mathrm{N}$ oxide emissions (Van Groenigen et al., 2005). Nutrient dynamics of excreta patches depend on the area covered and on nutrient concentrations (Ma et al., 2006; Williams and Haynes, 1994). Cattle excreta patches are larger than those of sheep (Bolan et al., 2004). However, sheep urinate more frequently than cattle and their urine is more evenly spread in smaller, less concentrated patches than cattle urine (Williams and Haynes, 1994). Sampling directly on an excreta patch may lead to an underestimation of paddock-scale $\mathrm{N}$ oxide emissions of sheep compared to cattle grazing. In contrast, random sampling on the paddock may lead to an underestimation of $\mathrm{N}$ oxide emissions of cattle compared to sheep grazing, as excreta patches of cattle may be missed more often than those of sheep. Additionally, soil compaction in camping areas and overlapping of excreta patches may affect $\mathrm{N}_{2} \mathrm{O}$ emissions (Hack-ten Broeke et al., 1996; Van Groenigen et al., 2005). Beside the area influenced by excreta also the fodder or paddock size potentially affect $\mathrm{N}_{2} \mathrm{O}$ emissions (Oenema et al., 1997).

$\mathrm{N}$ losses may not only be affected by grazing but also by plant diversity. There are hints in literature that $\mathrm{N}$ losses decrease with increasing plant community composition (Niklaus et al., 2006). This is traced back to the impact of sward composition on nitrification and denitrification processes in grassland soils and an improved efficiency in the uptake of 
mineral $\mathrm{N}$ by more diverse sward communities (Niklaus et al., 2006; Oelmann et al., 2007). Differences in $\mathrm{N}_{2} \mathrm{O}$ and $\mathrm{NO}$ emissions between plots differing in sward composition may be due to interspecific discrepancies in productivity, growth rates, nutrient demands and mineral N-uptake efficiency of the distinct plant communities (Le Roux et al., 2003; Oelmann et al., 2007). Hence, more diverse swards may have a complementary and therefore overall more efficient resource use (Scherer-Lorenzen et al., 2003; Spehn et al., 2002), e.g. due to different rooting depths that enable the plants to take up nutrients from different soil horizons (Tilman et al., 1996). However, the more efficient uptake of mineral $\mathrm{N}$ in more diverse swards was due to plant communities dominated by legumes (Niklaus et al., 2006). Furthermore, most studies analyzing effects of plant diversity on soil nutrient dynamics have been carried out in artificial grassland plots. The short-term nature of these plots, missing agricultural management, as well as frequent weeding make the results difficult to compare with permanent agricultural grasslands (Caliman et al., 2010).

In the present study, our goal was to evaluate the effects of different grazers (cattle and sheep) and plant species composition on soil $\mathrm{N}$ cycling and related $\mathrm{N}_{2} \mathrm{O}$ and $\mathrm{NO}$ emissions in permanent, 16-20 year-old agricultural grassland. We tested the following hypotheses: 1) on a paddock scale, sheep excreta result in larger $\mathrm{N}_{2} \mathrm{O}$ and $\mathrm{NO}$ emissions than cattle excreta and 2) grasslands with a more diverse species composition have smaller $\mathrm{N}_{2} \mathrm{O}$ and $\mathrm{NO}$ emissions than grass-dominated paddocks. Measurements of soil $\mathrm{N}_{2} \mathrm{O}$ and $\mathrm{NO}$ emissions and supporting variables were performed throughout the grazing season on grassland differing in plant species composition due to herbicide treatment and managed according to local practices in the Solling uplands (Lower Saxony, Germany). To get a better understanding of the maximum $\mathrm{N}_{2} \mathrm{O}$ emissions on swards differing in species composition, we also applied cattle and sheep urine and dung manually in a controlled experiment at the same field site.

\subsection{MATERIAL AND METHODS}

\subsubsection{STUDY SITE}

Our experiment was conducted at the experimental farm of the University of Goettingen in Relliehausen in the Solling uplands, Germany (51 $46^{\prime} 47^{\prime}$ 'N, 9०42'11' 'E, 184209 m a.s.1.) on a moderately species-rich Lolio-Cynosuretum. The grassland is a 16-20 year 
old mesotrophic hill grassland with high productivity and moderate levels of plant diversity. The average annual precipitation is $879 \mathrm{~mm}$, the mean annual temperature $8.2^{\circ} \mathrm{C}$ (Sahin Demirbag et al., 2009). The dominating soil type is a Braunerde-Pelosol (FAO: cambisol with vertic properties) developed on sediments of the Lower Triassic sandstone formation with a clay loam texture.

\subsubsection{EXPERIMENTAL SETUP OF THE MAIN EXPERIMENT}

We established a factorial experiment in a block design on 0.5 ha paddocks in three replicates to evaluate grazer and sward composition effects on $\mathrm{N}$ cycling and related $\mathrm{N}$ oxide emissions. In autumn 2006, we established two sward compositions by applying a herbicide mixture against dicotyledons (Starane ${ }^{\circledR}$ (active ingredients: Fluroxypyr and Triclopyr) and Duplosan KV (active ingredient: Mecoprop P)), resulting in a sward dominated by grasses ('grass sward'; G) and an untreated control ('diverse sward'; D). After herbicide treatment, the dominating plant species on G were Dactylis glomerata L., Festuca pratensis Huds., Lolium perenne L., Phleum pratense L. and Poa trivialis L. On D, further dominant species were Crepis biennis L., Taraxacum Sec. ruderalia Kirschner, H. Ollg. \& Stepanek, and Trifolium repens L. (Seither, 2010). Both sward composition treatments were grazed either by sheep (S) or cattle (C). Grazing animals were suckler cows and calves of the breed German Simmental, and ewes and lambs of Blackheaded and Leine sheep in equal proportions. The average target animal live weight per paddock was $3000 \mathrm{~kg}$ (i.e. six livestock units of $500 \mathrm{~kg}$ each) in the first rotation and was reduced to an average target animal live weight per paddock of $2000 \mathrm{~kg}$ in the third rotation. The study site received only $\mathrm{N}$ inputs from direct excreta returned by livestock without additional fertilization. The experiment was grazed following a rotational scheme from spring to autumn (first, second and third rotation in 2008) and again in spring (fourth rotation 2009). Cattle and sheep stayed in one block for approximately 14 days at the beginning of the grazing season (first, second and fourth rotation), which was reduced to about seven days at the end (third rotation), because less vegetation biomass was available. No supplementary feeding took place while the animals were on the plots. In July, livestock was removed from the experiment for mating for six weeks. We conducted measurements of $\mathrm{N}$ oxide emissions, soil mineral $\mathrm{N}$ and WFPS shortly before and after grazing, following grazing periods from May to September 2008 and 
additionally for $\mathrm{N}_{2} \mathrm{O}$ emissions in May 2009 as explained below. Further investigations were done in early spring 2009 to catch a possible peak in $\mathrm{N}_{2} \mathrm{O}$ emissions during thawing, which we could not detect, however. Temperature and precipitation rate for the main experiment are shown in Figure 2.1 a.
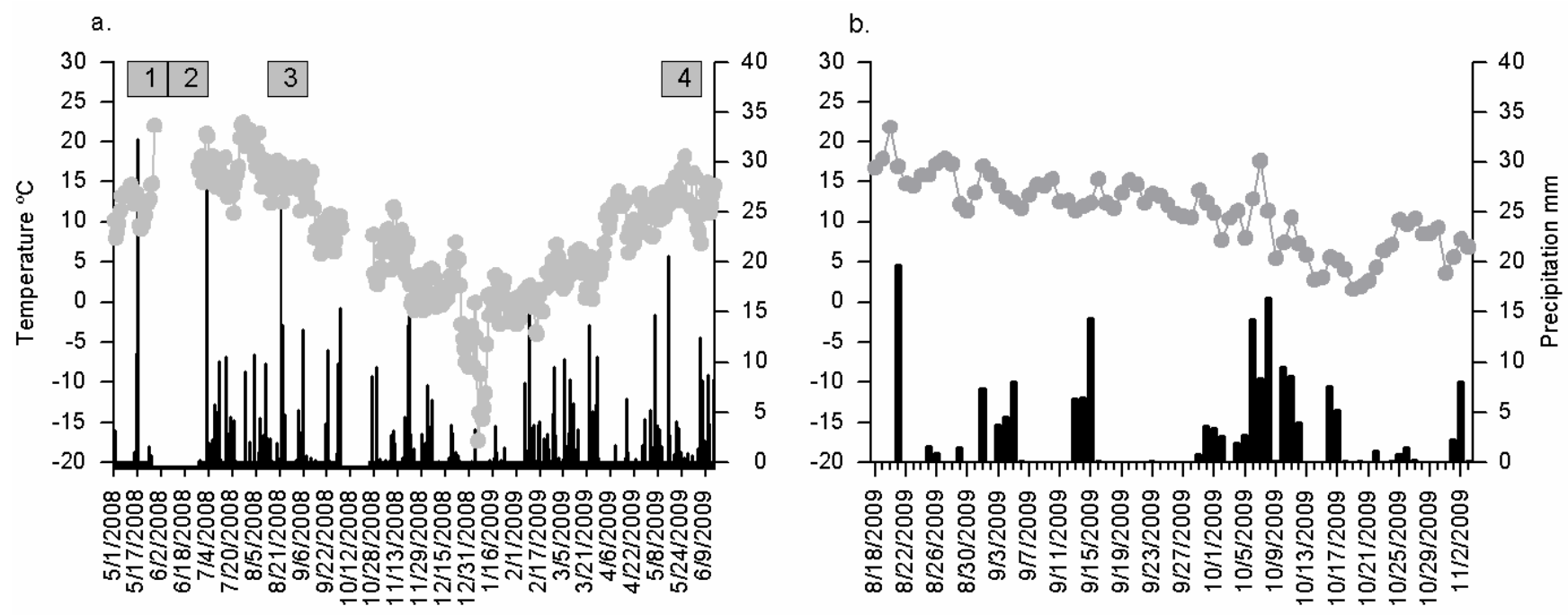

Figure 2.1 Daily air temperature in ${ }^{\circ} \mathrm{C}(\bullet)$ and precipitation rate in $\mathrm{mm}$ in black bars of a. the main experiment in 2008 and 2009 (1, 2, 3 and 4 showed the four grazing rotations) and b. the controlled application experiment in 2009 at a grassland site in the Solling uplands, Germany. Between May $29^{\text {th }}$ and June $26^{\text {th }}$, and the October $3^{\text {rd }}$ and October $26^{\text {th }} 2008$ the climate stations return no values.

\subsubsection{EXPERIMENTAL SETUP OF THE CONTROLLED APPLICATION EXPERIMENT}

In addition to the main experiment, we conducted a controlled application experiment on four exclosures of $4 \times 7 \mathrm{~m}^{2}$ established in July 2009 on the pastures described above. Within these exclosures, we applied urine and dung inside permanent chamber bases used for gas flux measurements: urine applied on grass sward/cattle grazed (GC-U), grass sward/sheep grazed (GS-U), diverse/cattle grazed (DC-U), diverse/sheep grazed (DS-U) and dung applied on grass sward/cattle grazed (GC-D), grass sward/sheep grazed (GS-D), diverse/cattle grazed (DC-D) and diverse/sheep grazed (DS-D). Furthermore, we established on GS and DS control exclosures without excreta application. Cattle urine was collected seven days before application from dairy cattle (German Simmental and German Holstein) at a dairy farm (tie- 
stall and extensive pasture). Sheep urine was collected five days before application from the Blackheaded and Leine sheep of the experiment. All samples were kept frozen at $-18^{\circ} \mathrm{C}$ until used. Fresh dung was collected from the paddocks on the day of application, pooled, mixed and applied within two hours of collection. We applied the amount of one urination or defecation within one chamber base. According to own observations and published work (Flessa et al., 1996), a cow produces around $1.5 \mathrm{~L}$ urination and $1.5 \mathrm{~kg}$ defecation per event, corresponding to $18 \mathrm{~g}$ urine-N $1.5 \mathrm{~L}^{-1}$ and $6 \mathrm{~g}$ dung-N $1.5 \mathrm{~kg}^{-1}$ (Table 2.1). A sheep produces on average $70 \mathrm{ml}$ urination and $60 \mathrm{~g}$ defecation per event (Ma et al., 2006), corresponding to $0.3 \mathrm{~g}$ urine-N $70 \mathrm{ml}^{-1}$ and $1 \mathrm{~g}$ dung-N $60 \mathrm{~g}^{-1}$ (Table 2.1). Urine-N was determined using continuous flow injection colorimetry (Cenco/Skalar Instruments, Breda, Netherlands) with a dilution of 1:100 to scale down large $\mathrm{NO}_{3}{ }^{-}$and $\mathrm{NH}_{4}{ }^{+}$peaks. $\mathrm{NH}_{4}{ }^{+}$was determined using the Berthelot reaction method (Skalar Method 155-000) and $\mathrm{NO}_{3}{ }^{-}$was measured using the copper-cadmium reduction method $\left(\mathrm{NH}_{4} \mathrm{Cl}\right.$ buffer without ethylenediamine tetraacetic acid; Skalar Method 461-000). Dung-N was determined after air-drying on a $\mathrm{C} / \mathrm{N}$ elemental analyzer (Vario MAX CN, Elementar, Hanau, Germany). The dry mass of dung was determined after air-drying to constant mass. Temperature and precipitation rate for the controlled application experiment are shown in Figure $2.1 \mathrm{~b}$.

Table 2.1 Set up of the controlled application experiment showing N-concentration, applied N per chamber base and dry matter content at a grassland site in the Solling uplands, Germany. For further explanations, see text.

\begin{tabular}{lcccc}
\hline & Cattle-urine & Sheep-urine & Cattle-dung & Sheep-dung \\
\cline { 2 - 5 } & & & & \\
\cline { 2 - 5 } N concentration $\left(\mathrm{g} \mathrm{N} \mathrm{L} \mathrm{L}^{-1}\right)$ & 12.2 & 3.88 & 19.4 & 16.7 \\
$\mathrm{~N}$ applied $\left(\mathrm{g} \mathrm{N} \mathrm{chamber}^{-1}\right)$ & 18.27 & 0.27 & 6.02 & 0.99 \\
Dry matter content $(\%)$ & - & - & 20.7 & 99.2 \\
\hline
\end{tabular}

\subsubsection{SOIL ANALYSES}

Soils were sampled in spring 2008 before the start of the grazing period and in summer 2009. At five sampling points per paddock, mineral soils (0-0.1 m depth) were sampled, oven-dried $\left(40^{\circ} \mathrm{C}\right)$ for a week and sieved $(2 \mathrm{~mm})$. Soil texture was determined by sedimentary fractionation of the clay fraction $\left(25^{\circ} \mathrm{C}, 21 \mathrm{~h}, 0.3 \mathrm{~m}\right.$ fall height) following the Atterberg method after separation of sand and silt fraction $(630 \mu \mathrm{m}, 200 \mu \mathrm{m}, 63 \mu \mathrm{m}, 36 \mu \mathrm{m}$ and $20 \mu \mathrm{m}$ ) by wet sieving and destruction of organic matter with $30 \% \mathrm{H}_{2} \mathrm{O}_{2}$ and $\mathrm{Fe}$ oxides 
with $4 \%$ Na-dithionite-citrate solution (Schlichting et al., 1995). Soil bulk density was determined in summer 2009 by the soil core method (Blake and Hartge, 1986), assuming a particle density of $2.65 \mathrm{~g} \mathrm{~cm}^{-3}$ for mineral soil (Linn and Doran, 1984). Soil $\mathrm{pH}$ was measured as $\mathrm{pH}_{(\mathrm{H} 2 \mathrm{O})}$. Soil samples were ground for analysis of total $\mathrm{C}$ and $\mathrm{N}$ on a $\mathrm{C} / \mathrm{N}$ elemental analyzer (Vario EL III, Elementar, Hanau, Germany). Soil characteristics are summarized in Table 2.2.

Table 2.2 Soil characteristics in the Ah horizon $(0-0.1 \mathrm{~m})$ of the treatments at a grassland site in the Solling uplands, Germany, sampled in spring 2008 and summer 2009.

\begin{tabular}{|c|c|c|c|c|c|}
\hline & $\mathrm{DC}$ & $\mathrm{DS}$ & GC & GS & $\begin{array}{c}\text { All } \\
\text { paddocks }\end{array}$ \\
\hline Sand $(\%)$ & & & & & $6.8 \pm 0.2$ \\
\hline Silt $(\%)$ & & & & & $54.4 \pm 1.5$ \\
\hline Clay $(\%)$ & & & & & $38.8 \pm 1.4$ \\
\hline Bulk density $\left(\mathrm{g} \mathrm{cm}^{-3}\right)^{*}$ & $1.3 \pm 0.1$ & $1.3 \pm 0.1$ & $1.3 \pm 0.1$ & $1.3 \pm 0.1$ & \\
\hline $\mathrm{pH}\left(\mathrm{H}_{2} \mathrm{O}\right){ }^{*}$ & $6.8 \pm 0.1$ & $6.4 \pm 0.2$ & $6.5 \pm 0.1$ & $6.8 \pm 0.1$ & \\
\hline Total carbon (C) $\left(\mathrm{mg} \mathrm{C} \mathrm{g}^{-1}\right)^{*}$ & $36.7 \pm 2.4$ & $32.6 \pm 4.7$ & $38.2 \pm 9.1$ & $34.3 \pm 3.8$ & \\
\hline Total nitrogen $(\mathrm{N})\left(\mathrm{mg} \mathrm{N} \mathrm{g}^{-1}\right)^{*}$ & $3.3 \pm 0.2$ & $3.3 \pm 0.4$ & $3.8 \pm 0.8$ & $3.3 \pm 0.3$ & \\
\hline $\mathrm{C} / \mathrm{N}^{*}$ & $12.7 \pm 0.6$ & $11.5 \pm 0.5$ & $11.5 \pm 0.4$ & $12 \pm 0.3$ & \\
\hline
\end{tabular}

DC: diverse/cattle grazed; DS: diverse/sheep grazed; GC: grass sward/ cattle grazed; GS: grass sward/sheep grazed

Means $( \pm \mathrm{SE}, \mathrm{n}=5)$ did not differ between treatments.

Soil chemical data were provided by the Department of Plant Ecology, University of Göttingen.

\subsubsection{N OXIDE MEASUREMENTS}

We used the closed chamber method for $\mathrm{N}_{2} \mathrm{O}$ flux measurements. In the main experiment, we inserted randomly three polyvinyl chloride (PVC) chamber bases $\left(0.04 \mathrm{~m}^{2}\right.$ area, 0.35-0.4 $\mathrm{m}$ height of chamber base and cover) in each paddock $0.02 \mathrm{~m}$ deep into the soil. For each measurement, the chamber base was covered with a PVC chamber hood fitted with a vent and an air sample port. Following chamber closure, gas samples were taken at 0 , 12,24 , and 36 minutes and stored in pre-evacuated glass containers (100 ml) with tefloncoated stopcocks. $\mathrm{N}_{2} \mathrm{O}$ was analyzed using a gas chromatograph (GC 6000, Carlo Erba Instruments/Thermo Fisher Scientific, Milan, Italy) equipped with an electron capture detector and an autosampler system (Loftfield et al., 1997). Gas concentrations were calculated by comparing integrated peak areas of samples with three standard gases (353, 1005, and $1592 \mathrm{ppb} \mathrm{N}_{2} \mathrm{O}$; Deuste Steiniger $\mathrm{GmbH}$, Mühlhausen, Germany). NO was quantified using the same three chamber bases as for $\mathrm{N}_{2} \mathrm{O}$ measurements with the open 
dynamic chamber method. Chambers were closed for five minutes and NO was quantified with a Scintrex LMA-3 $\mathrm{NO}_{2}$ Analyzer with chemiluminescence detector (Scintrex, Ontario, Canada) following oxidation by a $\mathrm{CrO}_{3}$ catalyst and reaction with a Luminol solution. The flow rate through the chamber was approximately $1.5 \mathrm{~L} \mathrm{~min}^{-1}$. The detector was calibrated using a standard gas (3000 ppb NO; Deuste Steiniger GmbH, Mühlhausen, Germany) diluted with make-up air to the range of concentrations measured in the field. Detector signal and time were recorded every ten seconds with a CR800 series data logger (Campbell Scientific, Utah, USA). We calculated N-oxide emissions ( $\mu \mathrm{g} \mathrm{N} \mathrm{m}^{-2} \mathrm{~h}^{-1}$ ) from the linear increase of gas concentration versus time for each chamber, corrected with air temperature, chamber volume and air pressure (Ruser et al., 1998). Cumulative $\mathrm{N}$ oxide rates $\left(\mathrm{kg} \mathrm{N} \mathrm{ha}{ }^{-1} 139 \mathrm{~d}^{-1}\right)$ were calculated by linear interpolation of the average $\mathrm{N}_{2} \mathrm{O}$ and $\mathrm{NO}$ emissions between the measurements and adding the results over the total time period.

In the controlled application experiment, we installed per exclosure three PVC chamber bases $\left(0.07 \mathrm{~m}^{2}\right.$ area, 0.35-0.4 $\mathrm{m}$ height $)$ three weeks before the first measurements. Chamber bases remained at the same location for the duration of the experiment. One pretreatment gas flux measurement was conducted on the day of application, prior to applying dung and urine. Immediately following application, another $\mathrm{N}_{2} \mathrm{O}$ flux measurement was done. Subsequent measurements were conducted daily during the first three days of the experiment. This was followed by two measurements per week and finally, during the last four weeks, weekly measurements. Gas sampling (taken at 0, 18, 36 and 54 minutes after chamber closure) and $\mathrm{N}_{2} \mathrm{O}$ analyses were conducted as described above. Cumulative excreta-derived $\mathrm{N}_{2} \mathrm{O}$ emissions $\left(\mathrm{kg} \mathrm{N}_{2} \mathrm{O}-\mathrm{N}_{\text {cum }} \mathrm{m}^{-2} 77 \mathrm{~d}^{-1}\right)$ were calculated by linear interpolation of the average $\mathrm{N}_{2} \mathrm{O}$ emissions $\left(\mathrm{N}_{2} \mathrm{O}-\mathrm{N}_{\text {emitted }}-\mathrm{N}_{2} \mathrm{O}-\mathrm{N}_{\text {control }}\right.$ in $\left.\mu \mathrm{g} \mathrm{N} \mathrm{m}{ }^{-2} \mathrm{~h}^{-1}\right)$ between the measurements and adding the results over the total time period. Emission factors (EF) were then calculated with Eq. 1, by using the arithmetic mean per treatment of the accumulated $\mathrm{N}_{2} \mathrm{O}$ emissions over the experimental time of 77 days.

$\mathrm{EF} \%=\left[\left(\mathrm{N}_{2} \mathrm{O}-\mathrm{N}_{\text {emitted }}-\mathrm{N}_{2} \mathrm{O}-\mathrm{N}_{\text {control }}\right) / \mathrm{N}\right.$ applied $] * 100$

Combining the data of the main and the controlled application experiment, we performed further calculations for the $\mathrm{N}$ input $\left(\mathrm{kg} \mathrm{N}_{\text {paddock }}{ }^{-1} \mathrm{~d}^{-1}\right)$ multiplying the number of cattle or sheep in a paddock with the frequency of urination or defecation per day, the amount and the $\mathrm{N}$ concentration of urine or dung per urination or defecation. The climatic conditions of both experiments were similar (Figure 2.1). For the duration of the controlled application 
experiment ( 77 days), the mean temperature was $10.7^{\circ} \mathrm{C}$ in 2008 and $11.2^{\circ} \mathrm{C}$ in 2009 , and the precipitation rate was $187.0 \mathrm{~mm}$ in 2008 and $178.5 \mathrm{~mm}$ in 2009 . The missing values for temperature and precipitation in 2008 were completed by a climate station nearby (Deutscher Wetterdienst). According to Williams and Haynes (1994), cattle urinate on average up to 11 times per day, while sheep urinate more frequently (18-20 times per day). Measurements of the soil surface area covered by urine (wetted area; measured by distribution of $\mathrm{Br}^{-}$as a urine tracer) range from 0.16 to $0.49 \mathrm{~m}^{2}$ for cattle and 0.03 to $0.05 \mathrm{~m}^{2}$ for sheep. Cattle excreta also cover a larger area than sheep excreta: The surface area of cattle dung patches is about 0.05 $0.09 \mathrm{~m}^{2}$, while that of sheep dung patches is about 0.008-0.025 $\mathrm{m}^{2}$ (Haynes and Williams, 1993; Williams and Haynes, 1994). For further calculations, we considered the mean value of all ranges for frequency and amount of urination and defacation as the basis for the upscaling on paddock size. Excreta-derived $\mathrm{N}_{2} \mathrm{O}$ emissions $\left(\mathrm{kg} \mathrm{N} \mathrm{N}_{2} \mathrm{O}-\mathrm{N}_{\text {emitt }}\right.$ paddock $\left.{ }^{-1} \mathrm{~d}^{-1}\right)$ were determined by using the EF per treatment multiplied with the calculated $\mathrm{N}$ input $(\mathrm{kg} \mathrm{N}$ paddock ${ }^{-1} \mathrm{~d}^{-1}$ ) on the paddock scale. Assuming an even and non-overlapping distribution of the single urine and dung patches, the area covered by excreta $\left(\mathrm{m}^{2}\right.$ paddock $\left.{ }^{-1} \mathrm{~d}^{-1}\right)$ was calculated by multiplying the number of cattle or sheep in a paddock with the frequency of urinations or defecations and the size of a urine or dung patch.

\subsubsection{SOIL MINERAL $N$}

We sampled soil cores (diameter $2.2 \mathrm{~cm} ; 0.1 \mathrm{~m}$ depth) at three points inside the chamber bases for the main experiment and at three supplementary patches each with either dung or urine application outside the chambers for the controlled application experiment. For the main experiment, soil for mineral $\mathrm{N}$ extraction was sampled during each $\mathrm{N}$ oxide measurement and for the controlled application experiment during every second measurement. Soil mineral $\mathrm{N}$ was determined from fresh soil samples $(50-60 \mathrm{~g})$ that were added to a $0.5 \mathrm{~mol} \mathrm{~L}^{-1} \mathrm{~K}_{2} \mathrm{SO}_{4}$ solution directly in the field and extracted after shaking for one hour in the laboratory. Soil extracts were filtered (Whatman 589/1) and stored at $-18^{\circ} \mathrm{C}$ in scintillation bottles. $\mathrm{NH}_{4}{ }^{+}$and $\mathrm{NO}_{3}^{-}$were measured using continuous flow injection colorimetry (Cenco/Skalar Instruments, Breda, Netherlands) as described before. Gravimetric moisture content was determined after drying at $105^{\circ} \mathrm{C}$ for 24 hours. Soil moisture content was expressed as WFPS. 


\subsubsection{STATISTICAL ANALYSIS}

For the main experiment, statistical analyses were carried out on $\mathrm{N}$ oxide emissions averaged over the three chambers per paddock. To test the effects of grazer and plant species composition in time series data $(\mathrm{N}$ oxide emissions and soil mineral $\mathrm{N}$ from rotational grazing), we conducted a linear mixed effects model (LME) with grazer and plant species composition as fixed effects and date and block as random effects. $\mathrm{N}$ oxide emissions and soil mineral $\mathrm{N}$ were square root transformed. As negative $\mathrm{N}$ oxide emissions were detected, we added a constant prior to square root transformations for statistics. To test for differences between treatments of distinct plant species composition or of different species of grazer on cumulative $\mathrm{N}$ oxide emissions, we used a $\mathrm{T}$ test. To test the effects of continuous variables (soil mineral N, WFPS, temperature) on the log-transformed $\mathrm{N}_{2} \mathrm{O} / \mathrm{NO}$ ratio, multiple linear regression analysis were carried out.

On the controlled application experiment, we were not able to measure true replicates. With a model of nested temporal pseudoreplicates, the temporal dynamics of the experiment was included into the analysis. As we assumed that "time" could have a non-linear effect on the development of $\mathrm{N}_{2} \mathrm{O}$ emissions, time was included into the analysis as a linear effect. We applied an LME with $\log$-transformed $\mathrm{N}_{2} \mathrm{O}$ emissions and soil mineral $\mathrm{N}$ (representing the response variable). The basic model included the experimental treatments (plant species composition, grazer, type of manure and day) as fixed effects and day and subplot as random effects.

We used LME for time series data, because they account for temporal correlation among observations on the same experimental unit (Piepho et al., 2004). For all LMEmodels, autocorrelation effects were tested before analysis or by modelling heteroscedasticity of residual variance by including variance function (Bliese and Ployhart, 2002). If these measures improved the relative goodness of the model fit (based on the Akaike Information Criterion), the adjustments were included into the model for further analyses (Crawley, 2007), followed by stepwise model simplification. Mean values in the text are given with standard errors. Effects were accepted as statistically significant if $P \leq 0.05$. Analyses were conducted using R version 2.11.1 (R Development Core Team, 2009). 


\subsection{RESULTS}

\subsubsection{N OXIDE EMISSIONS AND SOIL CONTROLS OF THE MAIN EXPERIMENT}

As we found no differences in $\mathrm{N}$ oxide emissions before and after grazing, we averaged the data for $\mathrm{N}_{2} \mathrm{O}$ or $\mathrm{NO}$ emissions. Over the whole experimental period, grazers and plant species composition did not significantly affect mean $\mathrm{N}$ oxide emissions (Table 2.3). Over the grazing season (139 days), cumulative ( \pm standard error) $\mathrm{N}_{2} \mathrm{O}-\mathrm{N}$ emissions $(0.6 \pm$ $\left.0.07 \mathrm{~kg} \mathrm{~N}_{2} \mathrm{O}-\mathrm{N} \mathrm{ha}^{-1}\right)$ exceeded NO-N emissions $\left(0.16 \pm 0.06 \mathrm{~kg} \mathrm{NO}-\mathrm{N} \mathrm{ha}^{-1}\right)$ in all treatments. There were no significant differences among treatments for cumulative $\mathrm{N}_{2} \mathrm{O}$ emissions. Differences in cumulative NO-N emissions were found between treatments GC and GS $(P=$ 0.022), with larger NO-N emissions on GS treatments (Table 2.3). Despite the significance, the differences were very small. Rotation also affected NO emissions: NO emissions were larger during the second grazing rotation compared to the third (with net NO uptake; $P<$ 0.001; Figure 2.2 a). Average $\mathrm{N}_{2} \mathrm{O}$ emissions were small during the first two grazing rotations but increased in the last rotation 2008 and the first $2009(P<0.001$; Figure $2.2 \mathrm{~b})$.

Table 2.3 Mean $\mathrm{N}$ oxide emissions (in $\mu \mathrm{g} \mathrm{N} \mathrm{m}^{-2} \mathrm{~h}^{-1}$ ) and cumulative $\mathrm{N}$ oxide emissions (in $\mathrm{kg} \mathrm{N} \mathrm{ha}^{-1}$ and grazing season of $139 \mathrm{~d}^{-1}$ ) in the treatments at a grassland site in the Solling uplands, Germany.

\begin{tabular}{|c|c|c|c|c|}
\hline Mean* & $\mathrm{DC}$ & DS & $\mathrm{GC}$ & GS \\
\hline $\mathrm{NO}-\mathrm{N}$ & $2.78 \pm 5.1$ & $3.98 \pm 2.9$ & $1.37 \pm 3.0$ & $1.36 \pm 3.17$ \\
\hline $\mathrm{N}_{2} \mathrm{O}-\mathrm{N}$ & $42.9 \pm 9.4$ & $55.3 \pm 26.4$ & $28.2 \pm 11.7$ & $28.4 \pm 11.6$ \\
\hline \multicolumn{5}{|l|}{ Cumulative $^{\S}$} \\
\hline NO-N & $0.31 \pm 0.16$ & $0.19 \pm 0.15$ & $0.03 \pm 0.01 \mathrm{a}$ & $0.13 \pm 0.02 b$ \\
\hline $\mathrm{N}_{2} \mathrm{O}-\mathrm{N}$ & $0.51 \pm 0.13$ & $0.79 \pm 0.13$ & $0.65 \pm 0.16$ & $0.43 \pm 0.05$ \\
\hline $\mathrm{NO}-\mathrm{N}+\mathrm{N}_{2} \mathrm{O}-\mathrm{N}$ & $0.82 \pm 0.10$ & $0.98 \pm 0.30$ & $0.68 \pm 0.31$ & $0.56 \pm 0.15$ \\
\hline
\end{tabular}



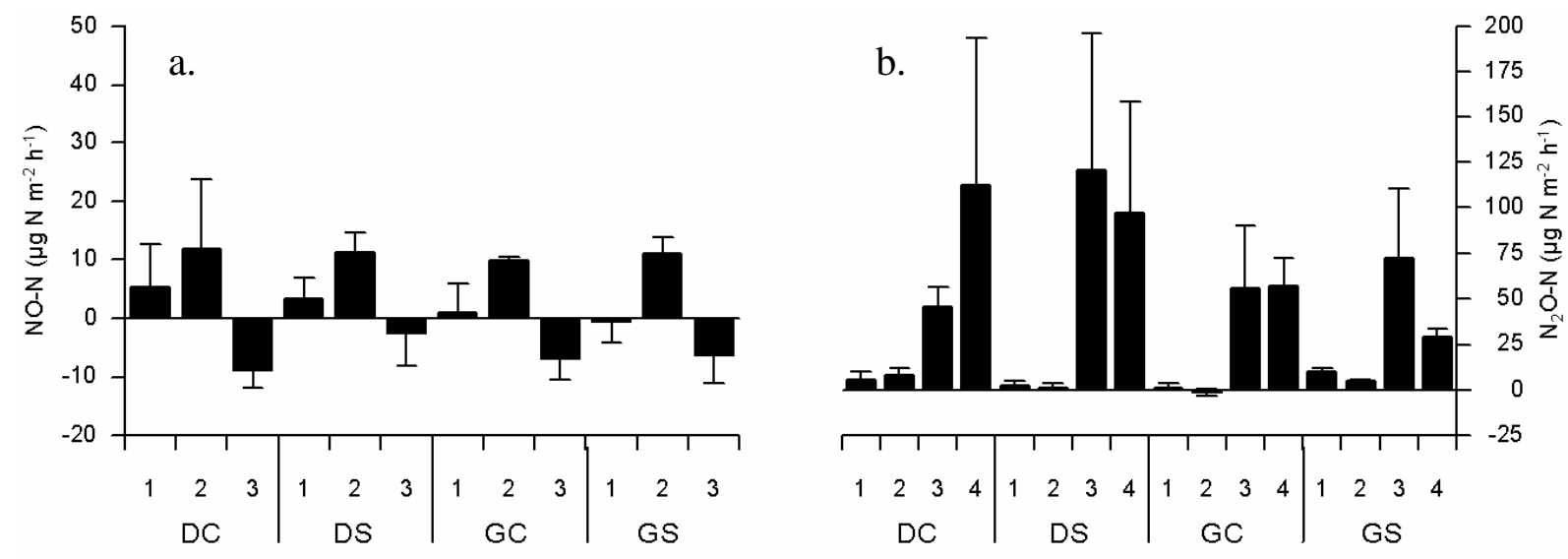

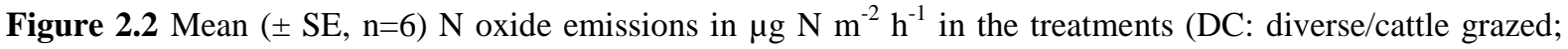
DS: diverse/sheep grazed; GC: grass sward/ cattle grazed; GS: grass sward/sheep grazed) at a grassland site in the Solling uplands, Germany. a. NO-N and b. $\mathrm{N}_{2} \mathrm{O}-\mathrm{N}$ measurements were calculated from measurements before and after grazing and taken for three and for four grazing rotations, respectively. The fourth rotation was the first one 2009 while the others were in 2008. Please note different scales of the y-axes.

$\mathrm{NH}_{4}{ }^{+}$was the dominant form of soil mineral $\mathrm{N}$ in all treatments and did not differ significantly among treatments. Contrary to $\mathrm{N}_{2} \mathrm{O}$ emissions, soil $\mathrm{NH}_{4}{ }^{+}$increased during the first two grazing rotations and decreased by a factor two during the last two grazing rotations $\left(P<0.001\right.$; Figure 2.3 a). Soil mineral $\mathrm{NO}_{3}{ }^{-}$was larger during rotations two and four compared to the others $(P=0.05)$. Plant species composition affected soil mineral $\mathrm{NO}_{3}{ }^{-}(P=$ 0.034), with larger concentration in grass than in diverse swards (Figure $2.3 \mathrm{~b}$ ). The ratio of $\mathrm{N}_{2} \mathrm{O} / \mathrm{NO}$ was linearly correlated to WFPS, air temperature and $\mathrm{NH}_{4}{ }^{+}$concentration $\left(\mathrm{R}^{2}=\right.$ $0.60)$. 

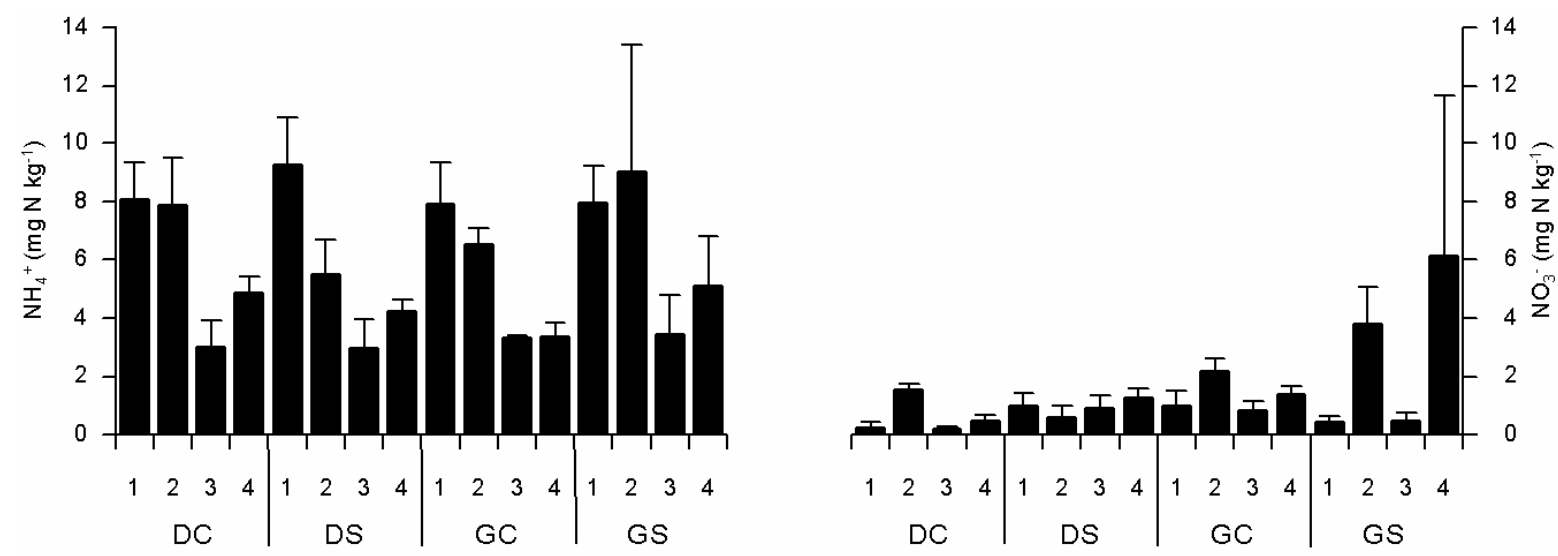

Figure 2.3 Mean $( \pm \mathrm{SE}, \mathrm{n}=6)$ soil mineral $\mathrm{N}$ in $\mathrm{mg} \mathrm{N} \mathrm{kg}^{-1}$ in the treatments (DC: diverse/cattle grazed; DS: diverse/sheep grazed; GC: grass sward/ cattle grazed; GS: grass sward/sheep grazed) at a grassland site in the Solling uplands, Germany. a. $\mathrm{NH}_{4}{ }^{+}$and b. $\mathrm{NO}_{3}{ }^{-}$concentrations were calculated from measurements before and after grazing. Shown are data for the four grazing rotations, three in 2008 and one in 2009.

\subsection{2 $\mathrm{N}_{2} \mathrm{O}$ EMISSIONS AND SOIL CONTROLS OF THE CONTROLLED APPLICATION EXPERIMENT}

In the short-term controlled application experiment, patches treated with cattle urine had a 13-fold $\mathrm{N}_{2} \mathrm{O}-\mathrm{N}$ flux of those with sheep urine, while plots treated with cattle dung showed a 3-fold $\mathrm{N}_{2} \mathrm{O}-\mathrm{N}$ flux of those with sheep dung. The effects of species of grazer $(P=$ 0.002), type of manure $(P=0.002)$ and the interaction between grazer species and manure $(P$ $=0.009$ ) on $\mathrm{N}_{2} \mathrm{O}$ emissions were significant, while plant species composition was not (Figure 2.4). $\mathrm{N}_{2} \mathrm{O}$ emissions of DC-U rose to a peak of $1921 \mu \mathrm{g} \mathrm{N}_{2} \mathrm{O}-\mathrm{N} \mathrm{m}^{-2} \mathrm{~h}^{-1}$ immediately after the application of urine, peaking again at day 6 and 22, but decreased to the level of the control plot $\left(6.3 \mu \mathrm{g} \mathrm{N}_{2} \mathrm{O}-\mathrm{N} \mathrm{m}^{-2} \mathrm{~h}^{-1}\right)$ thereafter. In contrast to that, the $\mathrm{N}_{2} \mathrm{O}$ emissions of $\mathrm{GC}-\mathrm{U}$ increased slowly until day $9\left(527 \mu \mathrm{g} \mathrm{N}_{2} \mathrm{O}-\mathrm{N} \mathrm{m}^{-2} \mathrm{~h}^{-1}\right)$, with largest peaks only appearing at day 18, 24 and 51 after application (Figure 2.4 a). After application of sheep urine, $\mathrm{N}_{2} \mathrm{O}$ emissions of GS-U and DS-U showed distinct developments: $\mathrm{N}_{2} \mathrm{O}$ emissions increased immediately up to $556 \mu \mathrm{g} \mathrm{N}_{2} \mathrm{O}-\mathrm{N} \mathrm{m}^{-2} \mathrm{~h}^{-1}$ (GS-U) and $434 \mu \mathrm{g} \mathrm{N} \mathrm{N}_{2} \mathrm{O}-\mathrm{N} \mathrm{m}^{-2} \mathrm{~h}^{-1}$ (DS-U) upon application but decreased rapidly thereafter (Figure 2.4 b). After dung application, $\mathrm{N}_{2} \mathrm{O}$ emissions of DC-D and GC-D increased steadily over the first days after application, with peaks at day $6\left(145.8 \mu \mathrm{g} \mathrm{N}_{2} \mathrm{O}-\mathrm{N} \mathrm{m}^{-2} \mathrm{~h}^{-1}\right)$ and day $11\left(98 \mu \mathrm{g} \mathrm{N}_{2} \mathrm{O}-\mathrm{N} \mathrm{m}^{-2} \mathrm{~h}^{-1}\right.$; Figure $\left.2.4 \mathrm{c}\right)$. 
$\mathrm{N}_{2} \mathrm{O}$ emissions of DS-D peaked with a slight time-delay at day $30\left(104 \mu \mathrm{g} \mathrm{N}_{2} \mathrm{O}-\mathrm{N} \mathrm{m}^{-2} \mathrm{~h}^{-1}\right)$.

Plots of GS-D showed smallest $\mathrm{N}_{2} \mathrm{O}$ emissions compared to all other treatments. $\mathrm{N}_{2} \mathrm{O}$ emissions over the experimental period peaked here at day $22\left(35.4 \mu \mathrm{g} \mathrm{N} \mathrm{N}_{2} \mathrm{O}-\mathrm{N} \mathrm{m}^{-2} \mathrm{~h}^{-1}\right.$; Figure $2.4 \mathrm{~d})$.
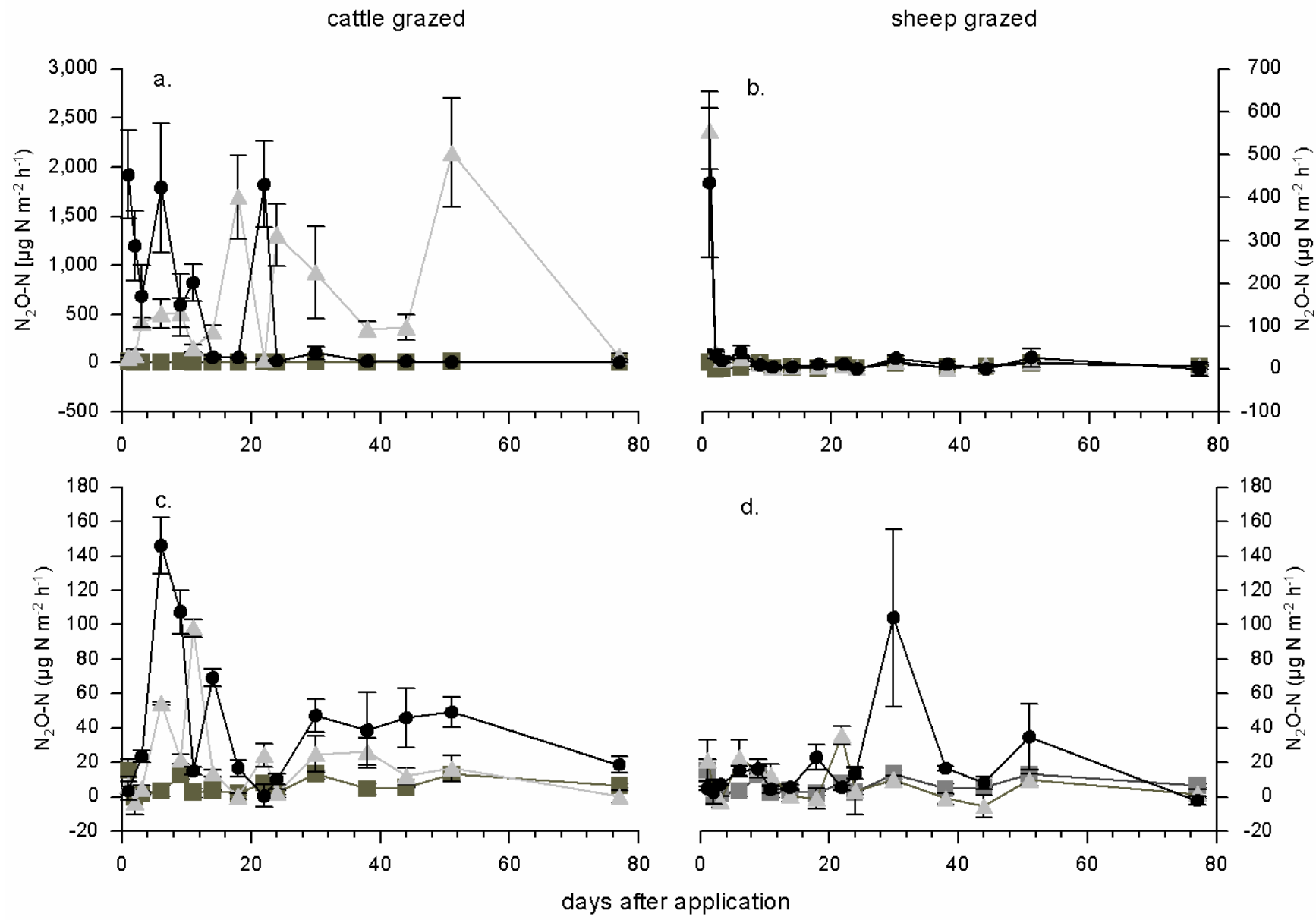

Figure 2.4 $\mathrm{N}_{2} \mathrm{O}-\mathrm{N}$ emissions $\left( \pm \mathrm{SE}, \mathrm{n}=3\right.$ ) in $\mu \mathrm{g} \mathrm{N} \mathrm{m} \mathrm{m}^{-2}$ of the controlled application experiment (period of 77 $\mathrm{d}^{-1}$ ) in diverse $(\bullet)$, grass $(\triangle)$ and control (without excreta addition) (๘) plots at a grassland site in the Solling uplands, Germany. Shown are results for urine-treated plots of a. cattle and b. sheep and dung-treated plots of c. cattle and d. sheep. Please note different scales of the y-axes.

The soil mineral $\mathrm{NH}_{4}{ }^{+}$concentrations of plots treated with cattle and sheep excreta showed similar temporal dynamics, but - regarding urine treatments - at different levels: Cattle urine caused a 2-fold (diverse) to 4-fold (grass sward) increase in the concentration 
compared to plots treated with sheep urine (Figure $2.5 \mathrm{a}-\mathrm{b}$ ). Cattle dung led to similar $\mathrm{NH}_{4}{ }^{+}$ concentrations as sheep dung, with no statistical difference to the controls (Figure $2.5 \mathrm{c}-\mathrm{d}$ ). Grazer species $(P<0.037)$ and type of manure $(P<0.001)$ significantly affected $\mathrm{NH}_{4}^{+}$ concentration.
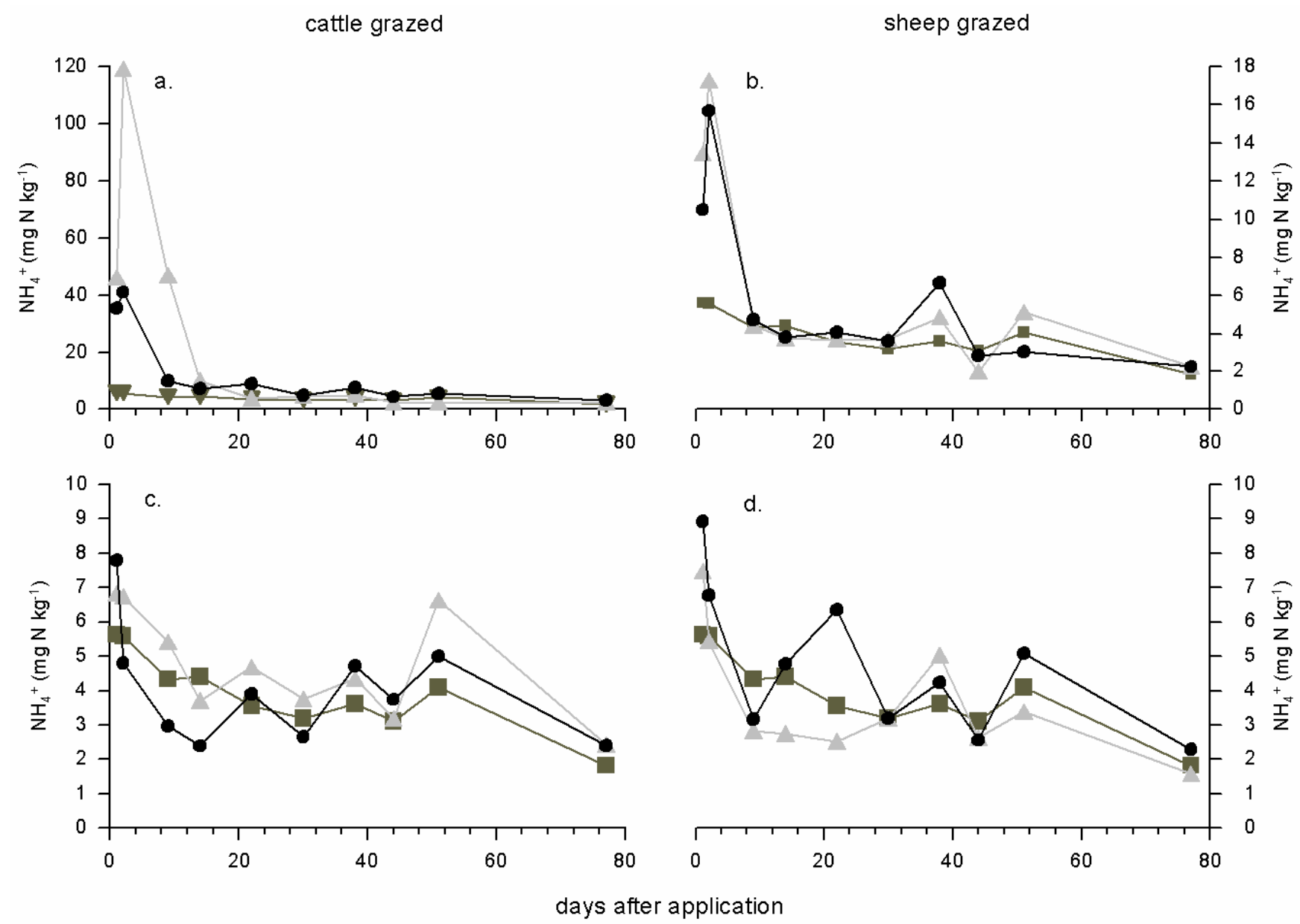

Figure 2.5 Soil mineral $\mathrm{NH}_{4}{ }^{+}$in $\mathrm{mg} \mathrm{N} \mathrm{kg}^{-1}$ of the controlled application experiment (period of $77 \mathrm{~d}^{-1}$ ) in diverse $(\bullet)$, grass sward $(\triangle)$ and control (without excreta addition) ( $\bullet$ ) plots at a grassland site in the Solling uplands, Germany. Shown are results for urine-treated plots of a. cattle and b. sheep and dung-treated plots of c. cattle and d. sheep. Please note different scales of the y-axes.

Soil mineral $\mathrm{NO}_{3}{ }^{-}$concentrations of plots treated with cattle and sheep urine showed comparable dynamics to the $\mathrm{NH}_{4}{ }^{+}$concentrations. Plots treated with cattle urine showed a 3fold (diverse) and 5-fold (grass sward) increase in the concentration compared with plots treated with sheep urine (Figure 2.6 a-b). Plots with cattle dung again had similar 
concentrations as those with sheep dung (for both grass and diverse swards), with no significant differences to the controls (Figure $2.6 \mathrm{c}-\mathrm{d}$ ). Different influences of urine- and dung-treatments and cattle and sheep excreta on soil $\mathrm{NO}_{3}{ }^{-}$concentrations were only detected by the significant influence of day on $\mathrm{NO}_{3}{ }^{-}$concentrations in soils $(P<0.049)$.

cattle grazed
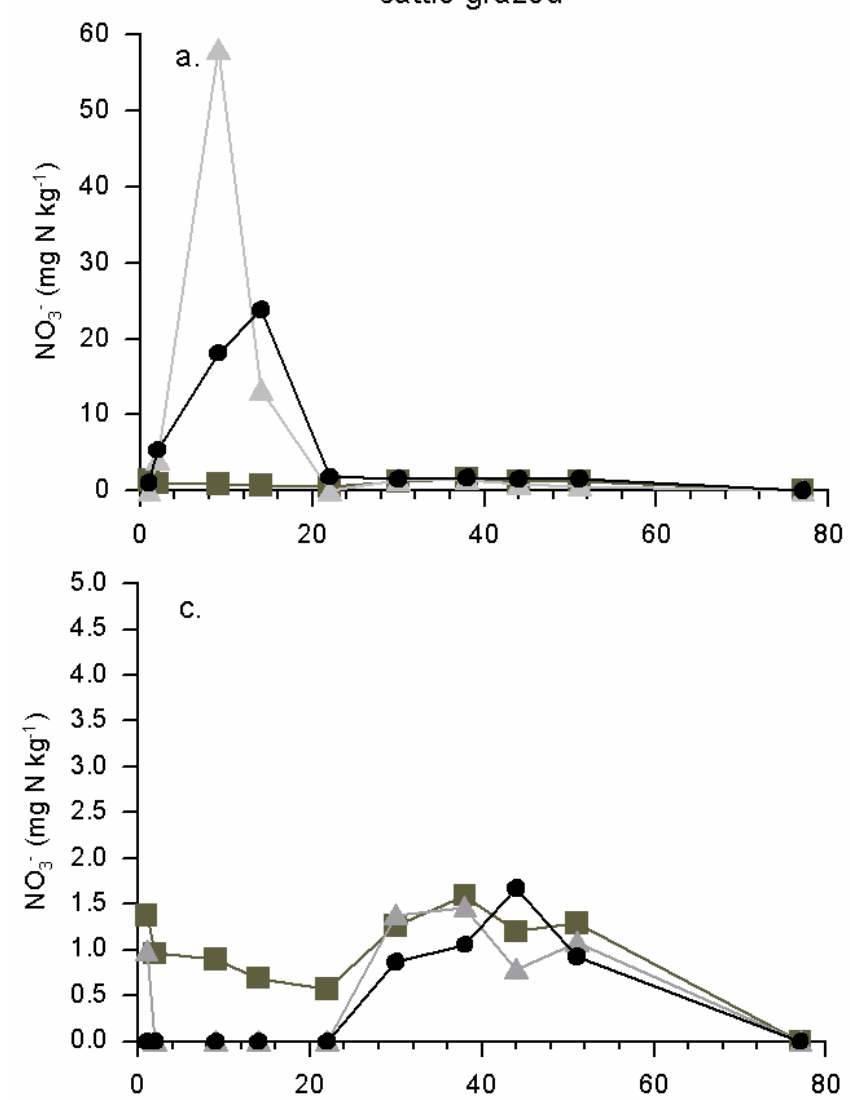

sheep grazed

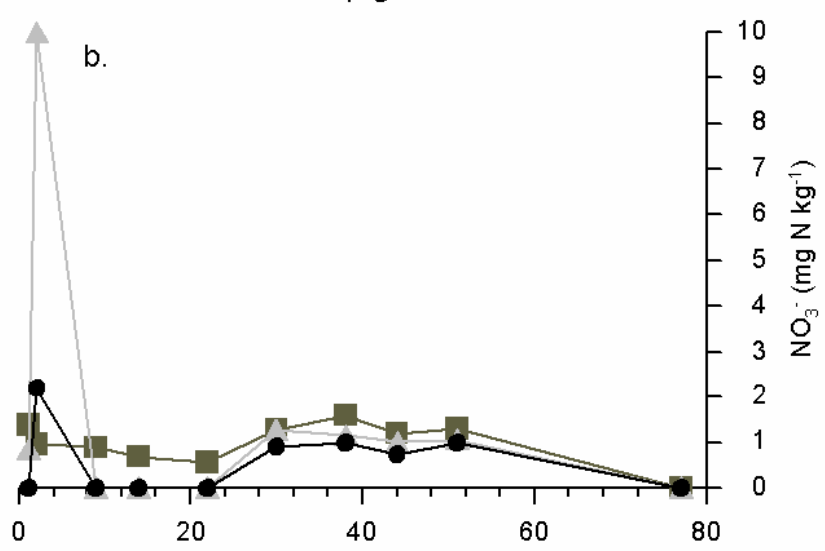

d.

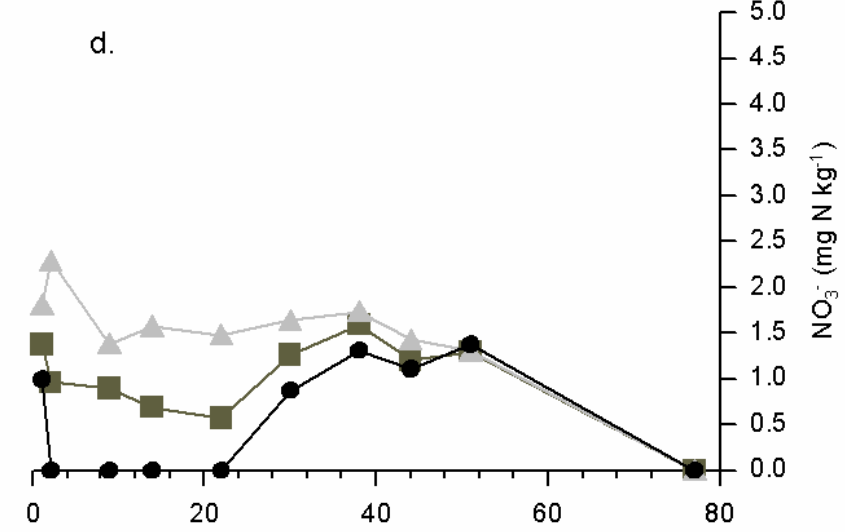

days after application

Figure 2.6 Soil mineral $\mathrm{NO}_{3}{ }^{-}$in $\mathrm{mg} \mathrm{N} \mathrm{kg}^{-1}$ of the controlled application experiment (period of $77 \mathrm{~d}^{-1}$ ) in diverse $(\bullet)$, grass sward $(\rightarrow$ ) and control (without excreta addition) ( $\bullet$ ) plots at a grassland site in the Solling uplands, Germany. Shown are results for urine-treated plots of a. cattle and b. sheep and dung-treated plots of c. cattle and $d$. sheep. Please note different scales of the y-axes. 


\subsubsection{EMISSION FACTORS AND CALCULATION OF EXCRETA $\mathrm{N}$ INPUT AND $\mathrm{N}_{2} \mathrm{O}$-LOSSES ON THE PADDOCK SCALE}

Over the controlled application experiment (77 days), cumulative excreta-derived $\mathrm{N}_{2} \mathrm{O}-\mathrm{N}$ emissions ( \pm standard error) of plots treated with cattle urine $\left(1.03 \pm 0.55 \mathrm{~g} \mathrm{~N}_{2} \mathrm{O}-\mathrm{N} \mathrm{m}^{-}\right.$ ${ }^{2}$ ) exceeded those of plots treated with sheep urine $\left(0.02 \pm 0.002 \mathrm{~g} \mathrm{~N}_{2} \mathrm{O}-\mathrm{N} \mathrm{m}^{-2}\right)$, the same applied for cattle dung $\left(0.04 \pm 0.02 \mathrm{~g} \mathrm{~N}_{2} \mathrm{O}-\mathrm{N} \mathrm{m}^{-2}\right)$ and sheep dung $\left(0.01 \pm 0.01 \mathrm{~g} \mathrm{~N}_{2} \mathrm{O}-\mathrm{N} \mathrm{m}^{-2}\right)$ (Table 2.4). In line with the larger $\mathrm{N}$-input with cattle excreta, the emission factor was smaller for cattle than for sheep urine ( $0.39 \%$ and $0.48 \%$, respectively). Emission factors for dung were also slightly smaller for cattle $(0.05 \%)$ than for sheep $(0.09 \%$; Table 2.4$)$.

Table 2.4 $\mathrm{N}_{2} \mathrm{O}-\mathrm{N}$ emissions and emission factors (EF) in the controlled application experiment and calculated $\mathrm{N}$ input with excreta (amount and area covered) and $\mathrm{N}_{2} \mathrm{O}$ losses in the main experiment at a grassland site in the Solling uplands, Germany. For further explanations, see text.

\begin{tabular}{|c|c|c|c|c|}
\hline $\begin{array}{l}\text { Controlled application } \\
\text { experiment }\end{array}$ & Cattle-urine & Sheep-urine & Cattle-dung & Sheep-dung \\
\hline $\begin{array}{l}\mathrm{N}_{2} \mathrm{O}-\mathrm{N}_{\text {cum }}\left(\mathrm{g} \mathrm{m}^{-2} 77 \mathrm{~d}^{-1}\right)^{*} \\
\mathrm{EF}(\%)^{*}\end{array}$ & $\begin{array}{l}1.03 \pm 0.55 \\
0.39 \pm 0.21 \\
\end{array}$ & $\begin{array}{l}0.02 \pm 0.00 \\
0.48 \pm 0.05\end{array}$ & $\begin{array}{l}0.04 \pm 0.02 \\
0.05 \pm 0.03\end{array}$ & $\begin{array}{l}0.01 \pm 0.01 \\
0.09 \pm 0.11\end{array}$ \\
\hline \multicolumn{5}{|l|}{ Main experiment } \\
\hline $\mathrm{N}$ input $\left(\mathrm{kg} \mathrm{N}\right.$ paddock $\left.\mathrm{d}^{-1} \mathrm{~d}^{-1}\right)$ & 1.81 & 0.28 & 1.06 & 0.07 \\
\hline $\begin{array}{l}\text { Area covered by excreta }\left(\mathrm{m}^{2} \text { paddock }\right. \\
\left.\mathrm{d}^{-1}\right)\end{array}$ & 32.2 & 41.0 & 8.2 & 16.9 \\
\hline $\mathrm{N}_{2} \mathrm{O}-\mathrm{N}_{\text {emitt }}\left(\mathrm{kg}\right.$ paddock $\left.^{-1} \mathrm{~d}^{-1}\right)$ & 0.71 & 0.13 & 0.05 & 0.01 \\
\hline
\end{tabular}

Means $( \pm$ SE, $n=2)$ were calculated from diverse and grass sward. Statistical analyses were not possible.

On a paddock scale (0.5 ha), the calculated $\mathrm{N}$-input with cattle urine $\left(1.81 \mathrm{~g} \mathrm{~N} \mathrm{~m}^{-2}\right)$ exceeded that with sheep urine $\left(0.28 \mathrm{~g} \mathrm{~N} \mathrm{~m}^{-2}\right)$; the same applied for cattle dung $\left(1.06 \mathrm{~g} \mathrm{~N} \mathrm{~m}^{-2}\right)$ and sheep dung (0.07 $\mathrm{g} \mathrm{N} \mathrm{m}^{-2}$ ) (Table 2.4). Based on the emission factors calculated above, the urine-derived $\mathrm{N}_{2} \mathrm{O}-\mathrm{N}$ emissions were larger for cattle- than for sheep-grazed paddocks (0.71 kg N $\mathrm{N}_{2} \mathrm{O}-\mathrm{N} \mathrm{d}^{-1}$ and $0.13 \mathrm{~kg} \mathrm{~N}_{2} \mathrm{O}-\mathrm{N} \mathrm{d}^{-1}$, respectively). Dung-derived $\mathrm{N}_{2} \mathrm{O}-\mathrm{N}$ emissions were also larger in cattle-grazed than sheep-grazed paddocks $\left(0.05 \mathrm{~kg} \mathrm{~N}_{2} \mathrm{O}-\mathrm{N} \mathrm{d}^{-1}\right.$ and $0.01 \mathrm{~kg}$ $\mathrm{N}_{2} \mathrm{O}-\mathrm{N} \mathrm{d}^{-1}$, respectively; Table 2.4). However, the area covered by excreta per paddock was smaller for cattle than for sheep: $32.2 \mathrm{~m}^{2} \mathrm{~d}^{-1}$ were calculated to be covered with cattle urine, $41 \mathrm{~m}^{2} \mathrm{~d}^{-1}$ with sheep urine, and an additional $8.2 \mathrm{~m}^{2} \mathrm{~d}^{-1}$ with cattle dung and $16.9 \mathrm{~m}^{2} \mathrm{~d}^{-1}$ with sheep dung (Table 2.4). 


\subsection{DISCUSSION}

\subsubsection{GRAZER EFFECTS ON N OXIDE EMISSIONS}

The hypothesized larger $\mathrm{N}$ oxide losses on sheep-grazed paddocks compared with those grazed by cattle could only be confirmed for cumulative NO emissions in grass swards in the main experiment (Table 2.3). The observed effects for $\mathrm{N}$ oxide emissions in the other treatments were not consistent. $\mathrm{N}$ oxide losses are linked with the $\mathrm{N}$-supply in the soil, which on pastures depends on the $\mathrm{N}$ applied with excreta. In the controlled application experiment, our finding that $\mathrm{N}_{2} \mathrm{O}$ emissions from cattle excrement-treated plots were larger than from sheep excrement-treated plots was consistent with results of Saggar et al. (2007), who reported plots treated with cattle excreta to have an 8 -fold increase and sheep excreta to result in a 2-fold increase in $\mathrm{N}_{2} \mathrm{O}$ emissions compared to untreated plots. The aim of our experiments was to use maximum $\mathrm{N}_{2} \mathrm{O}$ emissions of the controlled application experiment as an estimate for $\mathrm{N}_{2} \mathrm{O}$ emissions of the main experiment. Beside available $\mathrm{N}$, also soil aeration status and temperature control denitrification and nitrification processes in the soil (Keeney et al., 1979; Linn and Doran, 1984). We checked climate conditions for the duration of the controlled application experiment (77 days) of both years. Mean temperature was $10.7^{\circ} \mathrm{C}$ in 2008 and $11.2^{\circ} \mathrm{C}$ in 2009 , and precipitation rate was $187.0 \mathrm{~mm}$ in 2008 and $178.5 \mathrm{~mm}$ in 2009. Thus, we carefully combined both experiments using the EF derived from the controlled application experiment and the calculated $\mathrm{N}$ input per paddock and day. We calculated expected $\mathrm{N}_{2} \mathrm{O}$ emissions per paddock that were larger for cattle- than for sheepgrazing (Table 2.4). Thus, the amount of $\mathrm{N}$ per excretion cannot explain the missing effect of cattle and sheep on $\mathrm{N}$ oxide emissions in the main experiment.

In the main experiment, measured $\mathrm{N}$ oxide losses were dominated by the occasional measurement of urine and dung hotspots. Our first hypothesis was based on the amount and frequency of urinations and defecations and the number of cattle and sheep per plot, which led to a larger cover with excrements on sheep- than on cattle-grazed plots $(1.16 \%$ of the paddock area per day for sheep grazing, $0.81 \%$ for cattle grazing; Table 2.4) and should thus lead to a larger probability of measuring on hotspots in sheep- than in cattle-grazed pastures. Other studies also concluded that the most apparent reason for differences in $\mathrm{N}_{2} \mathrm{O}$ losses of cattle and sheep excrements are differing quantities of excrements covering the soil and different nutrient concentrations of the excrements (Ma et al., 2006; Williams and Haynes, 
1994). The cover with excreta influences the aeration and the nutrient supply in the soil, and should in turn affect the rate of $\mathrm{N}_{2} \mathrm{O}$ emissions. This should lead to larger emissions from sheep- than from cattle-grazed paddocks, which we did not observe. This could be due to the large spatial and temporal variability in emissions.

We detected larger $\mathrm{N}_{2} \mathrm{O}$ losses of urine patches than in dung patches. Urine patches of both sheep and cattle had larger emissions than dung patches. Due to freeze-thaw events, $\mathrm{N}_{2} \mathrm{O}$ emissions of dung-treated plots measured by Wachendorf et al. (2008) were above those of urine-treated plots, whereas studies of Yamulki et al. (2000) reported larger emissions from urine patches than from dung patches. The typical development of $\mathrm{N}_{2} \mathrm{O}$ emissions after application of urine observed in numerous studies is a rapid increase of $\mathrm{N}_{2} \mathrm{O}$ emissions with a successive decline thereafter, as urinary $\mathrm{N}$ is rapidly hydrolyzed and nitrified in pasture soils (Flessa et al., 1996; Saggar et al., 2007). Our study showed two different developments in $\mathrm{N}_{2} \mathrm{O}$ emissions of plots treated with cattle urine, depending on the plant species composition (Figure 2.4). There are studies yielding similar results for both developments: maximum $\mathrm{N}_{2} \mathrm{O}$ emissions appearing 12-24 h after application were e.g. measured by Sherlock and Goh (1983) and Williams et al. (1999). Studies noting a delayed maximum $\mathrm{N}_{2} \mathrm{O}$ flux after application of urine, showing slow increases of up to 5-14 days after application as observed in our grass plots, were reported by Lovell and Jarvis (1996) or Koops et al. (1997). The observed effect of a delayed increase in $\mathrm{N}_{2} \mathrm{O}$ emissions in the grass swards were inconsistent with results of soil mineral $\mathrm{N}$, which did not show a delayed peak. Soil mineral $\mathrm{NH}_{4}{ }^{+}$und $\mathrm{NO}_{3}{ }^{-}$were 3-fold and 2-fold in the grass swards compared to diverse plots. However, soil mineral $\mathrm{N}$ concentrations in all treatments were the same as in the control plots when the $\mathrm{N}_{2} \mathrm{O}$ peaks appeared at day 18, 24 and 51 after application. The potentially higher nutrient demand of Lolium perenne and Dactylis glomerata compared to herbs or legumes (Mattsson et al., 2009) or a more efficient $\mathrm{N}$ use in diverse swards (Scherer-Lorenzen et al., 2003; Spehn et al., 2002) could not explain these delayed $\mathrm{N}_{2} \mathrm{O}$ emissions in the grass paddocks. However, we observed that some of the plants in the grass sward died off after the cattle urine application, which may have played a role in the delayed $\mathrm{N}_{2} \mathrm{O}$ peaks that we observed. 


\subsubsection{EFFECTS OF SWARD COMPOSITION ON N OXIDE EMISSIONS}

The observed results for $\mathrm{N}$ oxide emissions were not consistent with our hypothesis that more diverse paddocks would have smaller $\mathrm{N}$ oxide emissions than grass swards. Mattsson et al. (2009) argued that high productive grass species such as Lolium perenne and Dactylis glomerata have a higher demand for nutrients from soils than other grass species, herbs or legumes. Legumes may lead to an accumulation of inorganic $\mathrm{N}$ in soils as they symbiotically fix atmospheric $\mathrm{N}_{2}$, but they are generally inefficient in capturing soil extractable N. Furthermore, they may release symbiotically fixed $\mathrm{N}$ into the soil through turnover of root and shoot tissue, which may lead to an accumulation of $\mathrm{NO}_{3}{ }^{-}$as the substrate for denitrification in soils (Hooper and Vitousek, 1997; Niklaus et al., 2006). Legumes can therefore decrease the efficiency of capturing mineral $\mathrm{N}$ that normally results from species diverse grassland swards (Niklaus et al., 2006). However, these studies were not consistent with our observed findings of larger $\mathrm{NO}_{3}{ }^{-}$concentrations in grass than in diverse swards despite similar $\mathrm{N}$ oxide losses. Our findings were supported by the results of $\mathrm{N}$ yield. Regarding plant species composition no significant differences were found for $\mathrm{N}$ yield (Seither et al., 2012). Further research is necessary to better understand influences of plant species composition on $\mathrm{N}$ dynamics in permanent agriculturally managed grassland.

\subsection{CONCLUSIONS}

Combining the data from the two experiments, we conclude that plant species composition was insignificant compared to the effect of grazers on $\mathrm{N}$ oxide emissions. The response of $\mathrm{N}$ oxide emissions on the paddock scale were larger for sheep- compared to cattle-grazing, despite larger emissions per cattle excretion due to the larger amounts of $\mathrm{N}$ per excretion event. We attributed this to a presumably larger paddock surface area covered by sheep than by cattle excreta. 
CHAPTER

3

NITROGEN RESPONSE EFFICIENCY OF A MANAGED AND PHYTODIVERSE TEMPERATE GRASSLAND 


\subsection{ABSTRACT}

Aims Our goal was to assess how management and sward functional diversity affect nitrogen response efficiency (NRE), the ratio of plant biomass production to supply of available nitrogen $(\mathrm{N})$ in temperate grassland.

Methods A three-factorial design was employed: three sward compositions, two mowing frequencies, and two fertilization treatments.

Results NRE was largely influenced by fertilization followed by mowing frequency and sward composition. NRE was larger in unfertilized than fertilized plots, in plots cut thrice than plots cut once per year, and in control swards than in monocot- or dicot enhanced swards. Fertilization decreased NRE through decreases in both $\mathrm{N}$ uptake efficiency (plant $\mathrm{N}$ uptake per supply of available $\mathrm{N}$ ) and $\mathrm{N}$ use efficiency (NUE, biomass produced per plant $\mathrm{N}$ uptake) whereas mowing frequency and sward composition affected NRE through N uptake efficiency rather than NUE. The largest NRE in the control sward with $70 \%$ monocots and $30 \%$ dicots attests that these proportions of functional groups were best adapted in this grassland ecosystem.

Conclusions Optimum NRE may not be a target of most farmers, but it is an appropriate tool to evaluate the consequences of grassland management practices, which farmers may employ to maximize profit, on environmental quality.

Keywords: $\mathrm{N}$ uptake efficiency, $\mathrm{N}$ use efficiency, net $\mathrm{N}$ mineralization rates, functional diversity

\subsection{INTRODUCTION}

Nutrient response efficiency, the amount of biomass produced per unit of plantavailable nutrients (Pastor and Bridgham, 1999), is a measure of ecosystem functioning that integrates productivity and the retention of nutrients (Hiremath and Ewel, 2001). In terrestrial ecosystems where nitrogen $(\mathrm{N})$ is limiting net primary productivity (Vitousek and Howarth, 
1991), the efficient use of available $\mathrm{N}$ may give communities a competitive advantage over communities that are less efficient in using $\mathrm{N}$ (Bridgham et al., 1995). There is no common agreement about the definitions of nitrogen response efficiency (NRE) and nitrogen use efficiency (NUE) in literature (Aerts, 1990; Vitousek, 1982; Xu et al., 2012). In our study, $\mathrm{NRE}$ is calculated as the product of $\mathrm{N}$ uptake efficiency (defined as plant $\mathrm{N}$ concentration $\mathrm{x}$ plant biomass $\div$ soil available $\mathrm{N}$ ) and NUE (defined as plant biomass $\div$ plant $\mathrm{N}$ concentration $\mathrm{x}$ plant biomass), two indices that are commonly used to evaluate the role of $\mathrm{N}$ in ecosystem productivity (Pastor and Bridgham, 1999). However, both indices give an incomplete picture of how $\mathrm{N}$ availability affects biomass production. A large NUE does not necessarily reflect a large productivity because NUE can increase or decrease if the plant $\mathrm{N}$ concentration changes even if plant biomass stays the same. NUE is also often not well correlated with soil $\mathrm{N}$ availability (Iversen et al., 2010). Similarly, N uptake efficiency does not directly indicate productivity as it is influenced by changes in plant $\mathrm{N}$ concentration. In contrast, NRE is an index that reflects the ability of plants to acquire $\mathrm{N}$ from the soil and to use it for biomass production once it is taken up (Bridgham et al., 1995), and thus it is a better index if biomass production is the main goal (as is the case in most temperate grasslands). Since a large NRE indicates a large biomass production per unit of soil available $\mathrm{N}$ and thus a large $\mathrm{N}$ retention in plants, it is inversely correlated with $\mathrm{N}$ lost, e.g. through nitrate $\left(\mathrm{NO}_{3}{ }^{-}\right)$leaching and gaseous $\mathrm{N}$ emissions. A large NRE may thus contribute to the reduction of reactive $\mathrm{N}$ in the soil, which affects water and air pollution as well as the emission of greenhouse gases (Dobermann, 2005).

Pastor and Bridgham (1999) developed a general model of NRE showing maximum efficiency at intermediate levels of $\mathrm{N}$ availability. In their model, productivity $\left(\mathrm{P}_{\mathrm{N} \text { supply }}\right)$ at a given level of available $\mathrm{N}$ (i.e. $\mathrm{N}$ supply in the environment) is defined as:

$\mathrm{P}_{\mathrm{N} \text { supply }}=\mathrm{N}$ supply $*(\mathrm{P} \div \mathrm{N}$ supply $)+0$

In this model, NRE is the slope of a line from the origin to a given point of the function that describes the relationship between productivity and $\mathrm{N}$ supply (Pastor and Bridgham, 1999). This implies that NRE changes with N supply and depends on the shape of the function in Eq. 2. If the relationship between productivity and $\mathrm{N}$ supply is linear, NRE is constant across a gradient of $\mathrm{N}$ supply. However, a linear relationship over a wide range of $\mathrm{N}$ supply is unlikely given the observation that no further increase in productivity occurs at high levels of $\mathrm{N}$ availability (Pastor and Bridgham, 1999). Studies that investigated the 
relationships between NRE and soil $\mathrm{N}$ availability found increases in NRE as soil $\mathrm{N}$ availability declined in an experimental plantation of tropical trees (Hiremath and Ewel, 2001; Yuan et al., 2006). Bridgham et al. (1995) gave a mathematical proof that nutrient response efficiency has to be unimodal across broad ranges of nutrient supply. However, the unimodal efficiency has not been observed for $\mathrm{N}$ so far and is debatable (Yuan et al., 2006). A monotonic increase of NRE with decreasing soil $\mathrm{N}$ availability was observed by Yuan et al. (2006) for Mongolian grassland.

NRE can be influenced by management practices and plant diversity through their effects on $\mathrm{N}$ availability, uptake efficiency and NUE. Management practices commonly employed in grasslands are fertilization and mowing. Fertilization directly influences $\mathrm{N}$ availability. Furthermore, mowing removes available $\mathrm{N}$ from the ecosystem through the mown biomass. In systems with large nutrient availability, mowing may mitigate the negative effects of nutrient enrichment on plant diversity by removing excess nutrients (Ellenberg and Leuschner, 2010; Pykälä, 2000). Mowing can also lead to a denser root system in the top soil by increasing the root-to-shoot-ratio and thus causing a more effective plant $\mathrm{N}$ uptake (Kammann et al., 1998; Mooney and Winner, 1991). In contrast, an increase in allocation of resources to the shoots (Guitian and Bardgett, 2000) as well as a decrease in root biomass following defoliation have been reported by other studies (Dawson et al. 2000; Holland and Detling, 1990). Mikola et al. (2009) also reported that even for grazed grasslands defoliation is the most important mechanism explaining grazing effects on plant attributes while excreta return play only a minor role. To date, there are no published studies on how $\mathrm{N}$ fertilization, mowing frequency and their interactions affects NRE of temperate grasslands, and thus the present study is the first to report such pattern.

Apart from direct effects, management practices may also affect NRE through a change in species composition of the sward. In the past six decades, European grasslands have undergone many changes in management (e.g. increased fertilizer input and mowing frequency, or abandonment from agricultural use) that had profound consequences for biodiversity (Isselstein et al., 2005). The impact of plant diversity on nutrient uptake, productivity and NRE has been subject of several studies. Hiremath and Ewel (2001) reported an increase in $\mathrm{N}$ uptake efficiency with increase in life-form diversity for a tropical tree plantation. Several studies showed that more diverse grasslands were more productive (e.g. Hector et al., 1999; Tilman et al., 1996; Weigelt et al., 2009) with an increased nutrient 
retention from more diverse grassland ecosystems (Tilman et al., 1996). Furthermore, van Ruijven and Berendse (2005) observed an increase in productivity and NUE with increasing species richness. These studies, however, were conducted in experimentally-established plots that were weeded intensively, or in microcosms, making them difficult to compare with results from permanent grasslands where no clear effect of biodiversity on productivity has yet been demonstrated (Wrage et al., 2011). This may be due to the larger species richness in permanent grassland compared to many studies where diversity effects were largest at species richness levels smaller than five species (Wrage et al., 2011). Although Flombaum and Sala (2008) reported a larger effect of plant biodiversity on productivity in a natural grassland ecosystem compared to artificial ecosystems, their study only included a biodiversity gradient of one to six species, which is still considerably lower than managed, temperate grasslands with 10 to 60 plant species (Wrage et al., 2011). So far no studies on the impact of management practices, sward composition and their interactions on NRE in agriculturallymanaged, permanent grassland have been published. As the efficiency with which grasslands use available $\mathrm{N}$ for biomass production is the key link between management and biogeochemical $\mathrm{N}$ cycling, our goal was to evaluate how NRE changes as a function of different management practices and sward compositions in an agriculturally-managed, permanent grassland site. We measured NRE of a grassland site that was managed according to local practices in the Solling Mountains (Lower Saxony, Germany). Here, we only considered the harvestable, aboveground biomass because our study focuses on agricultural management practices. Plant functional group diversity was manipulated by herbicide treatments, resulting in dicot-enhanced swards with nearly equal proportions of dicots and monocots, control swards with $\sim 70 \%$ monocots and $\sim 30 \%$ dicots, and monocot-enhanced swards with $\sim 90 \%$ monocots and $\sim 10 \%$ dicots. Species richness was significantly smaller in the monocot-enhanced swards compared to the control swards (Petersen et al., 2012). N supply (used as the measure of $\mathrm{N}$ availability in the environment) was defined as the sum of soil net $\mathrm{N}$ mineralization rates during the growing season, $\mathrm{N}$ deposition from bulk precipitation, and fertilizer addition rates. We tested the following hypotheses: 1) unfertilized plots have larger NRE than fertilized plots, 2) plots with high mowing frequency have larger NRE than plots with low mowing frequency, and 3) NRE increases with increasing number of species (i.e. monocot-enhanced swards (12-13 species) < dicot-enhanced (17 species) and control swards (16-18 species)). 


\subsection{MATERIALS AND METHODS}

\subsubsection{STUDY SITE}

This interdisciplinary research project, grassland management experiment or GRASSMAN, was conducted at the experimental farm of the University of Goettingen on a moderately species-rich grassland in the Solling Mountains in Lower Saxony, Germany $\left(51^{\circ} 44^{\prime} 53^{\prime \prime} \mathrm{N}, 9^{\circ} 32^{\prime} 42^{\prime \prime E}, 490 \mathrm{~m}\right.$ above sea level). This permanent grassland site has traditionally been used as a pasture for hay making or for grazing (Geological Map of Prussia 1910 (based on the topographic inventory of 1896); topographic maps of Sievershausen and Neuhaus/Solling 1924, 1956 and 1974; Braunschweigische Landesaufnahme 18th century). In the last five decades, the study site was managed with moderate fertilization ( $80 \mathrm{~kg} \mathrm{~N} \mathrm{ha-1}$ yr-1), liming, overseeding with high value forage species and cattle grazing (farm records of Relliehausen since 1966). Fertilization stopped two years before our experiment started. Vegetation consists of a montane, semi-moist Lolio-Cynosuretum. Mean annual precipitation is $1028 \mathrm{~mm}$ and mean annual temperature is $6.9^{\circ} \mathrm{C}$ (Deutscher Wetterdienst, $1961-1990$, station Holzminden-Silberborn, $440 \mathrm{~m}$ above sea level). During the study period, mean annual temperature and annual precipitation were $8.4^{\circ} \mathrm{C}$ and $1001 \mathrm{~mm}$ in 2009 and $8.0^{\circ} \mathrm{C}$ and $1110 \mathrm{~mm}$ in 2010. The dominating soil type is a Haplic Cambisol, developed on sediments of loess on the Middle Buntsandstein formation with a loamy silt texture.

\subsubsection{EXPERIMENTAL SET UP}

The study had a three-factorial design: three sward compositions, two mowing frequencies and two fertilization treatments. In June 2008, we established three sward compositions by applying a herbicide mixture against dicotyledons (Starane ${ }^{\circledR}$ (active ingredients: Fluoroxypyr and Triclopyr) and Duplosan KV (active ingredients: Mecoprop$P ®))$ resulting in a sward with reduced proportions of herbs and legumes, a herbicide mixture against monocotyledons (Select 240 EC® by Stähler (active ingredients: Clethodim)) resulting in a sward with reduced proportions of grasses, and an untreated control sward. Hereafter, we refer to these sward compositions as monocot-enhanced (12-13 species; 9193\% grasses, 7-9\% herbs and 0\% legumes) and dicot-enhanced (17 species; 40-47\% grasses, 
$49-53 \%$ herbs and 4-9\% legumes) relative to the control sward (16-18 species; $68-76 \%$ grasses, 21-31\% herbs and 1-4\% legumes) (Petersen et al., 2012). In 2008, all experimental plots were mown, and fertilized plots received $50 \mathrm{~kg} \mathrm{~N}$ ha $^{-1}$. The experiment started in spring 2009 with two mowing frequencies (once per year in July and thrice per year in May, July and September) as well as two fertilization treatments $\left(180-30-100 \mathrm{~kg} \mathrm{NPK} \mathrm{ha}^{-1} \mathrm{yr}^{-1}\right.$ and no fertilization). The $\mathrm{N}$ fertilizer (calcium ammonium nitrate $\mathrm{N} 27$ ) was split into two equal applications per year (April and May 2009 and April and June 2010) while the combined P and K fertilizer was applied once a year (June 2009 and 2010). The experimental treatments were set up with 6 replicates in a full factorial design (72 plots; $15 \mathrm{~m} \mathrm{x} 15 \mathrm{~m}$ each) arranged in a Latin rectangle.

\subsubsection{SOIL CHARACTERISTICS}

Soil characteristics (Table 3.1) were determined in spring 2008 (chemical and texture analyses) and summer 2009 (bulk density). At nine sampling points per plot, mineral soils (0.01-0.1 m depth) were sampled, pooled, oven-dried $\left(40^{\circ} \mathrm{C}\right)$ for a week and sieved $(2 \mathrm{~mm})$. Particle size distribution was determined by wet sieving $(>20<630 \mu \mathrm{m})$ and pipette methods $(\leq 20 \mu \mathrm{m})$ after pre-treatment with $30 \% \mathrm{H}_{2} \mathrm{O}_{2}$ and $4 \%$ Na-dithionite-citrate solution to remove organic matter and iron oxides (Schlichting et al., 1995). Soil bulk density was determined by soil core method (Blake and Hartge, 1986). Cation exchange capacity (CEC) was determined using the method of 0.1 mol $\mathrm{BaCl}_{2}$ percolation (König and Fortmann, 1996) and measuring cations in percolates using Inductively Coupled Plasma - Optical Emission Spectrometry (Optima 3000 XL, Perkin Elmer, Rodgau, Germany). Base saturation was determined as the percentage exchangeable base cations of the CEC. Soil $\mathrm{pH}$ was measured from soil:water suspension (ratio of 1:2). Total $\mathrm{C}$ and $\mathrm{N}$ concentrations were determined from ground soils using a CN elemental analyzer (Elementar Vario EL III, Hanau, Germany). 
Table 3.1 Soil characteristics in the Ah horizon (0.01-0.1 m) of a Haplic Cambisol of a grassland site in the Solling Mountains, Germany.

\begin{tabular}{|c|c|c|c|}
\hline Physical and chemical ${ }^{*}$ properties & Mean & SE & $\mathrm{n}$ \\
\hline Sand (\%) & 21.62 & 1.2 & 18 \\
\hline Silt $(\%)$ & 66.53 & 1.3 & 18 \\
\hline Clay $(\%)$ & 11.85 & 0.8 & 18 \\
\hline Bulk density $\left(\mathrm{g} \mathrm{cm}^{-3}\right)$ & 0.79 & 0.01 & 72 \\
\hline Cation exchange capacity $\left(\mathrm{mmol}_{\mathrm{c}} \mathrm{kg}^{-1}\right)$ & 169.00 & 5.2 & 72 \\
\hline Base saturation (\%) & 37.18 & 1.4 & 72 \\
\hline $\mathrm{pH}\left(1: 2 \mathrm{H}_{2} \mathrm{O}\right)$ & 5.34 & 0.03 & 72 \\
\hline Carbon : Nitrogen ratio & 12.60 & 0.04 & 72 \\
\hline
\end{tabular}

\subsubsection{BIOMASS YIELD AND PLANT N UPTAKE}

Data of aboveground biomass was reported by From et al. (2011) (see Appendix Table A.1). The grassland was mown in mid-July for plots with one-cut $\mathrm{yr}^{-1}$ and in mid-May, mid-July and end of September of each year for plots with three-cuts $\mathrm{yr}^{-1}$. A Haldrup (C) forage combine harvester was used with a cutting height of $7 \mathrm{~cm}$. Dry mass of the biomass was determined by oven-drying at $60^{\circ} \mathrm{C}$ to constant mass. Oven-dried plant samples from the second cut (mid-July) were ground and analyzed for total $\mathrm{N}$ concentration using a CNS elemental analyser (Elementar Vario El, Hanau, Germany). Plant $\mathrm{N}$ uptake ( $\left.\mathrm{kg} \mathrm{N} \mathrm{ha}^{-1} \mathrm{yr}^{-1}\right)$ was calculated as: $\mathrm{N}$ concentration $\left(\mathrm{kg} \mathrm{N} \mathrm{kg}^{-1}\right) *$ biomass yield $\left(\mathrm{kg} \mathrm{ha}^{-1} \mathrm{yr}^{-1}\right)$ (Hiremath and Ewel, 2001). 


\subsubsection{SOIL NET N MINERALIZATION RATES, N SUPPLY, AND N RESPONSE EFFICIENCY}

Net $\mathrm{N}$ mineralization rates were measured five times (April, May, June, August and October) in 2009 and six times (April, May, June, July, August and September) in 2010 using the buried bag method. In each plot, two intact soil cores were taken from the Ah mineral soil (0.01-0.10 m). The soil from one core was transferred into a plastic bag, crumbled, mixed well, and extracted directly in the field by taking a subsample and adding this to a prepared bottle containing $150 \mathrm{ml} 0.5 \mathrm{~mol} \mathrm{~L}^{-1} \mathrm{~K}_{2} \mathrm{SO}_{4}$ (average dry soil mass to solution ratio was 1:3) ( $T_{0}$ cores). The other soil core was put in a plastic bag that was loosely tied to permit aeration but prevent rain from entering, inserted back into the hole to incubate in-situ for ten days, and extracted in a similar manner ( $T_{1}$ cores). The soil- $\mathrm{K}_{2} \mathrm{SO}_{4}$ bottles were brought to the laboratory within 6 hours, where extraction continued by shaking the bottles for one hour and filtering through $\mathrm{K}_{2} \mathrm{SO}_{4}$-prewashed filter papers ( $4 \mu \mathrm{m}$ nominal pore size). Extracts were immediately frozen until analysis. Ammonium $\left(\mathrm{NH}_{4}{ }^{+}\right)$and $\mathrm{NO}_{3}^{-}$were measured using continuous flow injection colorimetry (Skalar, Cenco Instruments, Breda, The Netherlands), in which $\mathrm{NH}_{4}{ }^{+}$was determined using the Berthelot reaction method (Skalar Method 155-000) and $\mathrm{NO}_{3}{ }^{-}$was measured using the copper-cadmium reduction method (Skalar Method 461000). Gravimetric moisture content was determined for each soil sample by oven-drying at $105^{\circ} \mathrm{C}$ for 24 hours. Net $\mathrm{N}$ mineralization was calculated as the difference between $T_{1}$ - and $T_{0}$-mineral $\mathrm{N}\left(\mathrm{NH}_{4}{ }^{+}+\mathrm{NO}_{3}{ }^{-}\right)$. This assay of net production of mineral $\mathrm{N}$ in soil under in-situ conditions in the absence of plants provides an index of plant-available N (Hart et al., 1994).

$\mathrm{N}$ supply of each plot is defined as the sum of cumulative net $\mathrm{N}$ mineralization rates of the soil, $\mathrm{N}$ fertilization and $\mathrm{N}$ deposition rates. Cumulative net $\mathrm{N}$ mineralization rates during a growing season (i.e. April - September) were calculated by applying the trapezoid rule on time intervals between measured rates. For $\mathrm{N}$ deposition, we used a value of $12.6 \mathrm{~kg}$ $\mathrm{N} \mathrm{ha}^{-1} \mathrm{yr}^{-1}$ from bulk precipitation measured within the scope of the EU-level II monitoring program (Keuffel-Türk et al., in press). NRE was calculated for each plot as:

$\operatorname{NRE}\left(\mathrm{kg}\right.$ biomass $\left.\mathrm{kg} \mathrm{N}^{-1}\right)=$

(plant $\mathrm{N}$ uptake $\div \mathrm{N}$ supply) $*$ (biomass yield $\div$ plant $\mathrm{N}$ uptake)

The ratio of plant $\mathrm{N}$ uptake to $\mathrm{N}$ supply is referred to as $\mathrm{N}$ uptake efficiency whereas the ratio of biomass yield to plant N uptake is the NUE (Hiremath and Ewel, 2001; Pastor and Bridgham, 1999). 


\subsubsection{STATISTICAL ANALYSES}

Effects of treatments on time series data (net $\mathrm{N}$ mineralization rates) were conducted using linear mixed effects models (LME) with treatments and their interactions as fixed effects and spatial replication and time as random effects. The LME model includes either 1) a variance function that allows different variances of the response variable for the fixed effects, 2) a first-order temporal autoregressive process that assumes the correlation between measurements decreases with increasing time difference, or 3) both if this improves the relative goodness of model fit based on the Akaike Information Criterion (Crawley, 2007). Treatment effects on biomass yield, plant $\mathrm{N}$ uptake, $\mathrm{N}$ supply, NRE, NUE and uptake efficiency were assessed using three-way analysis of variance (ANOVA) with Tukey's HSD test. In all tests, if residual plots revealed non-normal distribution or non-homogeneity of variance, we used either logarithmic or square root transformation (after adding a constant value if the dataset included negative values) and analyses were repeated. Effects were accepted as statistically significant if $P \leq 0.05$. All statistical analyses were conducted using the R version 2.11.1 (R Development Core Team, 2009).

\subsection{RESULTS}

\subsubsection{BIOMASS YIELD AND PLANT N UPTAKE}

In 2009, biomass yield ranged from 4048 to $14647 \mathrm{~kg} \mathrm{ha}^{-1} \mathrm{yr}^{-1}$ with an overall mean of 7758 ( $\pm 309 \mathrm{SE}) \mathrm{kg} \mathrm{ha}^{-1} \mathrm{yr}^{-1}$. Fertilization as well as increasing mowing frequency increased biomass yield, and plots cut thrice per year responded stronger to fertilization than plots cut once per year (Table A.1). In 2010, biomass yield decreased to values between 1960 and $12983 \mathrm{~kg} \mathrm{ha}^{-1} \mathrm{yr}^{-1}$ with a mean of $5612 \mathrm{~kg} \mathrm{ha}^{-1} \mathrm{yr}^{-1}$. Compared to 2009, the interaction between mowing frequency and fertilization was even more pronounced (i.e. larger explained variance). Fertilization only resulted in larger yields in plots with three cuts per year whereas no fertilization effect could be detected in plots with one cut per year (Table A.1). Apart from fertilization and mowing frequency, sward composition also influenced biomass yield in 2010 but it explained only a small fraction of the variation. Control swards had larger yields compared to monocot-enhanced swards and both did not differ from dicot-enhanced swards. 
Plant $\mathrm{N}$ uptake in 2009 ranged from 51.37 to $340.84 \mathrm{~kg} \mathrm{~N} \mathrm{ha}^{-1} \mathrm{yr}^{-1}$ with a mean of 147.38 ( \pm 17.37 SE) $\mathrm{kg} \mathrm{ha}^{-1} \mathrm{yr}^{-1}$. Fertilization significantly enhanced plant $\mathrm{N}$ uptake and explained by far the largest part of its variance. This was followed by mowing frequency with larger plant $\mathrm{N}$ uptake in plots cut thrice than once a year (Table 3.2). However, an interaction between fertilization and mowing frequency showed that mowing frequency only affected plant $\mathrm{N}$ uptake on the fertilized plots. In 2010, plant $\mathrm{N}$ uptake ranged from 27.82 to $273.39 \mathrm{~kg}$ $\mathrm{N} \mathrm{kg}^{-1} \mathrm{yr}^{-1}$ with a mean of $98.87( \pm 11.65 \mathrm{SE}) \mathrm{kg} \mathrm{ha}^{-1} \mathrm{yr}^{-1}$. As before, fertilization, mowing frequency and their interaction showed significant effects with larger plant $\mathrm{N}$ uptake in fertilized than unfertilized plots, and in plots cut thrice than once per year. The effect of fertilization was less pronounced and that of mowing frequency was larger compared to 2009. Mowing frequency significantly affected plant $\mathrm{N}$ uptake on both fertilized and unfertilized plots, but fertilized plots were more strongly influenced than unfertilized plots (Table 3.2). 
Table 3.2 Plant N uptake of a grassland under different management practices in the Solling Mountains, Germany.

\begin{tabular}{|c|c|c|c|c|c|c|c|c|c|c|}
\hline \multirow[b]{2}{*}{ Main factors } & \multirow[b]{2}{*}{ Treatments } & \multirow[b]{2}{*}{$\mathrm{n}$} & \multicolumn{4}{|c|}{2009} & \multicolumn{4}{|c|}{2010} \\
\hline & & & $\begin{array}{l}\text { Plant N uptake } \\
\left(\mathrm{kg} \mathrm{N} \mathrm{ha}^{-1} \mathrm{yr}^{-1}\right)\end{array}$ & SE & $P$ & $\begin{array}{l}\text { Variance } \\
\text { explained } \\
(\%)\end{array}$ & $\begin{array}{l}\text { Plant N uptake } \\
\left(\mathrm{kg} \mathrm{N} \mathrm{ha}^{-1} \mathrm{yr}^{-1}\right)\end{array}$ & $\mathrm{SE}$ & $P$ & $\begin{array}{l}\text { Variance } \\
\text { explained } \\
(\%)\end{array}$ \\
\hline \multirow[t]{4}{*}{ Sward compo } & & & & & 0.540 & 0.21 & & & 0.072 & 1.10 \\
\hline & control & 24 & $147.37 \mathrm{a}$ & 16.24 & & & $106.64 \mathrm{a}$ & 13.03 & & \\
\hline & monocot-enhanced & 24 & $143.20 \mathrm{a}$ & 15.69 & & & $94.23 \mathrm{a}$ & 12.26 & & \\
\hline & dicot-enhanced & 24 & $151.56 \mathrm{a}$ & 14.99 & & & $95.73 \mathrm{a}$ & 10.49 & & \\
\hline \multirow[t]{3}{*}{ Mowing frequ } & & & & & $<0.000$ & 13.17 & & & $<0.000$ & 20.78 \\
\hline & once per year & 36 & $120.11 \mathrm{~b}$ & 8.35 & & & $71.27 \mathrm{~b}$ & 4.06 & & \\
\hline & thrice per year & 36 & $174.65 \mathrm{a}$ & 14.50 & & & $126.46 \mathrm{a}$ & 11.41 & & \\
\hline \multirow[t]{3}{*}{ Fertilization } & & & & & $<0.000$ & 66.88 & & & $<0.000$ & 56.66 \\
\hline & no & 36 & $85.93 \mathrm{~b}$ & 4.15 & & & $59.73 \mathrm{~b}$ & 2.66 & & \\
\hline & NPK & 36 & 208.83 a & 9.47 & & & $138.00 \mathrm{a}$ & 9.78 & & \\
\hline \multicolumn{2}{|c|}{ Fertilization $\mathrm{x}$ mowing frequency } & & & & $<0.000$ & 5.40 & & & $<0.000$ & 7.93 \\
\hline no & once per year & 18 & $76.12 \mathrm{c}$ & 3.33 & & & $54.39 \mathrm{~d}$ & 3.26 & & \\
\hline NPK & once per year & 18 & $164.11 \mathrm{~b}$ & 6.91 & & & $88.15 \mathrm{~b}$ & 4.87 & & \\
\hline no & thrice per year & 18 & $95.75 \mathrm{c}$ & 6.90 & & & $65.06 \mathrm{c}$ & 3.88 & & \\
\hline NPK & thrice per year & 18 & $253.55 \mathrm{a}$ & 9.28 & & & $187.85 \mathrm{a}$ & 8.81 & & \\
\hline
\end{tabular}

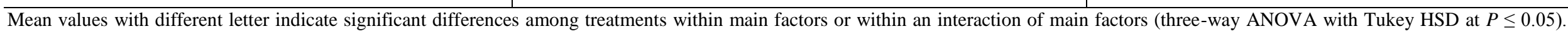
Treatment interactions that were not significant are not reported. 


\subsubsection{SOIL NET N MINERALIZATION RATES AND N SUPPLY}

Net $\mathrm{N}$ mineralization rates showed a clear seasonal pattern with large rates in summer and small rates in spring and fall. In 2009, net $\mathrm{N}$ mineralization rates varied between -13 and $135 \mathrm{~kg} \mathrm{~N} \mathrm{ha}^{-1} \mathrm{mo}^{-1}$ with a mean of $29( \pm 3 \mathrm{SE}) \mathrm{kg} \mathrm{N} \mathrm{ha}^{-1} \mathrm{mo}^{-1} . \mathrm{NH}_{4}^{+}$was the dominant form of soil mineral $\mathrm{N}$ before incubation. On average, $\mathrm{NO}_{3}{ }^{-}$constituted $33 \%$ of the soil mineral $\mathrm{N}$ but in $70 \%$ of all cases no $\mathrm{NO}_{3}{ }^{-}$was detectable. Net $\mathrm{N}$ mineralization rates were neither affected by sward composition nor by mowing frequency (Table 3.3). Only fertilizer application influenced net $\mathrm{N}$ mineralization rates. In 2010, net $\mathrm{N}$ mineralization rates ranged from -29 to $105 \mathrm{~kg} \mathrm{~N} \mathrm{ha}^{-1} \mathrm{mo}^{-1}$ with a mean of 19 ( $\left.\pm 3 \mathrm{SE}\right) \mathrm{kg} \mathrm{N} \mathrm{ha}^{-1} \mathrm{mo}^{-1}$. Unlike in 2009, not only fertilization but also mowing frequency influenced net $\mathrm{N}$ mineralization rates: plots cut once per year showed larger net $\mathrm{N}$ mineralization rates than plots cut three times per year.

$\mathrm{N}$ supply in 2009 ranged from 15 to $1003 \mathrm{~kg} \mathrm{~N} \mathrm{ha}^{-1} \mathrm{yr}^{-1}$ with a mean of 278 ( $\pm 25 \mathrm{SE}$ ) $\mathrm{kg} \mathrm{N} \mathrm{ha}^{-1} \mathrm{yr}^{-1}$. In 2010, $\mathrm{N}$ supply ranged from 22 to $823 \mathrm{~kg} \mathrm{~N} \mathrm{ha}^{-1} \mathrm{yr}^{-1}$ with a mean of 217 ( \pm $18 \mathrm{SE}) \mathrm{kg} \mathrm{N} \mathrm{ha}^{-1} \mathrm{yr}^{-1}$. In both years, fertilization $(P=0.000)$ was the only factor influencing $\mathrm{N}$ supply. 
Table 3.3 Soil net N mineralization rates of a grassland under different management practices in the Solling Mountains, Germany.

\begin{tabular}{|c|c|c|c|c|c|c|c|c|}
\hline \multirow[b]{2}{*}{ Main factors } & \multirow[b]{2}{*}{ Treatments } & \multirow[b]{2}{*}{$\mathrm{n}$} & \multicolumn{3}{|c|}{2009} & \multicolumn{3}{|c|}{2010} \\
\hline & & & $\begin{array}{l}\text { Net } \mathrm{N} \\
\text { minerali } \\
(\mathrm{kg} \mathrm{N} \mathrm{ha}\end{array}$ & $\mathrm{SE}$ & $P$ & $\begin{array}{l}\text { Net } \mathrm{N} \\
\text { mineraliz } \\
(\mathrm{kg} \mathrm{N} \text { ha }\end{array}$ & $\mathrm{SE}$ & $P$ \\
\hline \multicolumn{3}{|c|}{ Sward composition } & & & 0.560 & & & 0.160 \\
\hline & control & 24 & $30.69 \mathrm{a}$ & 11. & & $16.75 \mathrm{a}$ & 7.87 & \\
\hline & dicot-enhanced & 24 & $25.56 \mathrm{a}$ & 8.42 & & $24.20 \mathrm{a}$ & 9.47 & \\
\hline & monocot-enhanced & 24 & $21.19 \mathrm{a}$ & 7.58 & & $18.05 \mathrm{a}$ & 5.88 & \\
\hline \multicolumn{2}{|c|}{ Mowing frequency } & & & & 0.400 & & & 0.018 \\
\hline & once per year & 36 & $24.77 \mathrm{a}$ & 7.6 & & $22.54 \mathrm{a}$ & 3.76 & \\
\hline & thrice per year & 36 & $26.83 \mathrm{a}$ & 7.6 & & $16.76 \mathrm{~b}$ & 2.79 & \\
\hline \multirow[t]{3}{*}{ Fertilization } & & & & & $<0.000$ & & & 0.009 \\
\hline & no & 36 & $13.50 \mathrm{~b}$ & 3.4 & & $15.48 \mathrm{~b}$ & 2.58 & \\
\hline & NPK & 36 & $38.12 \mathrm{a}$ & 9.8 & & $23.84 \mathrm{a}$ & 3.97 & \\
\hline
\end{tabular}

Mean values with different letter indicate significant differences among treatments within main factors or within an interaction of main factors

(Linear mixed effects models at $P \leq 0.05$ ). Treatment interactions that were not significant are not reported. 


\subsubsection{N RESPONSE EFFICIENCY, N UPTAKE EFFICIENCY AND N USE EFFICIENCY}

NRE in 2009 varied in a wide range from 10 to $488 \mathrm{~kg}$ biomass $\mathrm{kg} \mathrm{N}$ supply ${ }^{-1}$ with a mean of 48 ( $\pm 7 \mathrm{SE}) \mathrm{kg}$ biomass $\mathrm{kg} \mathrm{N}$ supply $^{-1}$. Fertilization was the main factor influencing NRE, with larger efficiency in unfertilized plots compared to fertilized plots (Table 3.4). Mowing frequency was the second important factor that explained the variance, with larger NRE in plots cut thrice than once per year. In 2010, NRE did not differ from 2009 with values ranging from 5 to $162 \mathrm{~kg}$ biomass $\mathrm{kg} \mathrm{N}$ supply $^{-1}$ and a mean of $42( \pm 4 \mathrm{SE}) \mathrm{kg}$ biomass $\mathrm{kg} \mathrm{N}$ supply ${ }^{-1}$. All three factors significantly affected NRE in 2010, with fertilization explaining the largest part of the variance followed by mowing frequency and sward composition. NRE was larger in unfertilized than in fertilized plots. The interaction between sward composition and mowing frequency indicated that regardless of mowing frequency, control plots showed an NRE comparable to the monocot- and dicot-enhanced plots that were cut thrice a year and that these NRE were larger than those in monocot- and dicot-enhanced plots cut once a year (Table 3.4). Within the covered range of $\mathrm{N}$ supply, NRE increased monotonically with decreasing N supply (Figure 3.1 a). 
Table 3.4 N response efficiency (NRE) of a grassland under different management practices in the Solling Mountains, Germany.

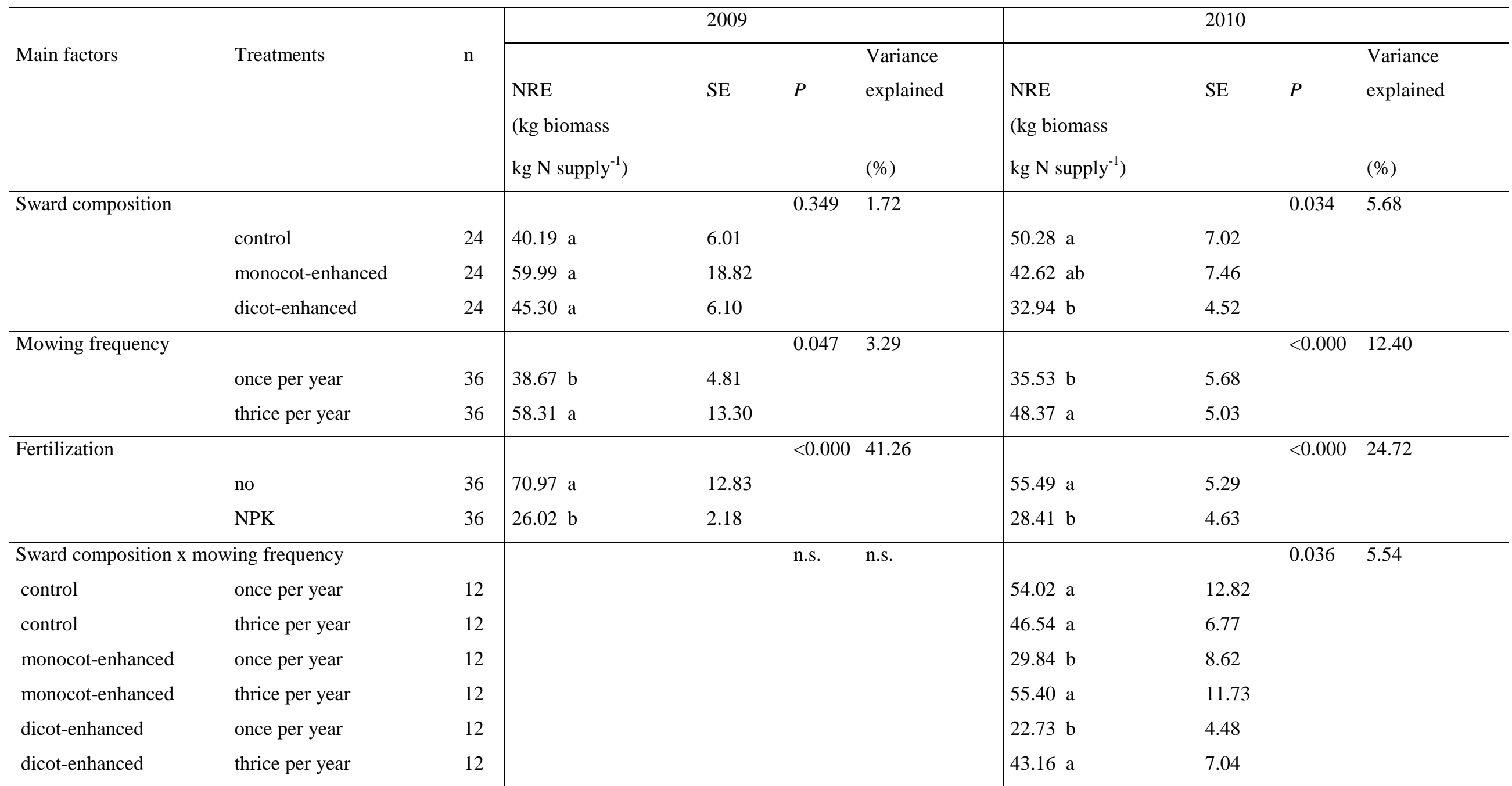

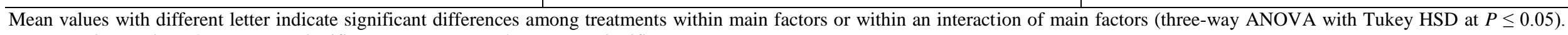

Treatment interactions that were not significant are not reported. n.s. = not significant. 

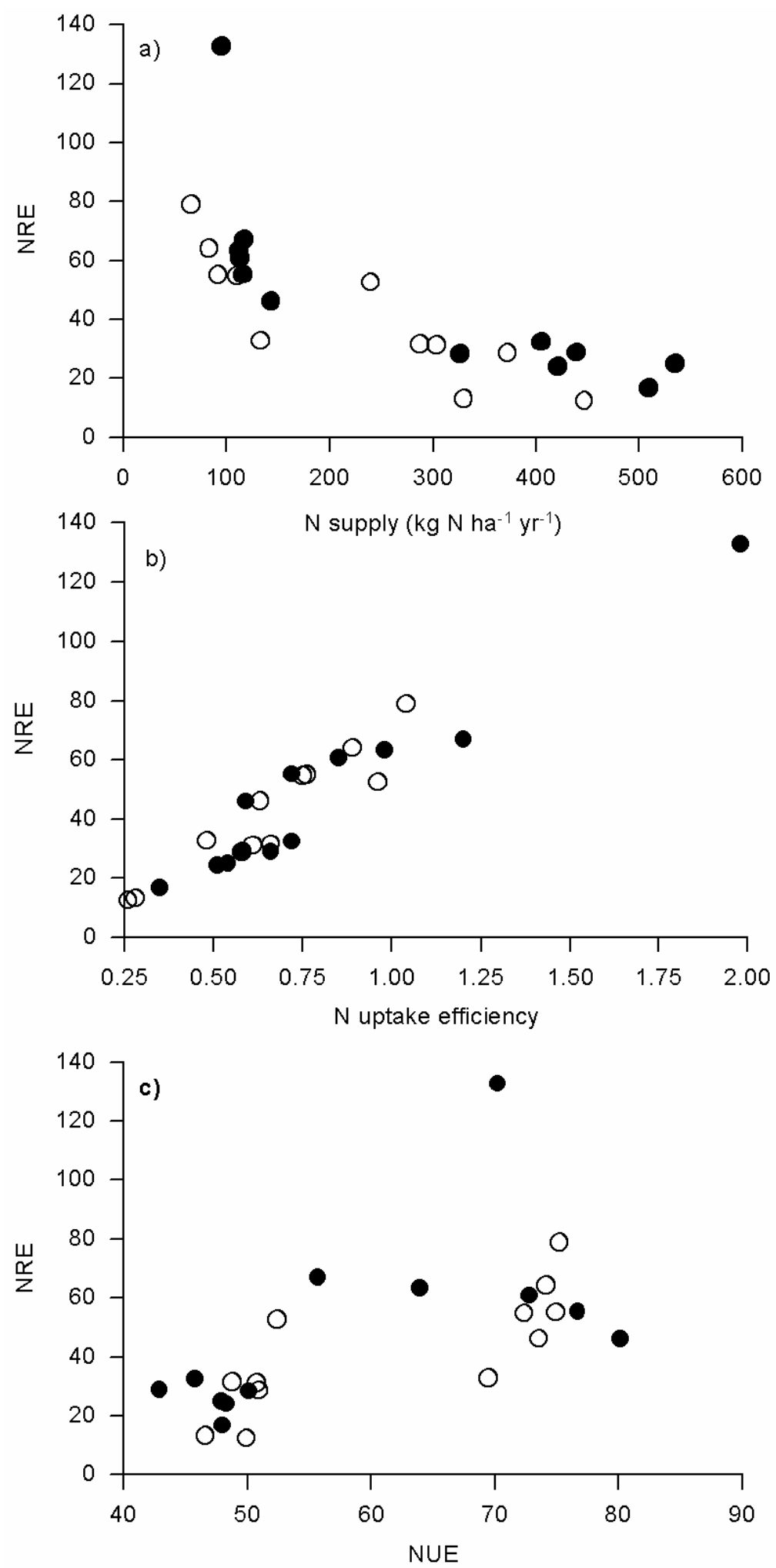

Figure 3.1 Trends between $\mathrm{N}$ response efficiency (NRE) and (a) $\mathrm{N}$ supply, (b) $\mathrm{N}$ uptake efficiency and (c) $\mathrm{N}$ use efficiency (NUE) of a grassland in the Solling Mountains, Germany. Each data point is the mean of six replicates per treatment $(\bullet$ for 2009 , $\circ$ for 2010). No statistical test was conducted because the $\mathrm{X}$ variables are components of the $\mathrm{Y}$ variable. 
$\mathrm{N}$ uptake efficiency in 2009 was largely affected by fertilization with larger efficiencies in unfertilized plots compared to fertilized plots (Table 3.5). Mowing frequency explained a small part of the variance with larger efficiencies in plots cut thrice per year than plots cut only once per year. In 2010, mowing frequency explained a larger part of the variance than fertilization. In addition, sward composition marginally influenced $\mathrm{N}$ uptake efficiency with a larger efficiency in control swards than monocot- and dicot-enhanced swards (Table 3.5). The pattern between NRE and $\mathrm{N}$ uptake efficiency showed increasing NRE with increasing $\mathrm{N}$ uptake efficiency (Figure $3.1 \mathrm{~b}$ ).

NUE was affected by all three factors in 2009 (Table 3.6). Fertilization was the most important factor influencing NUE. Unfertilized plots showed larger NUE than fertilized plots. Mowing was the second most important factor. Plots cut once per year showed larger NUE than plots cut thrice per year. This trend, however, was only significant for the unfertilized plots, based on fertilization and mowing interaction effect. Sward composition had the smallest influence with the largest NUE in monocot-enhanced swards, intermediate NUE in control swards and smallest NUE in dicot-enhanced swards. In 2010, fertilization was the only factor influencing NUE (Table 3.6). The trend between NRE and NUE was more scattered (Figure $3.1 \mathrm{c}$ ) than the pattern between NRE and N uptake efficiency (Figure $3.1 \mathrm{~b}$ ). 
Table 3.5 N uptake efficiency of a grassland under different management practices in the Solling Mountains, Germany.

\begin{tabular}{|c|c|c|c|c|c|c|c|c|c|c|}
\hline Year & & & & 2009 & & & & 2010 & & \\
\hline Main factors & Treatments & $\mathrm{n}$ & $\begin{array}{c}\text { N uptake } \\
\text { efficiency } \\
\\
\text { (kg plant } \mathrm{N} \\
\text { uptake } \\
\text { kg N supply }{ }^{-1} \text { ) }\end{array}$ & SE & $P$ & $\begin{array}{c}\text { Variance } \\
\text { explained } \\
\\
(\%) \\
\end{array}$ & $\begin{array}{c}\text { N uptake } \\
\text { efficiency } \\
\\
\text { (kg plant N } \\
\text { uptake } \\
\text { kg N supply }{ }^{-1} \text { ) }\end{array}$ & SE & $P$ & $\begin{array}{c}\text { Variance } \\
\text { explained } \\
\\
(\%) \\
\end{array}$ \\
\hline Sward composition & $\begin{array}{l}\text { control } \\
\text { monocot- } \\
\text { enhanced } \\
\text { dicot-enhanced }\end{array}$ & $\begin{array}{l}24 \\
24 \\
24 \\
\end{array}$ & $\begin{array}{l}0.65 \mathrm{a} \\
0.97 \mathrm{a} \\
0.80 \mathrm{a}\end{array}$ & $\begin{array}{l}0.08 \\
0.29 \\
0.10 \\
\end{array}$ & 0.372 & 2.13 & $\begin{array}{l}0.80 \mathrm{a} \\
0.65 \mathrm{a} \\
0.52 \mathrm{a}\end{array}$ & $\begin{array}{l}0.11 \\
0.10 \\
0.06\end{array}$ & 0.056 & 6.04 \\
\hline Mowing frequency & $\begin{array}{l}\text { once per year } \\
\text { thrice per year }\end{array}$ & $\begin{array}{l}36 \\
36 \\
\end{array}$ & $\begin{array}{l}0.60 \mathrm{~b} \\
1.01 \mathrm{a} \\
\end{array}$ & $\begin{array}{l}0.05 \\
0.20 \\
\end{array}$ & 0.003 & 9.91 & $\begin{array}{l}0.56 \mathrm{~b} \\
0.75 \mathrm{a} \\
\end{array}$ & $\begin{array}{l}0.09 \\
0.06 \\
\end{array}$ & $<0.001$ & 14.97 \\
\hline Fertilization & $\begin{array}{l}\text { no } \\
\text { NPK }\end{array}$ & $\begin{array}{l}36 \\
36 \\
\end{array}$ & $\begin{array}{l}1.05 \mathrm{a} \\
0.56 \mathrm{~b}\end{array}$ & $\begin{array}{l}0.20 \\
0.05 \\
\end{array}$ & $<0.001$ & 16.79 & $\begin{array}{l}0.76 \mathrm{a} \\
0.56 \mathrm{~b}\end{array}$ & $\begin{array}{l}0.07 \\
0.08\end{array}$ & 0.006 & 7.90 \\
\hline
\end{tabular}

Mean values with different letter indicate significant differences among treatments within main factors or within an interaction of main factors (three-way ANOVA at $P \leq 0.05$ ). Treatment interactions that were not significant are not reported. 
Table 3.6 N use efficiency (NUE) of a grassland under different management practices in the Solling Mountains, Germany.

\begin{tabular}{|c|c|c|c|c|c|c|c|c|c|c|}
\hline Year & & & & 2009 & & & & 2010 & & \\
\hline Main factors & Treatments & $\mathrm{n}$ & \begin{tabular}{|c} 
NUE \\
$\left(\right.$ kg biomass yield $\left.^{-1}\right)$ \\
kg plant $\mathrm{N}$ uptake $\left.^{-1}\right)$
\end{tabular} & SE & $P$ & $\begin{array}{c}\text { Variance } \\
\text { explained } \\
(\%)\end{array}$ & $\begin{array}{c}\text { NUE } \\
\left(\text { kg biomass yield }^{-1} \text { kg N supply }^{-1}\right)\end{array}$ & SE & $P$ & $\begin{array}{c}\text { Variance } \\
\text { explained } \\
(\%)\end{array}$ \\
\hline Sward composition & $\begin{array}{l}\text { control } \\
\text { monocot- } \\
\text { enhanced } \\
\text { dicot-enhanced }\end{array}$ & $\begin{array}{l}24 \\
24 \\
24 \\
\end{array}$ & $\begin{array}{l}59.10 \mathrm{ab} \\
61.55 \mathrm{a} \\
54.90 \mathrm{~b}\end{array}$ & $\begin{array}{l}2.71 \\
\\
3.39 \\
2.59 \\
\end{array}$ & 0.005 & 3.70 & $\begin{array}{l}63.07 \mathrm{a} \\
61.01 \mathrm{a} \\
60.60 \mathrm{a}\end{array}$ & $\begin{array}{l}2.70 \\
2.91 \\
2.33 \\
\end{array}$ & 0.179 & 0.71 \\
\hline Mowing frequency & $\begin{array}{l}\text { once per year } \\
\text { thrice per year }\end{array}$ & $\begin{array}{l}36 \\
36 \\
\end{array}$ & $\begin{array}{l}62.65 \mathrm{a} \\
54.39 \mathrm{~b} \\
\end{array}$ & $\begin{array}{l}2.67 \\
1.88 \\
\end{array}$ & $<0.001$ & 8.38 & $\begin{array}{l}61.12 \mathrm{a} \\
62.00 \mathrm{a} \\
\end{array}$ & $\begin{array}{l}2.15 \\
2.18 \\
\end{array}$ & 0.455 & 0.11 \\
\hline Fertilization & $\begin{array}{l}\text { no } \\
\text { NPK }\end{array}$ & $\begin{array}{l}36 \\
36 \\
\end{array}$ & $\begin{array}{l}69.88 \mathrm{a} \\
47.16 \mathrm{~b} \\
\end{array}$ & $\begin{array}{l}1.91 \\
0.78 \\
\end{array}$ & $<0.001$ & 63.42 & $\begin{array}{l}73.23 \mathrm{a} \\
49.88 \mathrm{~b}\end{array}$ & $\begin{array}{l}1.04 \\
0.71 \\
\end{array}$ & $<0.001$ & 83.06 \\
\hline $\begin{array}{l}\text { Fertilization x Mow } \\
\text { no } \\
\text { NPK } \\
\text { no } \\
\text { NPK }\end{array}$ & $\begin{array}{l}\text { g frequency } \\
\text { once per year } \\
\text { once per year } \\
\text { thrice per year } \\
\text { thrice per year }\end{array}$ & $\begin{array}{l}18 \\
18 \\
18 \\
18\end{array}$ & $\begin{array}{l}76.51 \mathrm{a} \\
48.78 \mathrm{c} \\
63.25 \mathrm{~b} \\
45.53 \mathrm{c}\end{array}$ & $\begin{array}{l}2.41 \\
0.99 \\
2.01 \\
1.10 \\
\end{array}$ & 0.003 & 3.07 & & & n.s. & \\
\hline
\end{tabular}

Mean values with different letter indicate significant differences among treatments within main factors or within an interaction of main factors (three-way ANOVA with Tukey HSD at $P \leq 0.05$ ).

Treatment interactions that were not significant are not reported. n.s. = not significant. 


\subsection{DISCUSSION}

\subsubsection{SOIL NET N MINERALIZATION, PLANT N UPTAKE AND BIOMASS YIELD}

The substantial increase of net $\mathrm{N}$ mineralization following first fertilization in 2009 was probably caused by a priming effect. Priming effects are changes in mineralization processes caused by moderate addition of nutrients to the soil, e.g. the input of a limiting factor for microbial biomass (Kuzyakov et al., 2000). Our experimental site had been used for hay production and cattle grazing since the early $20^{\text {th }}$ century. Only during the last five decades, a minimal fertilizer addition of $80 \mathrm{~kg} \mathrm{~N} \mathrm{ha}^{-1} \mathrm{yr}^{-1}$ was practiced. It is thus likely that the activity of microbial biomass was stimulated by the addition of $180 \mathrm{~kg} \mathrm{~N} \mathrm{ha}^{-1} \mathrm{yr}^{-1}$ at the beginning of our study. The reduction in net $\mathrm{N}$ mineralization rates in fertilized plots in the second year compared to the first year is also indicative of a priming effect, which has been suggested to be short term (Kuzyakov et al., 2000). While the addition of $\mathrm{N}$ fertilizer initially stimulates mineralization after a long period of $\mathrm{N}$ limitation, regular $\mathrm{N}$ additions may not increase $\mathrm{N}$ cycling continuously (Hassink, 1994). The decreased net $\mathrm{N}$ mineralization rates with increased mowing frequency in the second year could be due to reduced input of organic matter into the soil as a consequence of the removal of biomass (Holt, 1997; Mikola et al., 2001; Northup et al., 1999; Sankaran and Augustine, 2004). Alternatively, it is possible that the reduced net $\mathrm{N}$ mineralization rates on the plots cut thrice per year could also be caused by large $\mathrm{N}$ immobilization by the microbial community, which may result from increased rhizodeposition following defoliation (Holland et al., 1996). Such an explanation is corroborated by the findings of Guitian and Bardgett (2000) who observed increased soil microbial biomass caused by defoliation of grass.

Within the range of $\mathrm{N}$ supply covered in our study, the linear increase of plant $\mathrm{N}$ uptake was reflected by similar trends of increases in aboveground biomass yield and plant $\mathrm{N}$ concentrations (data not shown). The enhanced plant $\mathrm{N}$ uptake by more frequent mowing could be possibly due to 1 ) increased root-to-shoot ratio by intensive mowing (Kammann et al., 1998; Mooney and Winner, 1991), which may then result in large nutrient uptake by plants, and 2) defoliation-induced increase in resource allocation to shoots, as reported by Guitian and Bardgett (2000) for grazing-tolerant grasses. However, for our study site, fineroot biomass and root length density measured in the control swards in September 2009 were not affected by mowing frequency (Rose et al., 2011a). Thus, it is likely that our observed 
increased plant $\mathrm{N}$ uptake by more frequent mowing is due to increased resource allocation to shoots and overcompensatory response to defoliation (Ferraro and Oesterheld, 2002; Guitian and Bardgett, 2000).

Our finding that the dicot-enhanced swards (with equal proportions of dicots and monocots) on did not result in a larger biomass yield compared to control and monocotenhanced swards contrasts to the findings of Hector et al. (1999) and Weigelt et al. (2009) who reported a reduction of aboveground biomass with loss of functional groups in European grasslands. Furthermore, the number of plant species was not responsible for differences in biomass yield. Dicot-enhanced and monocot-enhanced swards showed no significant differences in biomass yield although the numbers of species were different, which is not consistent to the biodiversity-productivity theory (e.g. Hector et al., 1999; Tilman et al., 1996; Weigelt et al., 2009). However, as we only considered harvestable, aboveground biomass, inclusion of belowground biomass may lead to different results.

\subsubsection{N RESPONSE EFFICIENCY}

To our knowledge, published information about NRE in grassland ecosystems is extremely limited and definitions of NRE are not consistent in literature (Aerts, 1990; Vitousek, 1982; Xu et al., 2012). Unlike other NRE and NUE studies that used litterfall N concentrations as an index of $\mathrm{N}$ availability (Vitousek, 1982) or measured mineral $\mathrm{N}$ concentrations in soil (Bridgham et al., 1995), we used in-situ measured net $\mathrm{N}$ mineralization rates as an index of soil plant-available N (Hart et al., 1994). Our measured NRE values were smaller than those reported by Yuan et al. (2006) for a semi-arid grassland in China. Apart from site-specific differences between our and their study sites, the differences in NRE could also be due to the different measures used for $\mathrm{N}$ supply and biomass production. On the one hand, our estimate of $\mathrm{N}$ supply included fertilization, $\mathrm{N}$ deposition and cumulative net $\mathrm{N}$ mineralization rates during the growing season, resulting in large values of $\mathrm{N}$ supply and thus small NRE. On the other hand, Yuan et al. (2006) included not only aboveground but also belowground biomass production, which would lead to large NRE.

Our finding that NRE was largely influenced by fertilization was similar with those of Hiremath and Ewel (2001) who reported that NRE (which they termed ecosystem-level NUE) was negatively correlated with mean annual net nitrification rate, used as an index of soil $\mathrm{N}$ 
supply. The smaller NRE of the fertilized than unfertilized plots was caused by decreases in both $\mathrm{N}$ uptake efficiency and NUE. The monotonic increase in NRE with decreasing $\mathrm{N}$ supply was also consistent with the findings of Yuan et al. (2006), and was unlike the unimodal curve between NRE and soil net $\mathrm{N}$ mineralization rates (ranging from 25-85 kg N ha ${ }^{-1} \mathrm{yr}^{-1}$ ) modelled by Bridgham et al. (1995) for temperate forests. This also supports the suggestion that the unimodal NRE curve may only be applicable for ecosystems with small $\mathrm{N}$ availability (Yuan et al., 2006). The second most important factor influencing NRE was mowing frequency. The increased NRE in plots cut thrice per year was largely due to increasing $\mathrm{N}$ uptake efficiency since NUE was either showing the opposite trend or not affected by mowing at all. The increased $\mathrm{N}$ uptake efficiency in plots cut thrice per year was caused by increased biomass yield and $\mathrm{N}$ concentration in biomass.

Finally, sward composition influenced NRE although to a lesser extent than fertilization and mowing frequency. Compared to the influence of sward compositions on biomass yield, where dicot-enhanced swards did not differ from control swards, the influence of sward composition on NRE was more pronounced and explained a larger part of the variance. The trends of NRE and N uptake efficiency among sward compositions were similar whereas NUE exhibited either opposite patterns or was not affected by sward composition. This emphasizes that NRE of the different sward compositions was influenced more by $\mathrm{N}$ uptake efficiency rather than by NUE and is contrary to the findings of van Ruijven and Berendse (2005) who observed an increasing NUE with increasing species richness in a grassland system without legumes. In our study site, legumes were only present in the control(1-4\% abundance) and dicot-enhanced (4-9\%) swards. The presence of legumes however cannot support the pattern of differences in NRE among sward compositions but instead the interaction between sward composition and mowing frequency. For example, since we did not account the $\mathrm{N}$ input from $\mathrm{N}$-fixing legumes in our NRE calculation, this could have led to an underestimation of $\mathrm{N}$ supply and thus an overestimation of NRE in the control and dicotenhanced swards. Instead we found that the monocot-enhanced swards (no legumes) had comparable NRE with the control and dicot-enhanced swards all cut thrice a year and the lowest NRE was found in both monocot- and dicot-enhanced swards cut once per year (Table 3.4). The patterns of NRE cannot also be explained by the difference in plant species number. NRE of monocot-enhanced swards which had the smallest number (12-13) of species did not significantly differ from NRE of dicot-enhanced swards (17 species). According to Roy (2001) $90 \%$ of the biodiversity effect on productivity is reached at five species, implying that 
the difference in plant species in our experiment is larger than the threshold number and effects might not be detectable (Wrage et al., 2011). In contrast to the number of species, the proportions of plant functional groups did have a significant impact on NRE. The proportions of $\sim 30 \%$ dicots and $\sim 70 \%$ monocots found in the control swards showed the largest NRE. We think that over the past decades $\mathrm{N}$-limited conditions and prevailing management practices have led to an equilibrium in this grassland ecosystem in which optimal proportions of monocots and dicots developed to maximize NRE. As a result, an artificial increase in the proportion of dicots as well as in the proportion of monocots would lead to a smaller NRE. Thus, our results suggest that in addition to the effect of life-form diversity (Hiremath and Ewel, 2001) also the proportions of different plant functional groups affect NRE of an ecosystem.

\subsection{CONCLUSIONS}

Our results show that management largely influenced NRE whereas plant functional group diversity only played a minor role. Fertilization decreased NRE due to decreases in both $\mathrm{N}$ uptake efficiency and NUE whereas mowing frequency and sward composition affected NRE through N uptake efficiency rather than NUE. The proportions of monocots and dicots in the control plots that were the result of long-term management practices had the largest NRE. Deviations from these proportions - even to more balanced proportions of monocots and dicots - decreased NRE. Our results show that NRE gives important insights in how different management can be evaluated to come up with a more sustainable grassland management. However, our study can only be a first step towards definite recommendations and NRE should be combined with an economic analysis before advices to farmers can be made. 


\section{CHAPTER}

4

NITROGEN RETENTION EFFICIENCY

AND NITROGEN LOSSES OF A MANAGED

AND PHYTODIVERSE TEMPERATE

GRASSLAND 


\subsection{AbSTRaCT}

Maintaining nitrogen $(\mathrm{N})$ retention efficiency is crucial in minimizing $\mathrm{N}$ losses when intensifying management of temperate grasslands. Our aim was to evaluate how grassland management practices and sward compositions affect $\mathrm{N}$ retention efficiency $(1-\mathrm{N}$ losses $\div$ soil available $\mathrm{N}$ ), defined as the efficiency with which soil available $\mathrm{N}$ is retained in an ecosystem. A three-factorial grassland management experiment was established with two fertilization treatments (no fertilization and combined nitrogen, phosphorus and potassium fertilization), two mowing frequencies (cut once and thrice per year) and three sward compositions (control, monocot- and dicot-enhanced swards). We measured $\mathrm{N}$ losses as leaching and nitrous oxide emissions, and soil available $\mathrm{N}$ as gross $\mathrm{N}$ mineralization rates. Fertilization was the dominant factor influencing $\mathrm{N}$ losses and $\mathrm{N}$ retention efficiency; it increased $\mathrm{N}$ losses due to increased nitrification and decreased microbial $\mathrm{N}$ immobilization, and consequently decreased $\mathrm{N}$ retention efficiency. Intensive mowing partly dampened high $\mathrm{N}$ losses following fertilization. Sward compositions influenced $\mathrm{N}$ retention efficiency but not $\mathrm{N}$ losses: control swards that have developed under decades of extensive management practices had the highest $\mathrm{N}$ retention efficiency whereas monocot-enhanced sward had the lowest $\mathrm{N}$ retention efficiency. Across treatments, $\mathrm{N}$ retention efficiency was highly correlated with microbial $\mathrm{NH}_{4}{ }^{+}$immobilization and microbial biomass and only marginally correlated with plant $\mathrm{N}$ uptake, underlining the importance of microbial $\mathrm{N}$ retention in the soil-plant system. Such pathway is reflected in $\mathrm{N}$ retention efficiency but not in indices commonly used to reflect plant response. As $\mathrm{N}$ retention efficiency was able to capture the effects of sward compositions and fertilization whereas $\mathrm{N}$ losses were only sensitive largely to fertilization, $\mathrm{N}$ retention efficiency as a better index than just $\mathrm{N}$ losses when evaluating environmental sustainability of sward compositions and management practices of grasslands.

Keywords: nitrate leaching, dissolved organic nitrogen, nitrous oxide emissions, gross $\mathrm{N}$ mineralization, microbial immobilization, ${ }^{15} \mathrm{~N}$ pool dilution, functional group diversity 


\subsection{INTRODUCTION}

Nitrogen $(\mathrm{N})$ is an essential plant nutrient that limits primary production in many ecosystems, making the use of $\mathrm{N}$ fertilizers widespread in agricultural ecosystems (Vitousek and Howarth, 1991). As a result of the growing global population, a more intensive agricultural production and hence an increase in the use of $\mathrm{N}$ fertilizers can be expected in the near future (Galloway et al., 2008). Agricultural intensification is, however, accompanied by negative environmental impacts: considerable amounts of applied fertilizer $\mathrm{N}$ can be lost through nitrate $\left(\mathrm{NO}_{3}{ }^{-}\right)$leaching or gaseous emissions, e.g. in the form of nitrous oxide $\left(\mathrm{N}_{2} \mathrm{O}\right)$. Leaching of $\mathrm{NO}_{3}{ }^{-}$can be a threat to ground- and surface-water quality (Di and Cameron, 2002) whereas $\mathrm{N}_{2} \mathrm{O}$ is an important greenhouse gas that also contributes to the depletion of stratospheric ozone (Schlesinger, 2009). In agriculture, maintaining soil quality and high yields while minimizing $\mathrm{N}$ losses can only be achieved through efficient retention of $\mathrm{N}$ in the plant-soil system, i.e. available mineral $\mathrm{N}$ should be taken up by plants or immobilized by the microbial community before it is potentially lost through the microbial processes of nitrification and denitrification. $\mathrm{N}$ retention efficiency, defined as the efficiency with which available $\mathrm{N}$ is retained in an ecosystem, is thus an important parameter to evaluate the sustainability of a land use system.

In temperate grasslands, $\mathrm{N}$ retention efficiency may be influenced by management practices and plant diversity (Christian and Riche, 1998; Flechard et al., 2005; Jones et al., 2005). Application of $\mathrm{N}$ fertilizer typically increases $\mathrm{N}$ losses (e.g. Christian and Riche, 1998, Jones et al., 2005) whereas mowing can lead to a more effective plant $\mathrm{N}$ uptake caused by overcompensatory regrowth of plants (Ferraro and Oesterheld, 2002) or by a denser root system (Kammann et al., 1998). A more diverse grassland community may have a higher $\mathrm{N}$ retention through complementary resource use, e.g. due to different rooting depths of various plant communities, uptake of different forms of $\mathrm{N}$, or $\mathrm{N}$ uptake at different times of the year (e.g. Hooper and Vitousek, 1998). It has been reported that increasing plant species diversity reduces the amount of extractable soil mineral N (e.g. Ewel et al., 1991; Niklaus et al., 2001; Tilman et al., 1996). However, most studies have been carried out in artificial and intensively weeded grassland plots, making it difficult to compare with permanent, managed grassland. Furthermore, soil $\mathrm{NO}_{3}{ }^{-}$concentrations are not directly related to $\mathrm{NO}_{3}{ }^{-}$leaching, complicating their interpretation (Scherer-Lorenzen et al., 2003). To our knowledge, there are only two studies that directly quantified $\mathrm{NO}_{3}{ }^{-}$leaching losses as a function of plant diversity (Hooper 
and Vitousek, 1997; Scherer-Lorenzen et al., 2003) and only one study investigated biodiversity effects on leaching of dissolved organic N (DON) (Dijkstra et al., 2007). No study had been conducted on the effects of mowing on $\mathrm{N}$ leaching. Moreover, the impact of plant functional group diversity on $\mathrm{N}_{2} \mathrm{O}$ emissions from soils has so far received only little research attention. In our earlier study, conducted in a 20-year established, grazed grassland in Germany, $\mathrm{N}_{2} \mathrm{O}$ and $\mathrm{NO}$ fluxes were not affected by plant species composition but by different livestock grazers (Hoeft et al., 2012). Reduced $\mathrm{N}_{2} \mathrm{O}$ fluxes with increase in mowing frequency have been reported for a 50-year established, non-grazed grassland in Germany (Kammann et al., 1998).

In the present study, our goal was to evaluate how $\mathrm{N}$ retention efficiency is influenced by different management treatments (i.e. fertilization and mowing frequency) and sward compositions (differing in plant functional group compositions and plant species richness) in a temperate grassland. We were especially interested in the question whether management or manipulation of plant functional groups can compensate the high $\mathrm{N}$ losses that are frequently observed following fertilizer application. We tested the following hypotheses: 1) fertilization results to larger $\mathrm{N}$ losses and lower $\mathrm{N}$ retention efficiency than without fertilization; 2) intensive mowing frequency decreases $\mathrm{N}$ losses and increases $\mathrm{N}$ retention efficiency; 3) swards with equal proportions of various plant functional groups would have low $\mathrm{N}$ losses and high $\mathrm{N}$ retention efficiency due to complementary resource use.

\subsection{MATERIAL AND METHODS}

\subsubsection{APPROACH}

We first developed an index that can be used for the evaluation of the ecosystem property, $\mathrm{N}$ retention efficiency. Aber and collegues (1998) use the following index for $\mathrm{N}$ retention efficiency: 1 - ( $\mathrm{N}$ outputs $\div \mathrm{N}$ inputs)

While this index may work well for forest ecosystems where long-term data of $\mathrm{N}$ input and output have been collected, it does not account for changes in soil $\mathrm{N}$ cycling caused by management in agricultural systems. For example, when $\mathrm{N}$ fertilizer is applied, large proportions of applied mineral $\mathrm{N}$ are immediately immobilized by the soil microbial community (Bristow et al., 1987), a process which typically exceeds plant N uptake (Jackson 
et al., 1989). This microbially-assimilated $\mathrm{N}$ will become again available through microbial turnover which occurs within about two weeks for a temperate grassland (Corre et al., 2002), and thus soil available $\mathrm{N}$ is usually larger than the mere external $\mathrm{N}$ input by fertilization. In the present study, we account for such processes by using an index of available $\mathrm{N}$ that is actively cycling in the soil and is available to plants and microbial biomass, and thus we used the following index for $\mathrm{N}$ retention efficiency:

$\mathrm{N}$ retention efficiency $=$

$1-\left(\mathrm{N}\right.$ losses $\left(\mathrm{mg} \mathrm{N} \mathrm{m}^{-2} \mathrm{~d}^{-1}\right) \div$ gross $\mathrm{N}$ mineralization rates $\left.\left(\mathrm{mg} \mathrm{N} \mathrm{m}^{-2} \mathrm{~d}^{-1}\right)\right)$

where the $\mathrm{N}$ losses were the sum of average daily $\mathrm{NO}_{3}{ }^{-}$and DON leaching rates $\left(\mathrm{mg} \mathrm{N} \mathrm{m}^{-2} \mathrm{~d}^{-}\right.$ ${ }^{1}$ ) and mean daily $\mathrm{N}_{2} \mathrm{O}$ emissions rates $\left(\mathrm{mg} \mathrm{N} \mathrm{m}^{-2} \mathrm{~d}^{-1}\right)$; gross $\mathrm{N}$ mineralization rates were measured once during the growing season.

\subsubsection{STUDY SITE}

The study (which is part of the grassland manipulation (GRASSMAN) experiment) was conducted on a moderately species-rich grassland in the Solling uplands of Lower

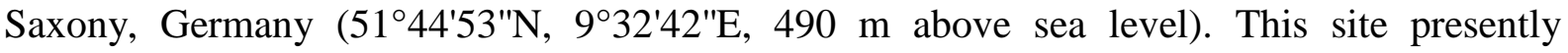
belongs to the Relliehausen experimental farm and has been used for grazing or hay making for at least 100 years (Geological Map of Prussia 1910 (based on the topographic inventory of 1896), topographic maps of Sievershausen and Neuhaus/Solling 1924, 1956 and 1974, Braunschweigische Landesaufnahme, $18^{\text {th }}$ century). Before the experiment started, the site was managed extensively by moderate application of fertilizer (80 $\left.\mathrm{kg} \mathrm{N} \mathrm{ha}^{-1} \mathrm{y}^{-1}\right)$, occasional lime application, overseeding with high value forage species and cattle grazing (farm records Relliehausen since 1966). Prior to the experiment, vegetation was classified as a montane, semi-moist Lolio-Cynosuretum. Mean annual precipitation is $1031 \mathrm{~mm}$ and mean annual temperature is $6.9^{\circ} \mathrm{C}$ (Deutscher Wetterdienst 1961 - 1990). The soil is a Haplic Cambisol (WRB 2006) that developed on loess sediments with a loamy silt texture overlying weathered Triassic sandstone. 


\subsubsection{EXPERIMENTAL SET UP}

The GRASSMAN experiment was set up in a three-factorial design, including three sward compositions, two mowing frequencies (cut once and thrice a year), and two fertilization treatments (with combined $\mathrm{N}$, phosphorus $(\mathrm{P})$ and potassium $(\mathrm{K})$ addition, and no fertilization). In 2008, three sward compositions were established: monocot-enhanced swards where herbicide mixture against dicotyledons (Starane ${ }^{\circledR}$ (active ingredients: Fluoroxypyr and Triclopyr) and Duplosan KV (active ingredients: Mecoprop- $\mathrm{B}())$ was applied and resulted in a reduced herb and legume abundance; dicot-enhanced swards where herbicide mixture against monocotyledons (Select 240 EC® by Stähler (active ingredients: Clethodim)) was applied and resulted in a reduced grass abundance: and untreated control swards. The monocot-enhanced swards had 12-13 species, 91-93\% grasses, 7-9\% herbs and 0\% legumes. The dicot-enhanced swards had 17 species, 40-47\% grasses, 49-53\% herbs and 4-9\% legumes. The control swards had 16-18 species, $68-76 \%$ grasses, $21-31 \%$ herbs and 1-4\% legumes) (Petersen et al., 2012). In 2008, all swards were mowed once and the fertilized plots received $50 \mathrm{~kg} \mathrm{~N} \mathrm{ha}^{-1}$. Mowing and fertilization treatments started in 2009. Half of the plots were mown once per year and the other half of the plots were cut three times per year. Mowing was conducted in July for plots with one cut per year and in May, July and September for plots with three cuts per year. A Haldrup (C) forage combine harvester with a cutting height of $7 \mathrm{~cm}$ was used. Half of the plots were fertilized with $180 \mathrm{~kg} \mathrm{~N} \mathrm{ha}^{-1} \mathrm{y}^{-1}, 30 \mathrm{~kg}$ $\mathrm{P} \mathrm{ha}^{-1} \mathrm{y}^{-1}$ and $100 \mathrm{~kg} \mathrm{~K} \mathrm{ha}^{-1} \mathrm{y}^{-1}$. Mineral N fertilizer (calcium ammonium nitrate N27) was split into two equal applications per year (April and May 2009 and April and June 2010) while the combined P and K fertilizer was applied once a year (June 2009 and 2010). The full-factorial combination of these treatments (three sward compositions, two mowing frequencies, and two fertilization treatments) led to twelve treatment combinations, each replicated six times. The resulting 72 plots $(15 \mathrm{~m} \mathrm{x} 15 \mathrm{~m}$ each) were arranged in a Latin rectangle.

\subsubsection{SOIL CHARACTERISTICS}

A summary of soil characteristics is presented in Table 4.1. In spring 2008, soil samples were taken at nine sampling points per plot (0.01-0.1 m depth), pooled, oven-dried $\left(40^{\circ} \mathrm{C}\right)$ for a week and sieved $(2 \mathrm{~mm})$. Soil bulk density was measured in summer 2009 from 
undisturbed soil cores (0.00-0.05 m) using the soil core method (Blake and Hartge, 1986). Particle size distribution was determined by wet sieving $(>20<630 \mu \mathrm{m})$ and pipette methods $(\leq 20 \mu \mathrm{m})$ after pre-treatment with $30 \% \mathrm{H}_{2} \mathrm{O}_{2}$ and $4 \%$ Na-dithionite-citrate solution. Cation exchange capacity (CEC) was determined using percolation with $0.1 \mathrm{~mol} \mathrm{BaCl}_{2}$ (König and Fortmann, 1996). Cations in percolates were measured with Inductively Coupled Plasma Optical Emission Spectrometry (ICP-OES; Optima 3000 XL, Perkin Elmer, Rodgau, Germany). Base saturation was calculated as the percentage exchangeable base cations of the CEC. Soil $\mathrm{pH}$ was measured from a soil-to-distilled water ratio of 1:2. Total concentrations of carbon $(\mathrm{C})$ and $\mathrm{N}$ were determined from ground soil samples using $\mathrm{CN}$ elemental analyzer (Vario EL III, Elementar, Hanau, Germany).

Table 4.1 Soil characteristics in the Ah horizon (0.01-0.1 m) of a Haplic Cambisol of a grassland site in the Solling Mountains, Germany.

\begin{tabular}{|c|c|c|c|}
\hline Physical and chemical ${ }^{*}$ properties & Mean & SE & $\mathrm{n}$ \\
\hline Sand $(\%)$ & 21.62 & 1.2 & 18 \\
\hline Silt $(\%)$ & 66.53 & 1.3 & 18 \\
\hline Clay $(\%)$ & 11.85 & 0.8 & 18 \\
\hline Bulk density $\left(\mathrm{g} \mathrm{cm}^{-3}\right)$ & 0.79 & 0.01 & 72 \\
\hline Cation exchange capacity $\left(\mathrm{mmol}_{\mathrm{c}} \mathrm{kg}^{-1}\right)$ & 169.00 & 5.2 & 72 \\
\hline Base saturation (\%) & 37.18 & 1.4 & 72 \\
\hline $\mathrm{pH}\left(1: 2 \mathrm{H}_{2} \mathrm{O}\right)$ & 5.34 & 0.03 & 72 \\
\hline Carbon : Nitrogen ratio & 12.60 & 0.04 & 72 \\
\hline
\end{tabular}

\subsubsection{GROSS N TRANSFORMATION RATES AND MICROBIAL BIOMASS}

In September 2010, gross N mineralization and nitrification rates were measured using ${ }^{15} \mathrm{~N}$ pool dilution techniques (Davidson et al., 1991). These were measured from five replicates of the three sward compositions and two fertilization treatments that were all cut once per year (totalling to 5 × $3 \times 2=30$ plots). At each sampling plot, two intact soil cores ( 8 
$\mathrm{cm}$ in diameter and $5 \mathrm{~cm}$ in height) were injected with $\left({ }^{15} \mathrm{NH}_{4}\right)_{2} \mathrm{SO}_{4}$ solution (for gross mineralization and $\mathrm{NH}_{4}{ }^{+}$consumption rates) and another two intact soil cores were injected with $\mathrm{K}^{15} \mathrm{NO}_{3}$ solution (for gross nitrification rates). Each soil core received five 1-ml injections containing either $29 \mu \mathrm{g} \mathrm{N} \mathrm{ml}^{-1}\left(\left({ }^{15} \mathrm{NH}_{4}\right)_{2} \mathrm{SO} 4\right)$ or $28 \mu \mathrm{g} \mathrm{N} \mathrm{ml}^{-1}\left(\mathrm{~K}^{15} \mathrm{NO}_{3}\right)$ with $99 \%$ ${ }^{15} \mathrm{~N}$ enrichment, which was equivalent to a rate of 0.78 and $0.73 \mu \mathrm{g}{ }^{15} \mathrm{~N} \mathrm{~g}^{-1}$, respectively. Ten minutes after ${ }^{15} \mathrm{~N}$ injection, the soil of each labelled pair was extruded out of the core, mixed thoroughly, and part of it was added to a polyethylene bottle containing $150 \mathrm{ml}$ of $0.5 \mathrm{~mol} \mathrm{~L}^{-1}$ $\mathrm{K}_{2} \mathrm{SO}_{4}$ (approximately 1:3 ratio of fresh soil to $\mathrm{K}_{2} \mathrm{SO}_{4}$ solution) ( $T_{0}$ cores). The other soil core of the labelled pair was put in a plastic bag, inserted back into the soil to incubate in situ for one day, and extracted in the same manner ( $T_{1}$ cores). The bottles containing soil and $\mathrm{K}_{2} \mathrm{SO}_{4}$ solution were shaken for one hour; the extracts were filtered through pre-washed filter papers ( $4 \mu \mathrm{m}$ nominal pore size) and stored at $-18^{\circ} \mathrm{C}$ until analysis. $\mathrm{NH}_{4}{ }^{+}$and $\mathrm{NO}_{3}{ }^{-}$concentrations of the extracts were measured using continuous flow injection colorimetry (CFIC), in which $\mathrm{NH}_{4}{ }^{+}$was determined by Berthelot reaction method (Skalar Method 155-000) and $\mathrm{NO}_{3}{ }^{-}$by copper-cadmium reduction method (with $\mathrm{NH}_{4} \mathrm{Cl}$ buffer but without ethylenediamine tetraacetic acid; Skalar Method 461-000). Gravimetric moisture content was determined from all soil samples by oven-drying at $105^{\circ} \mathrm{C}$ for 24 hours, and these values were used to calculate the dry mass of extracted soil samples. The ${ }^{15} \mathrm{~N}$ enrichment of $\mathrm{NH}_{4}{ }^{+}$and $\mathrm{NO}_{3}{ }^{-}$pools were determined by ${ }^{15} \mathrm{~N}$ diffusion with blank correction as described in details by Corre and Lamersdorf (2004). ${ }^{15} \mathrm{~N}$ analysis was done using isotope ratio mass spectrometry (Finigan MAT, Bremen, Germany). Gross $\mathrm{N}$ mineralization, gross nitrification and $\mathrm{NH}_{4}{ }^{+}$consumption rates were estimated using the ${ }^{15} \mathrm{~N}$ pool dilution equations described by Davidson et al. (1991) of which also $\mathrm{NH}_{4}{ }^{+}$immobilization rate was calculated as the difference between gross rates of $\mathrm{NH}_{4}{ }^{+}$consumption and nitrification.

For microbial biomass $\mathrm{C}$ and $\mathrm{N}$ determination, we used the fumigation-extraction method (Brookes et al., 1985). Part of the soil from the $\mathrm{T}_{1}$ cores were fumigated with chloroform for 5 days and extracted with $0.5 \mathrm{~mol} \mathrm{~L}^{-1} \mathrm{~K}_{2} \mathrm{SO}_{4}$ as described above. Organic $\mathrm{C}$ concentrations of the extracts from fumigated and the corresponding unfumigated soils were analyzed by UV-enhanced persulfate oxidation using a Dohrman DC-80 Carbon analyzer with an infrared detector (Rosemount Analytical Division, Santa Clara, California, USA). Similarly, total $\mathrm{N}$ concentrations of the extracts were determined by persulfate digestion, which involves oxidation of $\mathrm{NH}_{4}{ }^{+}$and organic $\mathrm{N}$ to $\mathrm{NO}_{3}^{-}$while $\mathrm{NO}_{3}^{-}$remains unchanged, followed by colorimetric analysis of $\mathrm{NO}_{3}{ }^{-}$as described above. Microbial biomass $\mathrm{C}$ and $\mathrm{N}$ 
were calculated as the difference in organic $\mathrm{C}$ and total $\mathrm{N}$ concentrations between fumigated and unfumigated soils divided by $k_{C}=0.45$ for microbial biomass $\mathrm{C}$ and $k_{N}=0.68$ for microbial biomass $\mathrm{N}$.

\subsubsection{WATER BALANCE, $\mathrm{N}$ LEACHING LOSSES AND $\mathrm{N}_{2} \mathrm{O}$ EMISSIONS}

$\mathrm{N}$ leaching losses were sampled monthly. No soil water can be withdrawn from the lysimeters during January - February 2009 and 2010 (mean temperature below $0^{\circ} \mathrm{C}$ ) and during August 2009 and 2010 (dry months). We installed one suction cup lysimeter (P80 ceramic, maximum pore size $1 \mu \mathrm{m}$; CeramTec AG, Marktredwitz, Germany) per plot at a depth between 0.5-0.6 m, which was beyond the rooting depth (see below), three months prior to the first sampling. Soil solution was sampled over a month by applying a suction of 600 $\mathrm{hPa}$ to the lysimeters and was collected into a glass bottle placed in a dark bucket that was dug in the soil. Immediately after field collection, the water samples were stored at $-18^{\circ} \mathrm{C}$ until analysis. $\mathrm{NH}_{4}{ }^{+}$and $\mathrm{NO}_{3}{ }^{-}$concentrations of the soil water were measured using CFIC as described above. Total dissolved N (TDN) concentrations were determined using CFIC by UV-persulfate oxidation followed by hydrazine sulphate reduction (Skalar Method 473-000). DON was calculated as the difference between TDN and $\mathrm{NH}_{4}^{+}+\mathrm{NO}_{3}{ }^{-}$. There was no detectable $\mathrm{NH}_{4}{ }^{+}$in the leaching water, and thus leaching losses was mainly composed of $\mathrm{NO}_{3}{ }^{-}$ and DON. Monthly $\mathrm{NO}_{3}{ }^{-}$and DON leaching losses were calculated by multiplying their concentrations in the monthly sampled soil water with the total drainage flux of the month.

Drainage flux was calculated on a daily time step using the 1D hydrological model BROOK90 (Federer et al., 2003), which was parameterized with the prevailing site conditions. Input climatic data (daily total precipitation, minimum/maximum air temperature, solar radiation, vapour pressure and wind speed) were taken from a meteorological station at the study site. Daily evapotranspiration $(\mathrm{ET}=$ evaporation + transpiration + interception) was calculated from the meteorological data and vegetation properties using the approach of Shuttleworth and Wallace (1985). The seasonal course of the leaf area index, used for the calculation of ET, was derived from average biomass productions according to Rose et al. (2011a). Root uptake of water from the soil was depth-partitioned by assuming that root distribution decreases exponentially within $0.3-\mathrm{m}$ rooting depth with $70 \%$ of the roots in the top 0.1-m depth. The vertical water movement in the soil was simulated using the Richards 
equation, from which the relationships between matrix potential, water content and hydraulic conductivity for the soil texture (as described by Clapp and Hornberger, 1978) similar to that in our study site were used. To validate the model, we compared the modelled soil matrix potential with the measured matrix potential. Matrix potential was measured monthly using tensiometers (P80 ceramic, maximum pore size $1 \mu \mathrm{m}$; CeramTec AG, Marktredwitz, Germany), which were installed at 0.2-m, 0.5-m and 0.9-m depths. Finally, the drainage flux was calculated as the net vertical flux at the sampling depth of soil solution $(0.6 \mathrm{~m})$.

$\mathrm{N}_{2} \mathrm{O}$ emissions were measured seven times in 2009 and five times in 2010 using closed chamber method. One polyvinyl chloride chamber base $\left(0.07 \mathrm{~m}^{2}\right.$ area, $0.35-0.4 \mathrm{~m}$ height of chamber base and cover) was installed permanently in each plot. For each measurement, the chamber base was covered with a polyethylene chamber hood fitted with a vent and a sampling port. Following chamber closure, gas samples were taken four times at 15-minute interval and stored into pre-evacuated 100-ml glass bottles fitted with teflon-coated stopcocks. $\mathrm{N}_{2} \mathrm{O}$ was analyzed using a gas chromatograph (GC 6000, Carlo Erba Instruments/Thermo Fisher Scientific, Milan, Italy) equipped with an electron capture detector and an autosampler system (Loftfield et al., 1997). Gas concentrations were calculated by comparing the sample peak integrals with the peak integrals of three standard gases (353, 1018 and 1604 ppb $\mathrm{N}_{2} \mathrm{O}$; Deuste Steiniger GmbH, Mühlhausen, Germany). $\mathrm{N}_{2} \mathrm{O}$ emissions were calculated by the linear increase of $\mathrm{N}_{2} \mathrm{O}$ concentration versus time for each chamber, corrected with the measured air temperature and pressure at the time of sampling.

\subsubsection{STATISTICAL ANALYSIS}

To test treatment differences of time-series parameters $\left(\mathrm{NO}_{3}{ }^{-}\right.$leaching, DON leaching and $\mathrm{N}_{2} \mathrm{O}$ emissions), we used linear mixed effects models (LME): treatments (fertilization, mowing frequency and sward composition) and row / column of the Latin rectangle design were considered fixed effects whereas sampling dates and spatial replications were included as random effects. The LME model included either 1) a variance function that allows different variances of the response variable for the fixed effects (Zuur et al., 2009), 2) a first-order temporal autoregressive process that assumes the correlation between measurements decreases with increasing time difference, or both if these improve the relative goodness of model fit based on the Akaike Information Criterion (AIC) (Crawley, 2007). Pairwise 
comparisons (T test with Holmes correction) were used as post-hoc tests. To test treatment differences of parameters measured one time (gross $\mathrm{N}$ transformation rates, microbial biomass, and $\mathrm{N}$ retention efficiency), we used two-way analysis of variance followed by Tukey's HSD post-hoc test. In all tests, if residual plots revealed non-normal distribution or non-homogeneity of variance we used either logarithmic or square root transformation (after adding a constant value if the dataset included negative values) and analyses were repeated. Non-significant effects of treatment interactions and of row and column were removed stepwise from the statistical models if this improved AIC (Crawley, 2007). Correlations between $\mathrm{N}$ retention efficiency and soil or plant parameters were assessed using Spearman's rank correlation. A significance level of $P=0.05$ was used throughout unless stated otherwise. All statistical analyses were performed using the R version 2.11.1 (R Development Core Team, 2009).

\subsection{RESULTS}

\subsubsection{GROSS N TRANSFORMATION RATES AND MICROBIAL BIOMASS}

Gross rates of $\mathrm{N}$ mineralization ranged from 71 to $1440 \mathrm{mg} \mathrm{N} \mathrm{m}^{-2} \mathrm{~d}^{-1}$ with an overall mean of $606( \pm 65 \mathrm{SE}) \mathrm{mg} \mathrm{N} \mathrm{m} \mathrm{m}^{-2} \mathrm{~d}^{-1}$. Neither fertilization nor sward composition affected gross $\mathrm{N}$ mineralization (Table 4.2). In contrast, gross nitrification rates were higher in the fertilized plots whereas sward composition showed no effect. $\mathrm{NH}_{4}{ }^{+}$immobilization rates varied between 143 and $2356 \mathrm{mg} \mathrm{N} \mathrm{m}^{-2} \mathrm{~d}^{-1}$ with an overall mean of $753( \pm 100 \mathrm{SE}) \mathrm{mg} \mathrm{N} \mathrm{m}^{-2}$ $\mathrm{d}^{-1}$ and were marginally lower in the fertilized than unfertilized plots (Table 4.2). Across treatments, gross $\mathrm{N}$ mineralization rates were positively correlated with $\mathrm{NH}_{4}{ }^{+}$immobilization rates $(P<0.001$, rho $=0.75, \mathrm{n}=23)$ and gross nitrification rates were negatively correlated with $\mathrm{NH}_{4}{ }^{+}$immobilization rates $(P=0.013$, rho $=-0.52, \mathrm{n}=22)$. Microbial $\mathrm{C}$ was not affected by any of the treatments, but fertilization resulted in marginally lower microbial N. A marginally significant interaction between fertilization and sward composition suggested that the decrease in microbial $\mathrm{N}$ caused by fertilization was pronounced in the dicot- and monocotenhanced swards, which also showed in their highest microbial C:N ratios (Table 4.2). 
Table 4.2 Gross rates of soil N cycling and microbial biomass (mean \pm SE) of a grassland in the Solling uplands, Germany with different sward compositions and management practices.

\begin{tabular}{|c|c|c|c|c|c|c|c|c|}
\hline Main factors & Treatments & $\mathrm{n}$ & $\begin{array}{c}\text { Gross } \mathrm{N} \\
\text { mineralization rate } \\
\left(\mathrm{mg} \mathrm{N} \mathrm{m}^{-2} \mathrm{~d}^{-1}\right)\end{array}$ & $\begin{array}{l}\text { Gross nitrification } \\
\text { rate } \\
\left(\mathrm{mg} \mathrm{N} \mathrm{m}^{-2} \mathrm{~d}^{-1}\right)\end{array}$ & $\begin{array}{c}\mathrm{NH}_{4}{ }^{+} \text {immobilization } \\
\text { rate } \\
\left(\mathrm{mg} \mathrm{N} \mathrm{m}^{-2} \mathrm{~d}^{-1}\right)\end{array}$ & $\begin{array}{l}\text { Microbial C } \\
\left(\mathrm{mg} \mathrm{C} \mathrm{m}^{-2}\right)\end{array}$ & $\begin{array}{l}\text { Microbial } \mathrm{N} \\
\left(\mathrm{mg} \mathrm{N} \mathrm{m}^{-2}\right)\end{array}$ & Microbial C:N \\
\hline \multirow[t]{4}{*}{ Sward composition } & & & $P=0.478$ & $P=0.367$ & $P=0.383$ & $P=0.970$ & $P=0.736$ & $P=0.348$ \\
\hline & control & 10 & $730( \pm 115) \mathrm{a}$ & $92( \pm 26) \mathrm{a}$ & $978( \pm 252) \mathrm{a}$ & $50295( \pm 5707) \mathrm{a}$ & $6870( \pm 999) \mathrm{a}$ & $7.53( \pm 0.29) \mathrm{a}$ \\
\hline & dicot-enhanced & 10 & $530( \pm 114) \mathrm{a}$ & $112( \pm 47)$ a & $665( \pm 133)$ a & $46428( \pm 4908)$ a & $5921( \pm 730)$ a & $8.03( \pm 0.21) \mathrm{a}$ \\
\hline & monocot-enh. & 10 & $570( \pm 113) \mathrm{a}$ & $123( \pm 80) \mathrm{a}$ & $640( \pm 119) \mathrm{a}$ & $48190( \pm 3454) \mathrm{a}$ & $6263( \pm 548) \mathrm{a}$ & $7.84( \pm 0.33) \mathrm{a}$ \\
\hline \multirow[t]{3}{*}{ Fertilization } & & & $P=0.513$ & $P=0.009$ & $P=0.070$ & $P=0.203$ & $P=0.088$ & $P=0.386$ \\
\hline & no & 15 & $654( \pm 93) a$ & $48( \pm 9) b$ & $891( \pm 133) a$ & $51819( \pm 2875) \mathrm{a}$ & $6797( \pm 375) \mathrm{a}$ & $7.65( \pm 0.18) \mathrm{a}$ \\
\hline & NPK & 15 & $554( \pm 94) a$ & $204( \pm 66) \mathrm{a}$ & $494( \pm 95) b$ & $44789( \pm 4441) \mathrm{a}$ & $5906( \pm 798) \mathrm{a}$ & $7.94( \pm 0.27) \mathrm{a}$ \\
\hline Sward composition $\mathrm{x}$ & & & $P=0.774$ & $P=0.504$ & $P=0.735$ & $P=0.103$ & $P=0.097$ & $P=0.093$ \\
\hline \multicolumn{9}{|l|}{ Fertilization } \\
\hline control & no & 5 & $824( \pm 170) \mathrm{a}$ & $77( \pm 25) b$ & $1178( \pm 311) \mathrm{a}$ & $47798( \pm 3717) \mathrm{a}$ & $6104( \pm 226) \mathrm{a}$ & $7.82( \pm 0.48) \mathrm{a}$ \\
\hline control & NPK & 5 & $612( \pm 151) \mathrm{a}$ & $112( \pm 55) \mathrm{a}$ & $478( \pm 125) b$ & $52791( \pm 11354)$ a & $7637( \pm 2030) \mathrm{a}$ & $7.24( \pm 0.34) \mathrm{a}$ \\
\hline dicot-enhanced & no & 5 & $584( \pm 168) \mathrm{a}$ & $49( \pm 8) b$ & $788( \pm 180) \mathrm{a}$ & $52465( \pm 6236) \mathrm{a}$ & $6732( \pm 861) \mathrm{a}$ & $7.85( \pm 0.20) \mathrm{a}$ \\
\hline dicot-enhanced & NPK & 5 & $477( \pm 167) \mathrm{a}$ & $190( \pm 88) a$ & $512( \pm 197) b$ & $40391( \pm 7128) a$ & $5109( \pm 1148) a$ & $8.20( \pm 0.38) \mathrm{a}$ \\
\hline monocot-enhanced & no & 5 & $554( \pm 146) \mathrm{a}$ & $24( \pm 7) b$ & $707( \pm 160) \mathrm{a}$ & $55194( \pm 5166)$ a & $7555( \pm 643) \mathrm{a}$ & $7.29( \pm 0.07) \mathrm{a}$ \\
\hline monocot-enhanced & NPK & 5 & $586( \pm 189) \mathrm{a}$ & $368( \pm 224) a$ & $473( \pm 50) b$ & $41185( \pm 1508) \mathrm{a}$ & $4972( \pm 314) \mathrm{a}$ & $8.40( \pm 0.56) \mathrm{a}$ \\
\hline
\end{tabular}

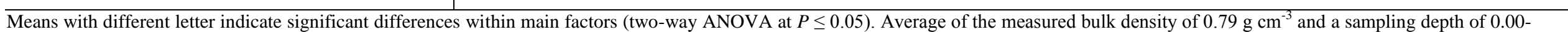
$0.05 \mathrm{~m}$ were used to convert rates on a dry mass basis to area-based rates. 


\subsubsection{WATER BALANCE AND N LOSSES}

During the experimental period, total annual precipitation was $1001 \mathrm{~mm}$ in 2009 and $1083 \mathrm{~mm}$ in 2010. Modelled annual evapotranspiration was $507 \mathrm{~mm}$ in 2009 and $484 \mathrm{~mm}$ in 2010. Modelled drainage flux was $441 \mathrm{~mm}$ in 2009 and $609 \mathrm{~mm}$ in 2010. At all three soil depths, measured matrix potential was correlated with modelled matrix potential (Spearman's correlation coefficients ranged from 0.58 to 0.75 with $P<0.02$, tested for each depth). In both years, modelled drainage flux was negligible in the summer months and strongly increased to values of more than $3 \mathrm{~mm} \mathrm{~d}^{-1}$ in autumn. Parallel to drainage flux, $\mathrm{NO}_{3}{ }^{-}$leaching losses were also negligible in the summer months (Figure $4.1 \mathrm{a}, \mathrm{b}, \mathrm{c}$ ). In fertilized plots, $\mathrm{NO}_{3}{ }^{-}$leaching strongly increased during autumn. The first year of treatment (2009) showed the peak of $\mathrm{NO}_{3}{ }^{-}$ leaching only during the spring of the following year while the second year of treatment (2010) showed the peaks of $\mathrm{NO}_{3}{ }^{-}$leaching immediately during the fall of the same year. In 2009, fertilization was the only factor that influenced $\mathrm{NO}_{3}{ }^{-}$leaching $(P=0.026$; unfertilized plots: $0.53( \pm 0.09 \mathrm{SE}) \mathrm{mg} \mathrm{NO}_{3}{ }^{-} \mathrm{N} \mathrm{m}^{-2} \mathrm{~d}^{-1}$; fertilized plots: $1.15( \pm 0.15 \mathrm{SE}) \mathrm{mg} \mathrm{NO}{ }^{-}-\mathrm{N} \mathrm{m}^{-2} \mathrm{~d}^{-}$ $\left.{ }^{1}\right)$. In 2010, fertilization ( $P=0.000$; unfertilized plots: $2.73( \pm 1.00 \mathrm{SE}) \mathrm{mg} \mathrm{NO}_{3}^{-}-\mathrm{N} \mathrm{m}^{-2} \mathrm{~d}^{-1}$; fertilized plots: $\left.17.18( \pm 2.95 \mathrm{SE}) \mathrm{mg} \mathrm{NO}_{3}{ }^{-}-\mathrm{N} \mathrm{m}^{-2} \mathrm{~d}^{-1}\right)$ and mowing frequency $(P=0.033$; cut once per year: $12.96( \pm 2.87 \mathrm{SE}) \mathrm{mg} \mathrm{NO}_{3}{ }^{-} \mathrm{N} \mathrm{m}^{-2} \mathrm{~d}^{-1}$; cut three times per year: $6.61( \pm 1.38$ SE) $\left.\mathrm{mg} \mathrm{NO}_{3}{ }^{-} \mathrm{N} \mathrm{m}^{-2} \mathrm{~d}^{-1}\right)$ influenced $\mathrm{NO}_{3}^{-}$leaching. An interaction $(P=0.011)$ between these factors showed that the increase in $\mathrm{NO}_{3}{ }^{-}$leaching losses caused by fertilization was only significant in plots cut once per year whereas plots cut three times per year were not affected. Sward composition did not affect $\mathrm{NO}_{3}{ }^{-}$leaching.

Leaching of DON ranged between 0 to $1.9 \mathrm{mg} \mathrm{N} \mathrm{m}^{-2} \mathrm{~d}^{-1}$ with an overall mean of 0.26 $( \pm 0.01 \mathrm{SE}) \mathrm{mg} \mathrm{N} \mathrm{m}^{-2} \mathrm{~d}^{-1}$ in 2009. None of the treatment factors influenced DON leaching (Figure $4.1 \mathrm{~d}, \mathrm{e}, \mathrm{f})$. In 2010, DON leaching increased to an overall mean of $0.6( \pm 0.10 \mathrm{SE})$ $\mathrm{mg} \mathrm{N} \mathrm{m} \mathrm{d}^{-2}$, ranging from 0 to $13.06 \mathrm{mg} \mathrm{N} \mathrm{m}^{-2} \mathrm{~d}^{-1}$. We detected interaction effect between fertilization and mowing frequency $(P=0.006)$ : fertilization increased DON leaching in plots cut once per year but not in plots cut three times per year. No effect of sward composition on DON leaching was detected. 


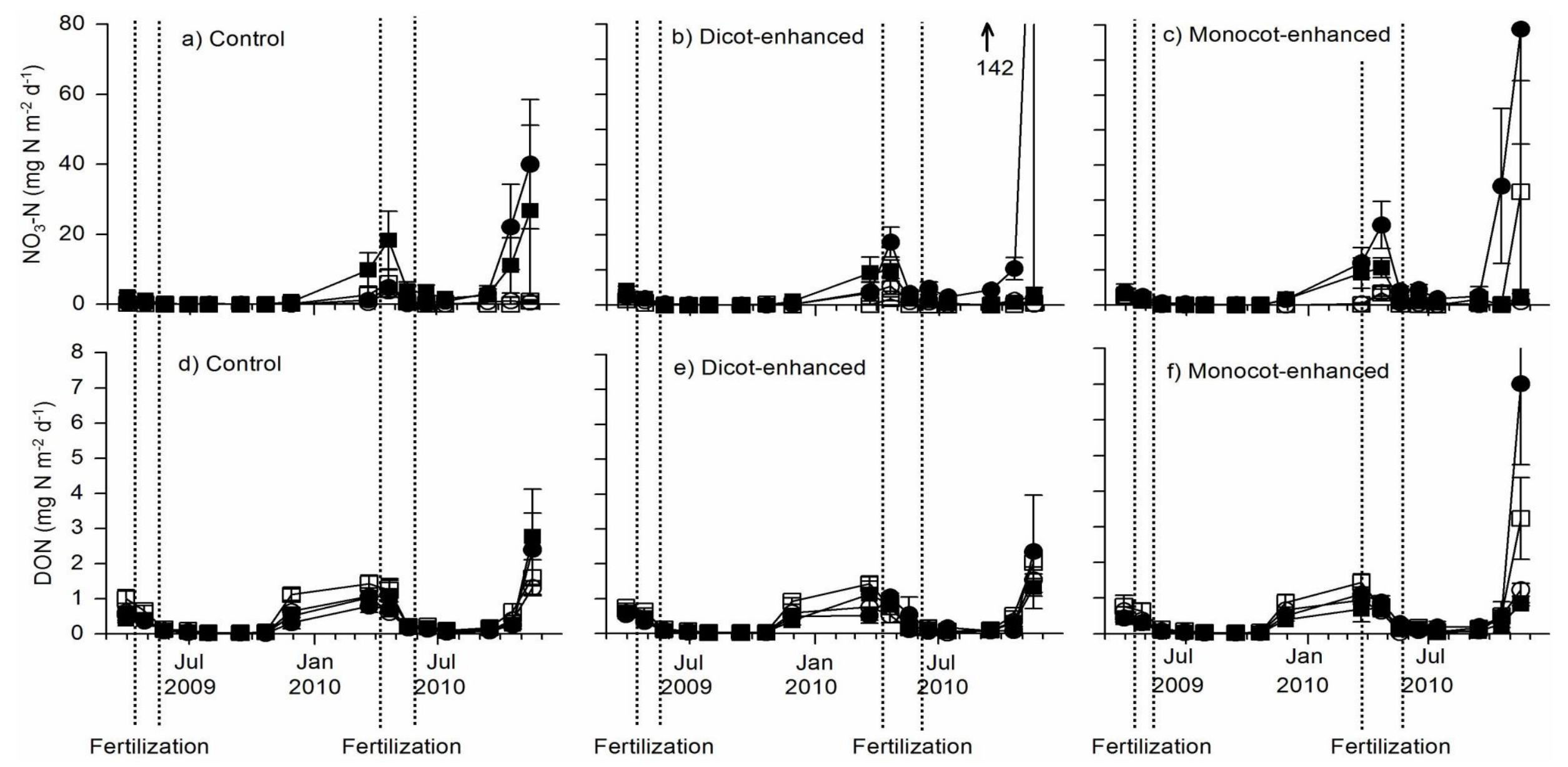

Figure 4.1 Nitrate $\left(\mathrm{NO}_{3}^{-}\right)$and dissolved organic nitrogen (DON) leaching losses $( \pm \mathrm{SE}, \mathrm{n}=6)$ at $0.5-0.6-\mathrm{m}$ depth from a grassland in the Solling uplands, Germany with different sward compositions and management practices: one mowing per year without fertilization $(\circ)$, one mowing per year with fertilization $(\bullet)$, three mowings per year

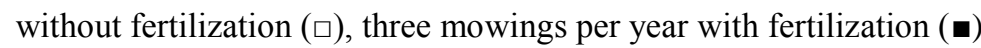


In 2009, fertilization $\left(P=0.000\right.$; unfertilized plots: $0.14( \pm 0.05 \mathrm{SE}) \mathrm{mg} \mathrm{N}_{2} \mathrm{O}-\mathrm{N} \mathrm{m}^{-2} \mathrm{~d}^{-}$ ; fertilized plots: $\left.0.50( \pm 0.22 \mathrm{SE}) \mathrm{mg} \mathrm{N}_{2} \mathrm{O}-\mathrm{N} \mathrm{m}^{-2} \mathrm{~d}^{-1}\right)$, mowing frequency $(P=0.031$; cut once per year: $0.41( \pm 0.22 \mathrm{SE}) \mathrm{mg} \mathrm{N}_{2} \mathrm{O}-\mathrm{N} \mathrm{m}^{-2} \mathrm{~d}^{-1}$; cut three times per year: $0.23( \pm 0.07 \mathrm{SE})$ mg $\left.\mathrm{N}_{2} \mathrm{O}-\mathrm{N} \mathrm{m}^{-2} \mathrm{~d}^{-1}\right)$ and their interaction $(P=0.009)$ influenced $\mathrm{N}_{2} \mathrm{O}$ emissions (Figure $4.2 \mathrm{a}$, b, c). Fertilized plots showed an increase in $\mathrm{N}_{2} \mathrm{O}$ fluxes, especially following the second fertilizer application in May. However, this increase was only significant for the plots cut once per year. Unfertilized plots only showed a marginal increase in $\mathrm{N}_{2} \mathrm{O}$ fluxes during the summer months. In 2010, fertilization ( $P=0.000$; unfertilized plots: $0.17( \pm 0.05 \mathrm{SE}) \mathrm{mg}$ $\mathrm{N}_{2} \mathrm{O}-\mathrm{N} \mathrm{m}^{-2} \mathrm{~d}^{-1}$; fertilized plots: $\left.0.73( \pm 0.24 \mathrm{SE}) \mathrm{mg} \mathrm{N}_{2} \mathrm{O}-\mathrm{N} \mathrm{m}^{-2} \mathrm{~d}^{-1}\right)$ also affected $\mathrm{N}_{2} \mathrm{O}$ emissions (Figure $4.2 \mathrm{~d}, \mathrm{e}, \mathrm{f}$ ). Again, the increase in $\mathrm{N}_{2} \mathrm{O}$ emissions occurred in the beginning of July after the second fertilization in June and the impact of fertilization tended to be stronger in plots cut once per year, but, unlike 2009, this treatment interaction was not significant $(P=0.108)$. In both years, $\mathrm{N}_{2} \mathrm{O}$ uptake predominantly occurred in unfertilized plots. There was no impact of sward composition on $\mathrm{N}_{2} \mathrm{O}$ emissions. 


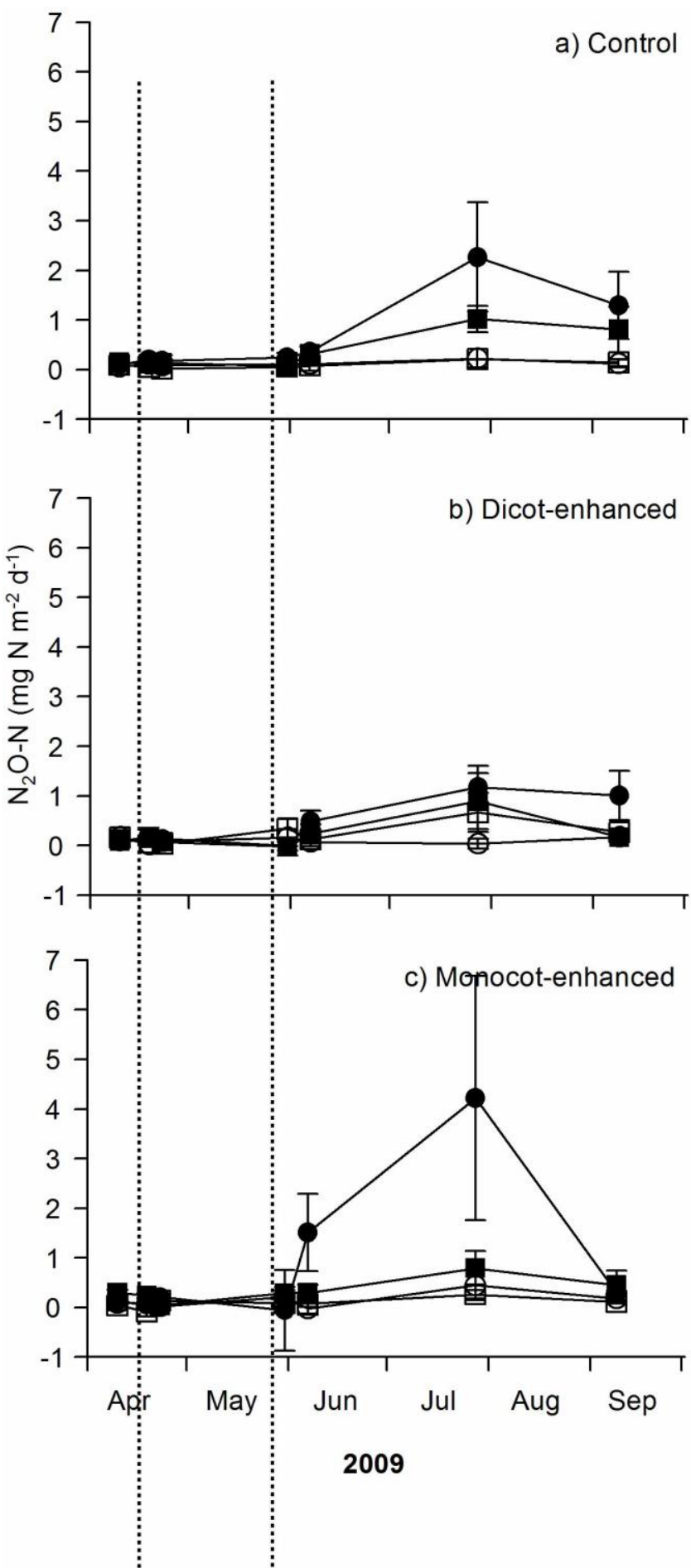

Fertilization

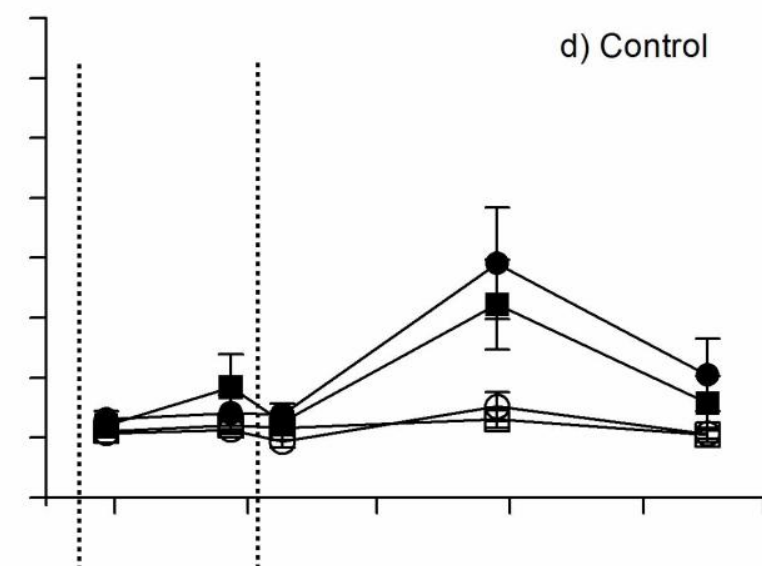

e) Dicot-enhanced

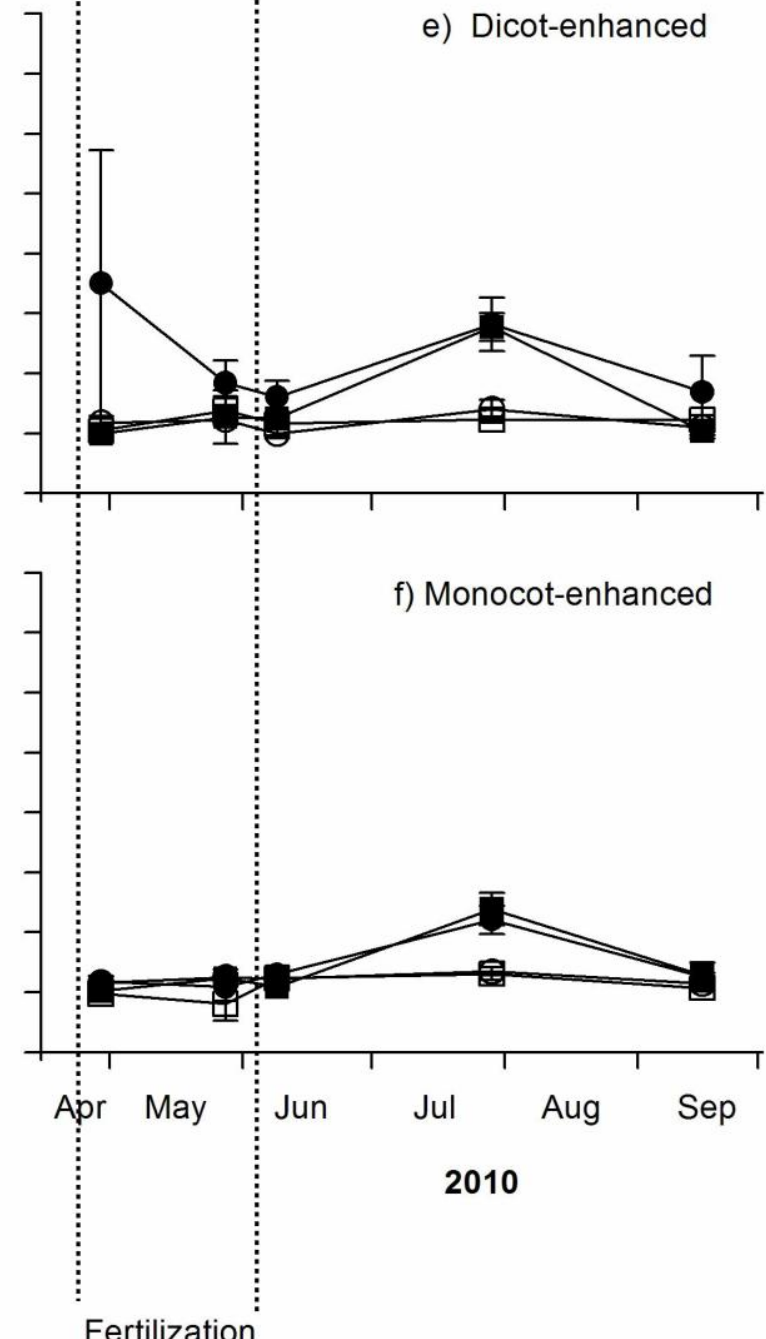

Fertilization

Figure 4.2 Nitrous oxide $\left(\mathrm{N}_{2} \mathrm{O}\right)$ emissions $( \pm \mathrm{SE}, \mathrm{n}=6)$ from a grassland in the Solling uplands, Germany with different sward compositions and management practices: one mowing per year without fertilization $(\circ)$, one mowing per year with fertilization $(\bullet)$, three mowings per year without fertilization $(\square)$, three mowings per year with fertilization (a). 


\subsubsection{N RETENTION EFFICIENCY}

We calculated $\mathrm{N}$ retention efficiency only for 2010 when gross rates of $\mathrm{N}$ mineralization was measured, and this ranged from 0.842 to 0.999 with an overall mean of 0.976 ( $\pm 0.02 \mathrm{SE})$. Fertilization decreased $\mathrm{N}$ retention efficiency and explained the variance more than the sward composition (Table 4.3). N retention efficiency was highest in the control sward followed by the dicot-enhanced and monocot-enhanced swards. Only the difference between control and monocot-enhanced swards was significant. Across all treatments, $\mathrm{N}$ retention efficiency was correlated with microbial $\mathrm{NH}_{4}{ }^{+}$immobilization, microbial $\mathrm{N}$ and $\mathrm{C}$, marginally correlated with plant $\mathrm{N}$ uptake, and not correlated with harvested plant biomass (Table 4.4). 
Table 4.3 N retention efficiency of a grassland in the Solling uplands, Germany with different sward compositions and fertilization.

\begin{tabular}{|c|c|c|c|c|c|c|}
\hline Main factors & Treatments & $\mathrm{n}$ & $\begin{array}{c}\mathrm{N} \text { retention efficiency } \\
{\left[1-\left(\mathrm{mg} \mathrm{N} \text { losses } \mathrm{m}^{-2} \mathrm{~d}^{-1} /\right.\right.} \\
\left.\left.\text { mg gross } \mathrm{N} \text { mineralization } \mathrm{m}^{-2} \mathrm{~d}^{-1}\right)\right]\end{array}$ & $\mathrm{SE}$ & $P$ & $\begin{array}{l}\text { Variance } \\
\text { explained } \\
(\%)\end{array}$ \\
\hline \multirow[t]{4}{*}{ Sward compo } & & & & & 0.046 & 16.69 \\
\hline & control & 12 & $0.991 \mathrm{a}$ & 0.005 & & \\
\hline & dicot-enhanced & 12 & $0.981 \mathrm{ab}$ & 0.005 & & \\
\hline & monocot-enhanced & 12 & $0.963 \mathrm{~b}$ & 0.016 & & \\
\hline \multirow[t]{3}{*}{ Fertilization } & & & & & 0.007 & 22.06 \\
\hline & no & 18 & $0.995 \mathrm{a}$ & 0.002 & & \\
\hline & NPK & 18 & $0.960 \mathrm{~b}$ & 0.011 & & \\
\hline
\end{tabular}

Means with different letter indicate significant differences among treatments within main factors (two-way ANOVA with Tukey's HSD at $P \leq 0.05$ ). 
Table 4.4 Spearman rank correlations between $\mathrm{N}$ retention efficiency and plant and soil-microbial parameters of a grassland site across different treatments of management practices in the Solling uplands, Germany.

\begin{tabular}{lcc}
\hline Parameter & Spearman's rho & $P$ \\
\hline Plant N uptake * & 0.338 & 0.074 \\
Harvested plant biomass * & -0.031 & 0.871 \\
Microbial $\mathrm{NH}_{4}^{+}$ & & \\
Immobilization $^{+}$ & 0.560 & 0.006 \\
Microbial biomass C & 0.364 & 0.053 \\
Microbial biomass N & 0.417 & 0.025
\end{tabular}

"Plant N uptake was reported by Keuter et al. (2013) and harvested biomass was reported by From et al. (2011). 


\subsection{DISCUSSION}

\subsubsection{GROSS N TRANSFORMATION RATES AND MICROBIAL BIOMASS}

Gross $\mathrm{N}$ mineralization and $\mathrm{NH}_{4}{ }^{+}$immobilization rates were larger than those reported for temperate grasslands in northeastern USA (Corre et al., 2002) and in the UK (Jamieson et al., 1999; Ledgard et al., 1998). Gross nitrification rates were in the same range as those reported for fertilized and unfertilized temperate grasslands in Belgium (Accoe et al., 2004) and Northern Ireland (Watson and Mills, 1998). The marginally lower $\mathrm{NH}_{4}{ }^{+}$immobilization and larger nitrification rates in the fertilized compared to the unfertilized plots demonstrated that fertilization decreased microbial retention of $\mathrm{NH}_{4}{ }^{+}$, possibly resulting to competitive advantage of the nitrifiers. This was also supported by the negative correlation between $\mathrm{NH}_{4}{ }^{+}$ immobilization rates and gross nitrification rates across treatments. A negative effect of $\mathrm{N}$ fertilization on microbial $\mathrm{N}$ immobilization in a grassland was also reported by Ledgard et al. (1998). Near to our grassland site, fertilized plots of beech forest (receiving high ambient $\mathrm{N}$ deposition of $\geq 25 \mathrm{~kg} \mathrm{~N} \mathrm{ha}^{-1} \mathrm{y}^{-1}$ and on top of this chronic $\mathrm{N}$ fertilization of $140 \mathrm{~kg} \mathrm{~N} \mathrm{ha}^{-1} \mathrm{y}^{-1}$ for 9 years) also showed reduced $\mathrm{NH}_{4}{ }^{+}$immobilization rates relative to gross $\mathrm{N}$ mineralization rates compared to the control beech plots that showed similar $\mathrm{NH}_{4}{ }^{+}$immobilization and gross $\mathrm{N}$ mineralization rates (Corre et al., 2003). The reduced $\mathrm{NH}_{4}{ }^{+}$immobilization in fertilized plots of beech forest as well as our grassland site was paralleled by marginal reduction of microbial $\mathrm{N}$, suggesting reduced $\mathrm{N}$ demand for build-up of microbial biomass. Other studies on chronic, high $\mathrm{N}$ fertilization consistently showed reduced microbial biomass (Compton et al., 2004; DeForest et al., 2004), which may be because addition of $\mathrm{N}$ would favored certain microbial community over the others. As to the effect of sward composition, the marginal reduction in microbial $\mathrm{N}$ and marginal increases in microbial $\mathrm{C}: \mathrm{N}$ ratios due to fertilization that was more distinct in the dicot- and monocot-enhanced swards rather than in the control swards suggest that the control sward plots were able to take the added $\mathrm{N}$ without changes in microbial biomass size and composition (e.g. no change in microbial C:N ratio). Such resilience of the control swards could be due to the adaptation feedback between soil microbial biomass and plant functional group composition, which may have developed from decades of extensive management practices in this site. Conversely, modifying the plant functional diversity of this grassland was unable to counteract the effect of $\mathrm{N}$ addition on depressing microbial $\mathrm{N}$ pool and changes in microbial composition. 


\subsubsection{N LOSSES}

Increased nitrification rates in fertilized plots had resulted to increased $\mathrm{N}$ losses compared to unfertilized plots. In 2009, the average rate of $\mathrm{NO}_{3}{ }^{-}$leaching was lower than those reported by other studies in fertilized temperate grasslands (e.g. Christian and Riche, 1998). The larger increase in $\mathrm{NO}_{3}{ }^{-}$leaching in 2010 than in 2009 in fertilized plots was mainly due to the larger increases in $\mathrm{NO}_{3}{ }^{-}$concentrations of the leachate rather than any change in magnitude of the drainage fluxes, which indicated the continuous nature of fertilization effect on leaching. While in the first year of treatment (2009) the grassland was still able to retain most of the soil available $\mathrm{N}$ (e.g. higher biomass production and plant $\mathrm{N}$ uptake in 2009 compared to 2010; Keuter et al., 2013), this has diminished in the second year (2010) of treatment. Baker and Johnson (1981) reported a similar pattern of increased $\mathrm{NO}_{3}{ }^{-}$ concentrations in drainage water after three years of fertilization to a cropland in central Iowa, USA. Also, $\mathrm{NO}_{3}{ }^{-}$concentrations in leachate of $>60 \mathrm{mg} \mathrm{NO}_{3}-\mathrm{N} \mathrm{L}^{-1}$, similar to our findings in 2010, have been reported for fertilized (120 kg N y${ }^{-1}$ ) Miscanthuus grassland in Great Britain (Christian and Riche, 1998). DON leaching rates from our study were an order of magnitude lower than $\mathrm{NO}_{3}{ }^{-}$leaching rates and were lower compared to values reported from several agricultural studies, which range from 0.3 to $127 \mathrm{~kg} \mathrm{DON} \mathrm{ha}^{-1} \mathrm{y}^{-1}$ (e.g. van Kessel et al., 2009). Our low DON leaching rates may be related to the relatively low abundance of legumes, exclusive use of mineral fertilizer, and exclusion of grazing (van Kessel et al., 2009), all suggesting low possible sources of DON. Our measured $\mathrm{N}_{2} \mathrm{O}$ fluxes were comparable to other studies conducted in temperate grasslands. Median emission rates of 0.1 $\mathrm{mg} \mathrm{N}_{2} \mathrm{O}-\mathrm{N} \mathrm{m}^{-2} \mathrm{~d}^{-1}$ (unfertilized) and $0.2 \mathrm{mg} \mathrm{N}_{2} \mathrm{O}-\mathrm{N} \mathrm{m}^{-2} \mathrm{~d}^{-1}$ (fertilized with $200 \mathrm{~kg} \mathrm{~N} \mathrm{ha}^{-1} \mathrm{y}^{-1}$ ) were reported for a grassland in Switzerland (Flechard et al., 2005), and mean emission rates of 0.1 - $1.2 \mathrm{mg} \mathrm{N}_{2} \mathrm{O}-\mathrm{N} \mathrm{m}^{-2} \mathrm{~d}^{-1}$ were reported for a fertilized $\left(300 \mathrm{~kg} \mathrm{~N} \mathrm{ha}^{-1} \mathrm{y}^{-1}\right)$ grassland in Scotland (Jones et al., 2005).

The observed high $\mathrm{N}$ losses following fertilizer application, independent of the pathway $\left(\mathrm{NO}_{3}^{-}\right.$leaching, DON leaching and $\mathrm{N}_{2} \mathrm{O}$ emissions), is in line with our first hypothesis. Similar findings have been reported by studies on $\mathrm{NO}_{3}{ }^{-}$leaching (e.g. Christian and Riche, 1998), DON leaching (Dijkstra et al., 2007; Fang et al., 2009) and $\mathrm{N}_{2} \mathrm{O}$ fluxes (e.g. Jones et al., 2005). Our finding that increasing mowing frequency can decrease leaching of $\mathrm{NO}_{3}{ }^{-}$and DON and reduce $\mathrm{N}_{2} \mathrm{O}$ emissions from fertilized plots is at least partly in line with our second hypothesis that mowing reduces $\mathrm{N}$ losses. A decrease of $\mathrm{N}_{2} \mathrm{O}$ emissions with increasing mowing frequency was also reported for a 50-year established non-grazed 
grassland in Germany, and was interpreted as a result of a higher plant $\mathrm{N}$ uptake and thus lower nitrification and denitrification rates (Kammann et al., 1998). In the same site as our present study, we observed increases in plant $\mathrm{N}$ response efficiency (i.e. plant biomass produced per unit of plant-available $\mathrm{N}$ ) and plant $\mathrm{N}$ uptake efficiency (i.e. the proportion of plant-available $\mathrm{N}$ that is taken up by plants) with increasing mowing frequency (Keuter et al., 2013), which may be caused by overcompensatory regrowth following mowing (Guitian and Bardgett, 2000). Furthermore, microbial immobilization of $\mathrm{N}$ may also contribute to the influence of mowing since defoliation of plants increases rhizodeposition (Holland et al., 1996). An increased soil microbial biomass as a result of defoliation by cutting of grasses was reported by Guitian and Bardgett (2000). Thus, more frequent mowing may stimulate C input from plants to the soil which, in turn, may stimulate microbial $\mathrm{N}$ immobilization.

We observed no effect of sward compositions on $\mathrm{NO}_{3}{ }^{-}$and DON leaching and on $\mathrm{N}_{2} \mathrm{O}$ fluxes, which appears to be in contrast with some other studies. Decreasing soil extractable N caused by increasing plant species or functional group diversity has been reported (e.g. Tilman et al., 1996). On the other hand, plant species diversity effects on $\mathrm{NO}_{3}{ }^{-}$and $\mathrm{DON}$ leaching are not consistent. Hooper and Vitousek (1998) did not observe plant diversity effects on $\mathrm{NO}_{3}{ }^{-}$leaching in artificial grassland plots in California whereas Scherer-Lorenzen et al. (2003) observed a decrease in annual $\mathrm{NO}_{3}{ }^{-}$leaching losses with increasing plant functional group richness in an artificially established grassland in Germany. This effect however was only significant for communities containing legumes and hence may have been an effect of reduction in legume abundance rather than an effect of species richness per se (Scherer-Lorenzen et al., 2003). In contrast, significant decreases in mineral $\mathrm{N}$ and increases in DON leaching rates with increasing grass species diversity were reported for planted grassland plots in Minnesota, USA (Dijkstra et al., 2007). This was explained by a higher productivity and consequently higher organic $\mathrm{N}$ pools, higher microbial activity and higher DON production at higher levels of species richness. The study of Dijkstra et al. (2007) had strongly contrasting levels of species richness (1 versus 16 species) whereas the number of species in our site was at the high level (12-18 species) with only small differences among sward compositions. A review has shown that diversity effects are most pronounced in the range of one to five species (Wrage et al., 2011). This may be the reason why we were not able to detect plant diversity effects in our study. Also, in our other study (conducted in a 20year established, grazed grassland in Germany) $\mathrm{N}_{2} \mathrm{O}$ and $\mathrm{NO}$ fluxes were not affected by plant diversity (Hoeft et al., 2012). 


\subsubsection{N RETENTION EFFICIENCY}

The reduced $\mathrm{N}$ retention efficiency in the fertilized compared to unfertilized plots supported our hypothesis. This fertilization effect was caused by increased $\mathrm{N}$ losses rather than changes in gross $\mathrm{N}$ mineralization rates as the latter were not affected by fertilization. The increased $\mathrm{N}$ losses from fertilized plots were the result of increased gross nitrification rates which, in turn, were due to marginal decreased in $\mathrm{NH}_{4}{ }^{+}$immobilization rates. In the same study site for the same study years, we also observed that fertilized plots had lower plant $\mathrm{N}$ response efficiency and plant $\mathrm{N}$ uptake efficiency than unfertilized plots (Keuter et al., 2013). Thus, decrease in retention both through microbial immobilization and plant uptake caused decrease in $\mathrm{N}$ retention efficiency under fertilization.

Apart from fertilization, sward composition also affected $\mathrm{N}$ retention efficiency. The control sward had the highest $\mathrm{N}$ retention efficiency, which was in contrast to our hypothesis. In our earlier study, we also found higher $\mathrm{N}$ response efficiency and marginally higher $\mathrm{N}$ uptake efficiency for the control sward compared to the monocot- or dicot-enhanced swards (Keuter et al., 2013). The control sward has adapted to local soil and environmental conditions over decades of extensive management practices, such that this sward has probably developed towards a composition that is most efficient in retaining soil available $\mathrm{N}$. Correlations of $\mathrm{N}$ retention efficiency with $\mathrm{NH}_{4}{ }^{+}$immobilization and microbial biomass and only marginal correlation with plant $\mathrm{N}$ uptake (Table 4.4) corroborated that microbial assimilation may play a more important role than plant uptake on the efficiency with which $\mathrm{N}$ is retained in the soil-plant system. This supports the studies of Hooper and Vitousek (1997, 1998) who showed that microbial $\mathrm{N}$ immobilization may be a more important pathway for $\mathrm{N}$ retention than plant $\mathrm{N}$ uptake, and that indirect plant effects through microbial immobilization may equal or even exceed direct plant uptake effects on nutrient retention. 


\subsection{CONCLUSIONS}

Fertilizer application was the dominant factor influencing $\mathrm{N}$ losses and $\mathrm{N}$ retention efficiency, of which the latter was strongly influenced by microbial $\mathrm{NH}_{4}{ }^{+}$immobilization. Our results also show that intensive mowing can partly reduce the high $\mathrm{N}$ losses following $\mathrm{N}$ fertilization. We found indications that control swards that have developed under decades of extensive grassland management had the highest efficiency in retaining $\mathrm{N}$. This high $\mathrm{N}$ retention efficiency was caused by high plant $\mathrm{N}$ response efficiency and $\mathrm{N}$ uptake efficiency (Keuter et al., 2013) as well as high microbial $\mathrm{NH}_{4}{ }^{+}$immobilization in the soil. $\mathrm{N}$ retention efficiency responded to both sward compositions and fertilization whereas $\mathrm{N}$ losses were only sensitive largely to fertilization, signifying that $\mathrm{N}$ retention efficiency was a more sensitive index than just $\mathrm{N}$ losses when evaluating environmental sustainability of grasslands. Furthermore, our study underlines the importance of microbial immobilization for the retention of $\mathrm{N}$. In contrast to other more commonly used indices for plant response (e.g. $\mathrm{N}$ response efficiency and $\mathrm{N}$ uptake efficiency); $\mathrm{N}$ retention efficiency reflected the importance of microbial immobilization as a pathway for $\mathrm{N}$ retention in the plant-soil system. 


\section{CHAPTER}

5

\section{SYNTHESIS}




\subsection{SYNTHESIS AND DISCUSSION OF THE MAJOR FINDINGS}

In the synthesis, I aim to integrate the major findings obtained from our two studies (BIOMIX \& GRASSMAN) and to draw more general conclusions about the importance of management and plant diversity for the functioning of grassland ecosystems. We analyzed a grazed grassland (BIOMIX) and a cut grassland (GRASSMAN) with a particular focus on $\mathrm{N}$ losses $\left(\mathrm{N}_{2} \mathrm{O}\right.$ and $\mathrm{NO}$ emissions, $\mathrm{N}$ leaching) and $\mathrm{N}$ dynamics (net and gross mineralization and nitrification); and calculated $\mathrm{N}$ response efficiency and $\mathrm{N}$ retention efficiency as a measure for ecosystem functioning. In BIOMIX, the grassland management differed in the type of livestock (cattle and sheep). In GRASSMAN, the management differed in fertilization $\left(180-30-100 \mathrm{~kg} \mathrm{NPK} \mathrm{ha}{ }^{-1} \mathrm{yr}^{-1}\right.$ and no fertilization) or in mowing frequency (once and thrice per year). In both study sites, sward botanical compositions were manipulated by specific herbicide application, i.e. by reducing the abundance of certain plant functional groups.

\subsubsection{THE EFFECTS OF LIVESTOCK GRAZING ON ECOSYSTEM FUNCTIONING}

In BIOMIX, the type of grazer (cattle and sheep) had an effect on gaseous $\mathrm{N}$ losses on pastures. The hypothesized larger $\mathrm{N}$ oxide losses on sheep-grazed paddocks compared with those grazed by cattle could be confirmed for cumulative NO emissions in grass swards. N losses are linked with the $\mathrm{N}$ supply in the soil, which on pastures mainly depend on the $\mathrm{N}$ applied with excreta. Our hypothesis was based on the amount and frequency of urinations and defecations and the number of cattle and sheep per paddock. The measured gaseous $\mathrm{N}$ losses were dominated by the occasional measurement of urine and dung hotspots, which we attributed to an apparently more even spread of sheep excreta compared to cattle excreta ( $1.16 \%$ of the paddock area per day for sheep grazing, $0.81 \%$ for cattle grazing). However, per excreta patch, larger $\mathrm{N}$ losses were found for cattle than for sheep excreta due to larger $\mathrm{N}$ supply in the soil. 


\subsubsection{THE EFFECTS OF MANAGEMENT INTENSITY (FERTILIZATION AND MOWING) ON ECOSYSTEM FUNCTIONING}

A pattern similar to the effect of livestock grazing in BIOMIX was found in GRASSMAN: fertilization was the most important factor influencing $\mathrm{N}$ losses with hypothesized larger $\mathrm{N}$ losses on the fertilized plots. The determined $\mathrm{N}$ losses were relatively small compared to reported $\mathrm{N}_{2} \mathrm{O}$ emissions of Flechard et al. (2005) or $\mathrm{NO}_{3}{ }^{-}$leaching losses of Christian and Riche (1998) on ungrazed and fertilized grassland sites. We hypothesized increasing $\mathrm{N}$ losses with decreasing mowing frequency, as our findings showed a decrease in $\mathrm{N}_{2} \mathrm{O}$ emissions and $\mathrm{NO}_{3}^{-}$leaching losses on the intensively mown and on the fertilized plots. Our results corresponded to the findings of Kammann et al. (1998) who reported a decrease of $\mathrm{N}_{2} \mathrm{O}$ emissions with increasing mowing frequency on a German grassland site. Our findings indicated that plots cut thrice per year can counteract the negative effects of $\mathrm{N}$ fertilization regarding $\mathrm{N}$ losses. Especially the combination of fertilization and only one cut per year caused larger $\mathrm{N}$ losses via $\mathrm{N}_{2} \mathrm{O}$ emissions and $\mathrm{NO}_{3}{ }^{-}$leaching.

In GRASSMAN, fertilization largely influenced $\mathrm{N}$ response efficiency. The hypothesized smaller $\mathrm{N}$ response efficiency of the fertilized compared to unfertilized plots was caused by decreases in both $\mathrm{N}$ uptake efficiency and $\mathrm{N}$ use efficiency. As we assumed, mowing frequency also influenced $\mathrm{N}$ response efficiency via increasing $\mathrm{N}$ response efficiency in plots cut thrice per year. We attributed that to increasing $\mathrm{N}$ uptake efficiency, because $\mathrm{N}$ use efficiency was either showing the opposite trend or was not affected by mowing at all. The increased $\mathrm{N}$ uptake efficiency in plots cut thrice per year was paralleled by increased biomass yield and $\mathrm{N}$ concentration in biomass. $\mathrm{N}$ retention efficiency was also influenced by fertilization. We hypothesized smaller efficiencies in fertilized treatments compared to unfertilized treatments. The effect of fertilization was due to larger $\mathrm{N}$ losses rather than gross $\mathrm{N}$ mineralization rates which were not affected by the $\mathrm{N}$ surplus. Under fertilization, the decrease in $\mathrm{N}$ retention efficiency was caused through microbial $\mathrm{NH}_{4}{ }^{+}$immobilization. $\mathrm{N}$ retention efficiency was not calculated for the plots differing in mowing frequency. That was due to the fact that mowing frequency had no effect on net rates of mineralization and nitrification in 2009. Based on these results, we decided to sample gross rates of mineralization and nitrification only on plots cut once per year in 2010. 


\subsubsection{THE EFFECT OF SWARD COMPOSITION ON ECOSYSTEM FUNCTIONING}

In BIOMIX, we evaluated if sward composition has an effect on $\mathrm{N}_{2} \mathrm{O}$ and $\mathrm{NO}$ emissions in grazed grassland. Our findings for $\mathrm{N}$ oxide emissions were not consistent with our hypothesis of smaller emissions in more diverse plots, but were supported by the study of Seither et al. (2012) who also found no differences in $\mathrm{N}$ yield of different sward compositions in the same experiment. Combining the data from our two experiments (main and controlled application experiment) within the BIOMIX study, we can conclude that sward composition was less important compared to the effect of grazers on $\mathrm{N}$ oxide emissions. In GRASSMAN, neither $\mathrm{N}$ losses $\left(\mathrm{N}_{2} \mathrm{O}\right.$ emissions and $\mathrm{NO}_{3}{ }^{-}$leaching) nor $\mathrm{N}$ turnover (net and gross mineralization) was significantly affected by sward composition. This may imply that regardless of the plant functional composition in this grassland, $\mathrm{N}$ supply through mineralization as well as $\mathrm{N}$ use by the vegetation will be similar.

In GRASSMAN, sward composition influenced $\mathrm{N}$ response efficiency. The trends of $\mathrm{N}$ response efficiency and $\mathrm{N}$ uptake efficiency were similar whereas $\mathrm{N}$ use efficiency exhibited either opposite patterns or was not affected by sward composition. This emphasized that $\mathrm{N}$ uptake efficiency influenced $\mathrm{N}$ response efficiency more than $\mathrm{N}$ use efficiency. We assumed that $\mathrm{N}$ response efficiency decreases in the order dicot-enhanced swards $\geq$ control swards > monocot-enhanced swards, but found larger efficiencies in control compared to dicot- and monocot-enhanced swards. $\mathrm{N}$ retention efficiency was affected by sward composition. Contrary to our hypothesis, again untreated control swards were most efficient in $\mathrm{N}$ retention efficiency. We attributed the efficient $\mathrm{N}$ response and $\mathrm{N}$ retention to the ratio of $\sim 30 \%$ dicots and $\sim 70 \%$ monocots found in the control swards. This ratio developed in response to $\mathrm{N}$ limited conditions and previous management practices. In equilibrium with these conditions, this plant community would be expected to result in efficient $\mathrm{N}$ response and $\mathrm{N}$ retention. Both, an artificial increase in the proportion of dicots as well as an increase in the proportion of monocots resulted in smaller efficiencies, even if that leads to a more balanced proportion. 


\subsection{CONCLUDING RESULTS}

The indices of $\mathrm{N}$ response and $\mathrm{N}$ retention efficiency might be suitable indices and useful as measures for ecosystem functioning in temperate managed grassland. First, we considered biomass yield per unit of plant available $\mathrm{N}$ and second, we measured $\mathrm{N}$ losses per unit of soil available $\mathrm{N}$ retained in an ecosystem and did not focus on $\mathrm{N}$ losses exclusively. At the ecosystem level, these indices can be beneficial for the assessment of grassland with regard to sustainable land-use. Optimize $\mathrm{N}$ response and $\mathrm{N}$ retention may not be a target of most farmers, but they are appropriate tools to evaluate the consequenses of grassland management practices, which farmers may employ to maximize profit, on environmental quality. Our results showed that the management of grassland is the most important factor determining ecosystem functioning. Fertilization, mowing frequency and livestock grazing largely influenced $\mathrm{N}$ response efficiency, $\mathrm{N}$ retention efficiency and $\mathrm{N}$ losses. Sward species composition was still a factor influencing determining ecosystem functioning but to a minor importance in this context. These trends were also found in the same experiment by Rose (2011b) for the effect of land-use intensification and biodiversity on grassland biomass, water use and plant functional traits. Grassland management determined structure, productivity and ecosystem processes while species richness was less important.

\subsection{IMPLICATIONS AND SUGGESTIONS FOR FURTHER RESEARCH}

Combining all findings, we could speculate if plant diversity is important in the context of grassland management. If we consider only $\mathrm{N}$ losses, the management (grazing, fertilization or mowing frequency) of the grazed and the mown grasslands have a major impact, while sward composition was insignificant. Calculating the efficiencies of $\mathrm{N}$ response and $\mathrm{N}$ retention in GRASSMAN, sward composition became a significant factor. Consequently, it is important to consider not only $\mathrm{N}$ losses, but also evaluating available $\mathrm{N}$ in the soil (gross $\mathrm{N}$ mineralization and nitrification) and available $\mathrm{N}$ for the plant (net $\mathrm{N}$ mineralization and nitrification) and thus, calculating the efficiencies of $\mathrm{N}$ response and $\mathrm{N}$ retention. But the use of these indices on ecosystem level should be tested in future studies. 
Biodiversity studies were conducted in artificial grassland, e.g. Jena Experiment, Biodepth or Cedar Creek (Marquard et al., 2009; Spehn et al., 2005; Tilman et al., 1996) or as observational studies in permanent grassland (e.g. Kahmen et al., 2005). Our grassland studies (BIOMIX \& GRASSMAN) combined the advantages of artificial and observational studies e.g. real world, all ecosystem processes, controlled experiment, interactions can be tested. Starting with natural vegetation that was manipulated by removing certain species or functional groups, it can be tested for a set of defined environmental conditions (Diaz et al., 2003). In our studies, we used the approach of plant species removal by herbicides. In our pasture experiment (BIOMIX), the herbicide treatment on forbs lasted for three years. There already was a large invasion of species from diverse into grass swards. Grassland removal experiments treated by herbicides like our studies are appropriate for short-term experiments. After this time, another herbicide treatment should be carried out and that may have an impact on the $\mathrm{N}$ cycling again. Further studies are required due to sensitivity of plant functional groups to different herbicides. Finally, we suggest that it might be more advantageous to reduce the $\mathrm{N}$ input through excreta or mineral $\mathrm{N}$ fertilizer than to increase plant diversity in order to reduce $\mathrm{N}$ losses from grassland ecosystems. 


\section{REFERENCES}

Aber, J., W. McDowell, K. Nadelhoffer, A. Magill, G. Berntson, M. Kamakea, S. McNulty, W. Currie, L. Rustad, and I. Fernandez. 1998. Nitrogen saturation in temperate forest ecosystems. Bioscience 48:921-934.

Accoe, F., P. Boeckx, J. Buschaert, G. Hofman, and O. van Cleemput. 2004. Gross N transformation and net $\mathrm{N}$ mineralization rates related to the $\mathrm{C}$ and $\mathrm{N}$ contents of soil organic matter fractions in grassland soils of different age. Soil Biology \& Biochemistry 36:2075-2087.

Aerts, R .1990. Nutrient use efficiency in evergreen and deciduous species from heathlands. Oecologia 84:391-397.

Baker, J.L., and H.P. Johnson. 1981. Nitrate-nitrogen in tile drainage as affected by fertilization. Journal of Environmental Quality 10:519-522.

Blake, G.R., Hartge K. H. 1986. Bulk density, p. 363-375, In A. Klute, ed. Methods of soil analysis, part 1. Physical and mineralogical methods. Soil Science Society of America, Madison, Wisconsin, USA.

Bliese, P.D., and R.E. Ployhart. 2002. Growth modeling using random coefficient models: Model building, testing, and illustrations. Organizational Research Methods 5:362387.

Bolan, N.S., S. Saggar, J.F. Luo, R. Bhandral, and J. Singh. 2004. Gaseous emissions of nitrogen from grazed pastures: Processes, measurements and modelling, environmental implications, and mitigation, p. 37-120 Advances in Agronomy, Vol 84, Elsevier Academic Press Inc, San Diego.

Bridgham, S.D., J. Pastor, C.A. Mc Claugherty, and C.J. Richardson. 1995. Nutrient-use efficiency - a litterfall index, a model, and a test along a nutrient-availability gradient in North-Carolina peatlands. American Naturalist 145:1-21.

Bristow, A.W., J.C. Ryden, and D.C. Whitehead. 1987. The fate at several time intervals of $15 \mathrm{~N}$-labelled ammonium nitrate applied to an established grass sward. Journal of Soil Science 38:245-254.

Brookes, P.C., A. Landman, G. Pruden, and D.S. Jenkinson. 1985. Chloroform fumigation and the release of soil nitrogen: A rapid direct extraction method to measure microbial biomass nitrogen in soil. Soil Biology \& Biochemistry 17:837-842.

Caliman, A., A.F. Pires, F.A. Esteves, R.L. Bozelli, and V.F. Farjalla. 2010. The prominence of and biases in biodiversity and ecosystem functioning research. Biodiversity and Conservation 19:651-664.

Carter, M.S. 2007. Contribution of nitrification and denitrification to $\mathrm{N}_{2} \mathrm{O}$ emissions from urine patches. Soil Biology \& Biochemistry 39:2091-2102.

Christian, D.G., and A.B. Riche. 1998. Nitrate leaching losses under Miscanthuus grass planted on a silty clay loam soil. Soil Use and Management 14:131-135.

Clapp, R.B., and G.M. Hornberger. 1978. Empirical Equations for Some Soil HydraulicProperties. Water Resources Research 14:601-604.

Compton, J.E., L.S. Watrud, L.A. Porteous, and S. DeGrood. 2004. Response of soil microbial biomass and community composition to chronic nitrogen additions at Harvard forest. Forest Ecology and Management 196:143-458.

Corre, M.D., R.R. Schnabel, and W.L. Stout. 2002. Spatial and seasonal variation of gross nitrogen transformations and microbial biomass in a Northeastern US grassland. Soil Biology \& Biochemistry 34:445-457. 
Corre, M.D., F.O. Beese, and R. Brumme. 2003. Soil nitrogen cycle in high nitrogen deposition forest: changes under nitrogen saturation and liming. Ecological Applications 13:287-298.

Corre, M.D., and N.P. Lamersdorf. 2004. Reversal of nitrogen saturation after long-term deposition reduction: Impact on soil nitrogen cycling. Ecology 85:3090-3104.

Crawley, M.J. 2007. The R book John Wiley \& Sons Ltd, Chinchester, West Sussex.

Crutzen, P.J. 1979. Role of $\mathrm{NO}$ and $\mathrm{NO}_{2}$ in the chemistry of the troposphere and stratosphere. Annual Review of Earth and Planetary Sciences 7:443-472.

Davidson, E.A. 2009. The contribution of manure and fertilizer nitrogen to atmospheric nitrous oxide since 1860. Nature Geoscience 2:659-662.

Davidson, E.A., S.C. Hart, C.A. Shanks, and M.K. Firestone. 1991. Measuring gross nitrogen mineralization, immobilization, and nitrification by ${ }^{15} \mathrm{~N}$ isotopic pool dilution in intact soil cores. Journal of Soil Science 42:335-349.

Dawson, L.A., S.J. Grayston, and E. Paterson. 2000. Effects of grazing on the roots and rhizosphere of grasses, p. 61-84, In G. Lemaire, et al., eds. Grassland ecophysiology and grazing ecology. CABI Publishing, Wallingfort.

DeForest, J.L., D.R. Zak, K.S. Pregitzer, and A.J. Burton. 2004. Atmospheric nitrate deposition, microbial community composition, and enzyme activity in northern hardwood forests. Soil Science Society of America 68:132-138.

Di, H.J., and K.C. Cameron. 2002. Nitrate leaching in temperate agroecosystems: sources, factors and mitigating strategies. Nutrient Cycling in Agroecosystems 64:237-256.

Diaz, S., A.J. Symstad, F.S. Chapin, D.A. Wardle, and L.F. Huenneke. 2003. Functional diversity revealed by removal experiments. Trends in Ecology \& Evolution 18:140146.

Dijkstra, F.A., J.B. West, S.E. Hobbie, P.B. Reich, and J. Trost. 2007. Plant diversity, $\mathrm{CO}_{2}$, and $\mathrm{N}$ influence inorganic and organic $\mathrm{N}$ leaching in grasslands. Ecology 88:490-500.

Dobermann, A. 2005. Nitrogen use efficiency - state of the art IFA International Workshop on Enhanced-Efficiency Fertilizers, Frankfurt, Germany.

Ellenberg, H., and C. Leuschner. 2010. Vegetation Mitteleuropas mit den Alpen. 6 ed. Verlag Eugen Ulmer, Stuttgart.

EUROSTAT. 2001. Extensivzonen machen mindestens 42\% der landwirtschaftlichen Flächen aus. Landwirtschaft, Forstwirtschaft und Fischerei.

Ewel, J.J., M.J. Mazzarino, and C.W. Berish. 1991. Tropical Soil Fertility Changes under Monocultures and Successional Communities of Different Structure. Ecological Applications 1:289-302.

Fang, Y., W. Zhu, P. Gundersen, J. Mo, G. Zhou, and M. Yoh. 2009. Large loss of dissolved organic nitrogen from nitrogen-saturated forests in subtropical China. Ecosystems 12:33-45.

Federer, C.A., C. Vorosmarty, and B. Fekete. 2003. Sensitivity of annual evaporation to soil and root properties in two models of contrasting complexity. Journal of Hydrometeorology 4:1276-1290.

Ferraro, D.O., and M. Oesterheld. 2002. Effect of defoliation on grass growth. A quantitative review. Oikos 98:125-133.

Firestone, M.K., and E.A. Davidson. 1989. Microbiological basis of $\mathrm{NO}$ and $\mathrm{N}_{2} \mathrm{O}$ production and consumption in soil., p. 7-21, In M. O. Andraea and D. S. Schimel, eds. Exchange of trace gases between terrestrial ecosystems and the atmosphere. John Wiley and Sons Chichester, UK.

Flechard, C.R., A. Neftel, M. Jocher, C. Ammann, and J. Fuhrer. 2005. Bi-directional soil/atmosphere $\mathrm{N}_{2} \mathrm{O}$ exchange over two mown grassland systems with contrasting management practices. Global Change Biology 11:2114-2127. 
Flessa, H., P. Dorsch, F. Beese, H. Konig, and A.F. Bouwman. 1996. Influence of cattle wastes on nitrous oxide and methane fluxes in pasture land. Journal of Environmental Quality 25:1366-1370.

Flombaum, P., and O.E. Sala. 2008. Higher effect of plant species diversity on productivity in natural than artificial ecosystems. Proceedings of the National Academy of Sciences of the United States of America 105:6087-6090.

From, T., U.K. Petersen, and J. Isselstein. 2011. Productivity and forage quality of a phytodiverse semi-natural grassland under various management regimes [Online] http://precedings.nature.com/documents/6622/version/1.

Fuller, R.M. 1987. The changing extent and conservation interest of lowland grasslands in England and Wales - a review of grassland surveys 1930-84. Biological Conservation 40:281-300.

Galloway, J.N., A.R. Townsend, J.W. Erisman, M. Bekunda, Z.C. Cai, J.R. Freney, L.A. Martinelli, S.P. Seitzinger, and M.A. Sutton. 2008. Transformation of the nitrogen cycle: Recent trends, questions, and potential solutions. Science 320:889-892.

Green, B.H. 1990. Agricultural Intensification and the Loss of Habitat, Species and Amenity in British Grasslands - a Review of Historical Change and Assessment of FutureProspects. Grass and Forage Science 45:365-372.

Gruber, N., and J.N. Galloway. 2008. An Earth-system perspective of the global nitrogen cycle. Nature 451:293-296.

Guitian, R., and R.D. Bardgett. 2000. Plant and soil microbial responses to defoliation in temperate semi-natural grassland. Plant and Soil 220:271-277.

Hack-ten Broeke, M.J.D., W.J.M. De Groot, and J.P. Dijkstra. 1996. Impact of excreted nitrogen by grazing cattle on nitrate leaching. Soil Use and Management 12:190-198.

Hart, S.C., J.M. Stark, E.A. Davidson, and M.K. Firestone. 1994. Nitrogen mineralization, immobilization, and nitrification, p. 985-1018, In Weaver, ed. Methods of soil analysis, Part 2. Microbiological and biochemical properties Vol. 5. Soil Science Society of America Book Series, Madison, Wisconsin, USA.

Hassink, J. 1994. Effects of soil texture and grassland management on soil organic C and N and rates of $\mathrm{C}$ and $\mathrm{N}$ mineralization. Soil Biology \& Biochemistry 26:1221-1231.

Haynes, R.J., and P.H. Williams. 1993. Nutrient cycling and soil fertility in the grazed pasture ecosystem, p. 119-199 Advances in Agronomy, Vol 49, Vol. 49. Academic Press Inc, San Diego.

Hector, A., B. Schmid, C. Beierkuhnlein, M.C. Caldeira, M. Diemer, P.G. Dimitrakopoulos, J.A. Finn, H. Freitas, P.S. Giller, J. Good, R. Harris, P. Hogberg, K. Huss-Danell, J. Joshi, A. Jumpponen, C. Korner, P.W. Leadley, M. Loreau, A. Minns, C.P.H. Mulder, G. O'Donovan, S.J. Otway, J.S. Pereira, A. Prinz, D.J. Read, M. Scherer-Lorenzen, E.D. Schulze, A.S.D. Siamantziouras, E.M. Spehn, A.C. Terry, A.Y. Troumbis, F.I. Woodward, S. Yachi, and J.H. Lawton. 1999. Plant diversity and productivity experiments in European grasslands. Science 286:1123-1127.

Hiremath, A.J., and J.J. Ewel. 2001. Ecosystem nutrient use efficiency, productivity, and nutrient accrual in model tropical communities. Ecosystems 4:669-682.

Hoeft, I., K. Steude, N. Wrage, and E. Veldkamp. 2012. Response of nitrogen oxide emissions to grazer species and plant species composition in temperate agricultural grassland. Agriculture Ecosystems \& Environment 151:34-43.

Holland, E.A., and J.K. Detling. 1990. Plant-response to herbivory and belowground nitrogen cycling. Ecology 71:1040-1049.

Holland, J.N., W.X. Cheng, and D.A. Crossley. 1996. Herbivore-induced changes in plant carbon allocation: Assessment of below-ground C fluxes using carbon-14. Oecologia 107:87-94. 
Holt, J.A. 1997. Grazing pressure and soil carbon, microbial biomass and enzyme activities in semi-arid northeastern Australia. Applied Soil Ecology 5:143-149.

Hooper, D.U., and P.M. Vitousek. 1997. The effects of plant composition and diversity on ecosystem processes. Science 277:1302-1305.

Hooper, D.U., and P.M. Vitousek. 1998. Effects of plant composition and diversity on nutrient cycling. Ecological Monographs 68:121-149.

Howarth, R.W. 1988. Nutrient limitation of net primary production in marine ecosystems. Annual Review of Ecology and Systematics 19:89-110.

IPCC. 2007. Technical Summary, In B. Metz, et al., eds. Climate Change 2007: Mitigation. Contribution of Working Group III to the Fourth Assessment Report of the Intergovernmental Panel on Climate Change. Cambridge University Press, Cambridge, UK.

Isselstein, J., B. Jeangros, and V. Pavlu. 2005. Agronomic aspects of extensive grassland farming and biodiversity management, p. 427-430, In R. Lillak, et al., eds. Integrating efficient grassland farming and biodiversity; 13th international occasional symposium of the European Grassland Federation, Vol. 10, Tartu, Estonia.

Iversen, C.M., S.D. Bridgham, and L.E. Kellogg. 2010. Scaling plant nitrogen use and uptake efficiencies in response to nutrient addition in peatlands. Ecology 91:693-707.

Jackson, L.E., J.P. Schimel, and M.K. Firestone. 1989. Short-term partioning of ammonium and nitrate between plants and microbes in an annual grassland. Soil Biology \& Biochemistry 21:409-415.

Jamieson, N., R. Monaghan, and D. Barraclough. 1999. Seasonal trends of gross N mineralization in a natural calcareous grassland. Global Change Biology 5:423-431.

Jones, S.K., R.M. Rees, U.M. Skiba, and B.C. Ball. 2005. Greenhouse gas emissions from a managed grassland. Global and Planetary Change 47:201-211.

Kahmen, A., J. Perner, V. Audorff, W. Weisser, and N. Buchmann. 2005. Effects of plant diversity, community composition and environmental parameters on productivity in montane European grasslands. Oecologia 142:606-615.

Kammann, C., L. Grunhage, C. Muller, S. Jacobi, and H.J. Jager. 1998. Seasonal variability and mitigation options for $\mathrm{N}_{2} \mathrm{O}$ emissions from differently managed grasslands. Environmental Pollution 102:179-186.

Keeney, D.R., I.R. Fillery, and G.P. Marx. 1979. Effect of temperature on the gaseous nitrogen products of denitrification in a silt loam soil. Soil Science Society of America Journal 43:1124-1128.

Keuffel-Türk, A., A. Jankowski, B. Scheler, P. Rademacher, and H. Meesenburg. in press. Stoffeinträge durch Deposition. In H. Höper and M. H., eds. Tagungsband 20 Jahre Boden-Dauerbeobachtung in Niedersachsen. Landesamt für Bergbau, Energie und Geologie, Hannover.

Keuter, A., I. Hoeft, E. Veldkamp, and M.D. Corre. 2013. Nitrogen response efficiency of a managed and phytodiverse temperate grassland. Plant and Soil 364:193-206.

König, N., and H. Fortmann. 1996. Probenvorbereitungs-, Untersuchungs- und Elementbestimmungs- Methoden des Umweltanalytik-Labor der Niedersächsischen Forstlichen Versuchsanstalt und des Zentrallabor II des Forschungszentrums Waldökosysteme. Teil 1: Elementbestimmungsmethoden A-M. Berichte des Forschungszentrums Waldökosysteme der Universität Göttingen.

Koops, J.G., M.L. van Beusichem, and O. Oenema. 1997. Nitrous oxide production, its source and distribution in urine patches on grassland on peat soil. Plant and Soil 191:57-65.

Krahulec, F., H. Skalova, T. Herben, V. Hadincova, R. Wildova, and S. Pechackova. 2001. Vegetation changes following sheep grazing in abandoned mountain meadows. Applied Vegetation Science 4:97-102. 
Krause, B., H. Culmsee, K. Wesche, E. Bergmeier, and C. Leuschner. 2011. Habitat loss of foodplain meadows in north Germany since the 1050s. Biodiversity and Conservation 20:2347-2364.

Kuzyakov, Y., J.K. Friedel, and K. Stahr. 2000. Review of mechanisms and quantification of priming effects. Soil Biology \& Biochemistry 32:1485-1498.

Ledgard, S.F., S.C. Jarvis, and D.J. Hatch. 1998. Short-term nitrogen fluxes in grassland soils under different long-term nitrogen management regimes. Soil Biology \& Biochemistry 30:1233-1241.

Le Roux, X., M. Bardy, P. Loiseau, and F. Louault. 2003. Stimulation of soil nitrification and denitrification by grazing in grasslands: do changes in plant species composition matter? Oecologia 137:417-425.

Linn, D.M., and J.W. Doran. 1984. Effect of water-filled pore-space on carbon-dioxide and nitrous-oxide production in tilled and nontilled soils. Soil Science Society of America Journal 48:1267-1272.

Loftfield, N., H. Flessa, J. Augustin, and F. Beese. 1997. Automated gas chromatographic system for rapid analysis of the atmospheric trace gases methane, carbon dioxide, and nitrous oxide. Journal of Environmental Quality 26:560-564.

Lovell, R.D., and S.C. Jarvis. 1996. Effects of urine on soil microbial biomass, methanogenesis, nitrification and denitrification in grassland soils. Plant and Soil 186:265-273.

Ma, X.Z., S.P. Wang, Y.F. Wang, G.M. Jiang, and P. Nyren. 2006. Short-term effects of sheep excrement on carbon dioxide, nitrous oxide and methane fluxes in typical grassland of Inner Mongolia. New Zealand Journal of Agricultural Research 49:285297.

Marquard, E., A. Weigelt, V.M. Temperton, C. Roscher, J. Schumacher, N. Buchmann, M. Fischer, W.W. Weisser, and B. Schmid. 2009. Plant species richness and functional composition drive overyielding in a six-year grassland experiment. Ecology 90:32903302.

Mattsson, M., B. Herrmann, S. Jones, A. Neftel, M.A. Sutton, and J.K. Schjoerring. 2009. Contribution of different grass species to plant-atmosphere ammonia exchange in intensively managed grassland. Biogeosciences 6:59-66.

Mikola, J., G.W. Yeates, G.M. Barker, D.A. Wardle, and K.I. Bonner. 2001. Effects of defoliation intensity on soil food-web properties in an experimental grassland community. Oikos 92:333-343.

Mikola J., H. Setala, P. Virkajarvi, K. Saarijarvi, K. Ilmarinen, W. Voigt, and M. Vestberg. 2009. Defoliation and patchy nutrient return drive grazing effects on plant and soil properties in a dairy cow pasture. Ecological Monographs 79:221-244.

Mooney, H.A., and W.E. Winner. 1991. Partitioning response of plants to stress, p. 129-141, In $\mathrm{H}$. A. Mooney, et al., eds. Responses of plants to multiple stresses. Academic Press, San Diego.

Mosier, A.R., J.M. Duxbury, J.R. Freney, O. Heinemeyer, and K. Minami. 1996. Nitrous oxide emissions from agricultural fields: Assessment, measurement and mitigation. Plant and Soil 181:95-108.

Naeem, S., L.J. Thompson, S.P. Lawler, J.H. Lawton, and R.M. Woodfin. 1994. Declining biodiversity can alter the performance of ecosystems. Nature 368:734-737.

Niklaus, P.A., E. Kandeler, P.W. Leadley, B. Schmid, D. Tscherko, and C. Korner. 2001. A link between plant diversity, elevated $\mathrm{CO}_{2}$ and soil nitrate. Oecologia 127:540-548.

Niklaus, P.A., D.A. Wardle, and K.R. Tate. 2006. Effects of plant species diversity and composition on nitrogen cycling and the trace gas balance of soils. Plant and Soil 282:83-98. 
Northup, B.K., J.R. Brown, and J.A. Holt. 1999. Grazing impacts on the spatial distribution of soil microbial biomass around tussock grasses in a tropical grassland. Applied Soil Ecology 13:259-270.

Nösberger, J., and M. Rodriguez. 1996. Increasing biodiversity through management. Grassland Science in Europe 1:949-956.

Oelmann, Y., Y. Kreutziger, V.M. Temperton, N. Buchmann, C. Roscher, J. Schumacher, E.D. Schulze, W.W. Weisser, and W. Wilcke. 2007. Nitrogen and phosphorus budgets in experimental grasslands of variable diversity. Journal of Environmental Quality 36:396-407.

Oenema, O., G.L. Velthof, S. Yamulki, and S.C. Jarvis. 1997. Nitrous oxide emissions from grazed grassland. Soil Use and Management 13:288-295.

Pastor, J., and S.D. Bridgham. 1999. Nutrient efficiency along nutrient availability gradients. Oecologia 118:50-58.

Petersen, U., N. Wrage, L. Köhler, C. Leuschner, and J. Isselstein. 2012. Manipulating the species composition of permanent grasslands - A new approach to biodiversity experiments. Basic and Applied Ecology 13:1-9.

Piepho, H.P., A. Buchse, and C. Richter. 2004. A mixed modelling approach for randomized experiments with repeated measures. Journal of Agronomy and Crop Science 190:230-247.

Poschlod, P., and S. Bonn. 1998. Changing dispersal processes in the central European landscape since the last ice age: an explanation for the actual decrease of plant species richness in different habitats? Acta Botanica Neerlandica 47:27-44.

Pykälä, J. 2000. Mitigating human effects on European biodiversity through traditional animal husbandry. Conservation Biology 14:705-712.

R Development Core Team. 2009. R: A language and environment for statistical computing. R Foundation for Statistical Computing, Vienna, Austria.

Rose, L., H. Coners, and C. Leuschner. 2011a. Effects of fertilization and cutting frequency on the water balance of a temperate grassland. Ecohydrology 5:64-72.

Rose, L. 2011b. The influence of land-use intensification and biodiversity on grassland biomass, water use and plant functional traits. $\mathrm{PhD}$ thesis, University of Göttingen.

Roy, J. 2001. How does biodiversity control primary productivity?, In J. Roy, et al., eds. Terrestrial global productivity. Academic Press, San Diego.

Ruser, R., H. Flessa, R. Schilling, H. Steindl, and F. Beese. 1998. Soil compaction and fertilization effects on nitrous oxide and methane fluxes in potato fields. Soil Science Society of America Journal 62:1587-1595.

Saggar, S., C.B. Hedley, D.L. Giltrap, and S.M. Lambie. 2007. Measured and modelled estimates of nitrous oxide emission and methane consumption from a sheep-grazed pasture. Agriculture Ecosystems \& Environment 122:357-365.

Sahin Demirbag, N., K.U. Röver, N. Wrage, M. Hofmann, and J. Isselstein. 2009. Herbage growth rates on heterogeneous swards as influenced by sward-height classes. Grass and Forage Science 64:12-18.

Sankaran, M., and D.J. Augustine. 2004. Large herbivores suppress decomposer abundance in a semiarid grazing ecosystem. Ecology 85:1052-1061.

Scherer-Lorenzen, M., C. Palmborg, A. Prinz, and E.D. Schulze. 2003. The role of plant diversity and composition for nitrate leaching in grasslands. Ecology 84:1539-1552.

Schlesinger, W.H. 2009. On the fate of anthropogenic nitrogen. Proceedings of the National Academy of Sciences of the United States of America 106:203-208.

Schlichting, E., Blume, H.P., Stahr, K. 1995. Bodenkundliches Praktikum. 2 ed. Blackwell Wissenschafts-Verlag, Berlin, Wien. 
Seither, M., N. Wrage, and J. Isselstein. 2012. Sward composition and grazer species effects on nutritive value and herbage accumulation. Agronomy Journal 104:497-506.

Seither, M., U. Petersen, N. Wrage, and J. Isselstein. 2010. Effect of mono- and mixed grazing of cattle and sheep on grassland diversity patterns. Grassland Science in Europe 15:755-757.

Shand, C.A., B.L. Williams, L.A. Dawson, S. Smith, and M.E. Young. 2002. Sheep urine affects soil solution nutrient composition and roots: differences between field and sward box soils and the effects of synthetic and natural sheep urine. Soil Biology \& Biochemistry 34:163-171.

Sherlock, R.R., and K.M. Goh. 1983. Initial emission of nitrous-oxide from sheep urine applied to pasture soil. Soil Biology \& Biochemistry 15:615-617.

Shuttleworth, W.J., and J.S. Wallace. 1985. Evaporation from sparse crops - an energy combination theory. Quarterly Journal of the Royal Meteorological Society 111:839855.

Spehn, E.M., M. Scherer-Lorenzen, B. Schmid, A. Hector, M.C. Caldeira, P.G. Dimitrakopoulos, J.A. Finn, A. Jumpponen, G. O'Donnovan, J.S. Pereira, E.D. Schulze, A.Y. Troumbis, and C. Korner. 2002. The role of legumes as a component of biodiversity in a cross-European study of grassland biomass nitrogen. Oikos 98:205218.

Spehn, E.M., A. Hector, J. Joshi, M. Scherer-Lorenzen, B. Schmid, E. Bazeley-White, C. Beierkuhnlein, M.C. Caldeira, M. Diemer, P.G. Dimitrakopoulos, J.A. Finn, H. Freitas, P.S. Giller, J. Good, R. Harris, P. Hogberg, K. Huss-Danell, A. Jumpponen, J. Koricheva, P.W. Leadley, M. Loreau, A. Minns, C.P.H. Mulder, G. O'Donovan, S.J. Otway, C. Palmborg, J.S. Pereira, A.B. Pfisterer, A. Prinz, D.J. Read, E.D. Schulze, A.S.D. Siamantziouras, A.C. Terry, A.Y. Troumbis, F.I. Woodward, S. Yachi, and J.H. Lawton. 2005. Ecosystem effects of biodiversity manipulations in European grasslands. Ecological Monographs 75:37-63.

Tasser, E., and U. Tappeiner. 2002. Impact of land use changes on mountain vegetation. Applied Vegetation Science 5:173-184.

Tilman, D., D. Wedin, and J. Knops. 1996. Productivity and sustainability influenced by biodiversity in grassland ecosystems. Nature 379:718-720.

Tscharntke, T., A.M. Klein, A. Kruess, I. Steffan-Dewenter, and C. Thies. 2005. Landscape perspectives on agricultural intensification and biodiversity - ecosystem service management. Ecology Letters 8:857-874.

Van Groenigen, J.W., P.J. Kuikman, W.J.M. De Groot, and G.L. Velthof. 2005. Nitrous oxide emission from urine-treated soil as influenced by urine composition and soil physical conditions. Soil Biology \& Biochemistry 37:463-473.

Van Kessel, C., T. Clough, and J.W. Van Groenigen. 2009. Dissolved organic nitrogen: an overlooked pathway of nitrogen loss from agricultural systems? Journal of Environmental Quality 38:393-401.

Van Ruijven, J., and F. Berendse. 2005. Diversity-productivity relationships: Initial effects, long-term patterns, and underlying mechanisms. Proceedings of the National Academy of Sciences of the United States of America 102:695-700.

Vitousek, P. 1982. Nutrient cycling and nutrient use efficiency. American Naturalist 119:553572.

Vitousek, P.M., and R.W. Howarth. 1991. Nitrogen limitation on land and in the sea - how can it occur. Biogeochemistry 13:87-115.

Vitousek, P.M., H.A. Mooney, J. Lubchenco, and J.M. Melillo. 1997. Human domination of Earth's ecosystems. Science 277:494-499. 
Wachendorf, C., C. Lampe, F. Taube, and K. Dittert. 2008. Nitrous oxide emissions and dynamics of soil nitrogen under $\mathrm{N}$-15-labeled cow urine and dung patches on a sandy grassland soil. Journal of Plant Nutrition and Soil Science-Zeitschrift Fur Pflanzenernährung Und Bodenkunde 171:171-180.

Watson, C.J., and C.L. Mills. 1998. Gross nitrogen transformations in grassland soils as affected by previous management intensity. Soil Biology \& Biochemistry 30:743-753.

Weigelt, A., W.W. Weisser, N. Buchmann, and M. Scherer-Lorenzen. 2009. Biodiversity for multifunctional grasslands: equal productivity in high-diversity low-input and lowdiversity high-input systems. Biogeosciences 6:1695-1706.

Wesche, K., B. Krause, H. Culmsee, and C. Leuschner. 2009. Veränderungen in der FlächenAusdehnung und Artenzusammensetzung des Feuchtgrünlandes in Norddeutschland seit den 1050er Jahren. Berichte der Reinhold-Tüxen-Gesellschaft 21:196-210.

Williams, D.L., P. Ineson, and P.A. Coward. 1999. Temporal variations in nitrous oxide fluxes from urine-affected grassland. Soil Biology \& Biochemistry 31:779-788.

Williams, P.H., and R.J. Haynes. 1994. Comparison of initial wetting pattern, nutrient concentrations in soil solution and the fate of ${ }^{15} \mathrm{~N}$-labeled urine in sheep and cattle urine patch areas of pasture soil. Plant and Soil 162:49-59.

Wrage, N., J. Strodthoff, M.H. Cuchillo, J. Isselstein, and M. Kayser. 2011. Phytodiversity of temperate permanent grasslands: Ecosystem services for agriculture and livestock management for diversity conservation. Biodiversity and Conservation 20:3317-3339.

Yamulki, S., I. Wolf, R. Bol, B. Grant, R. Brumme, E. Veldkamp, and S.C. Jarvis. 2000. Effects of dung and urine amendments on the isotopic content of $\mathrm{N}_{2} \mathrm{O}$ released from grasslands. Rapid Communications in Mass Spectrometry 14:1356-1360.

Xu, G., X. Fan, and A.J. Miller. 2012. Plant nitrogen assimilation and use efficiency. Annual Review of Plant Biology 63:153-182.

Yuan, Z.Y., L.H. Li, X.G. Han, S.P. Chen, Z.W. Wang, Q.S. Chen, and W.M. Bai. 2006. Nitrogen response efficiency increased monotonically with decreasing soil resource availability: a case study from a semiarid grassland in northern China. Oecologia 148:564-572.

Zuur, A.F., E.N. Ieno, N.J. Walker, A.A. Saveliev, and G.M. Smith. 2009. Mixed effects models and extensions in ecology with R, statistics for biology and health. New York: Springer Science + Business Media. 


\section{APPENDIX}

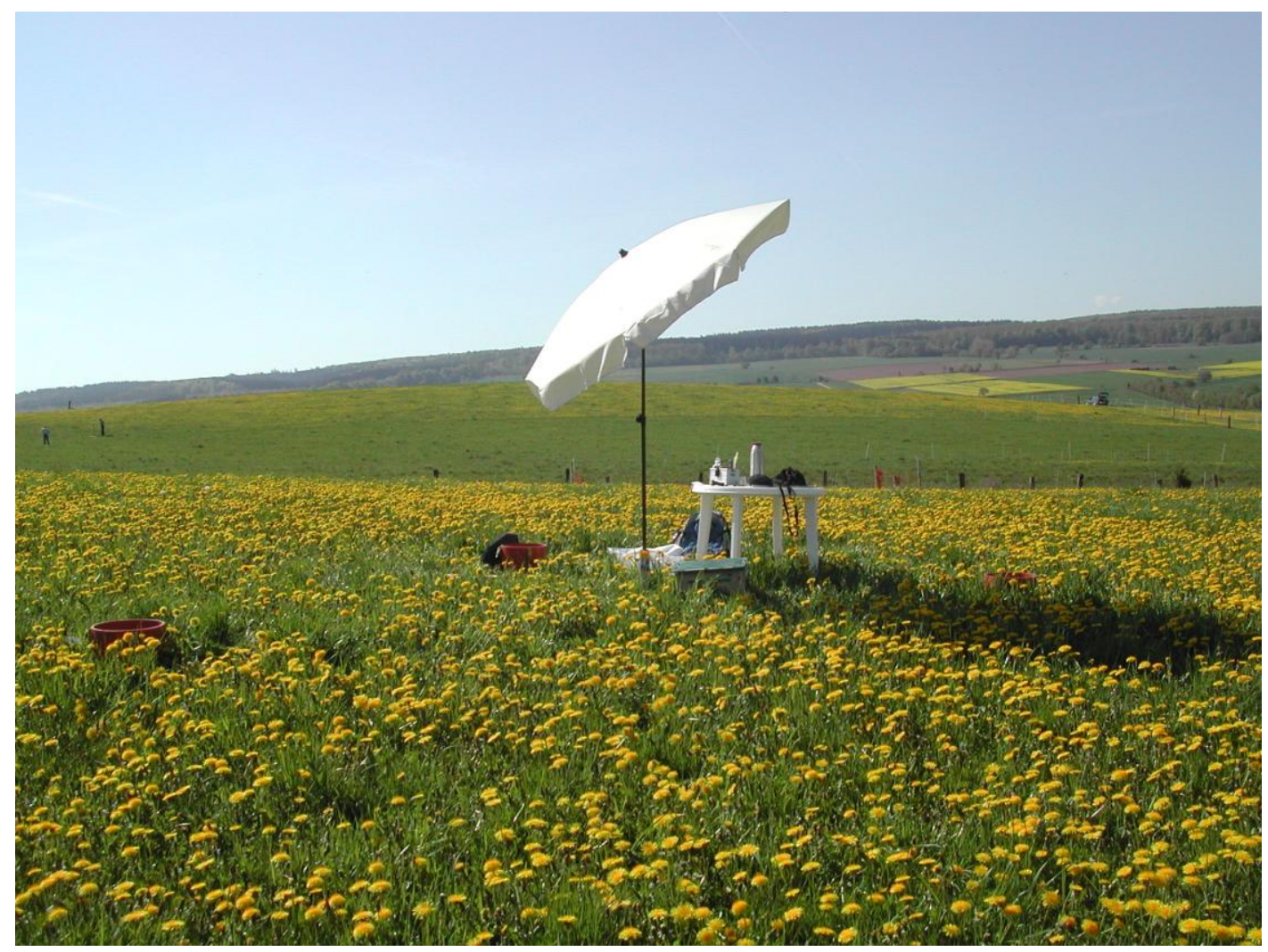

Figure A.1 BIOMIX experiment with different swards in spring 2008.
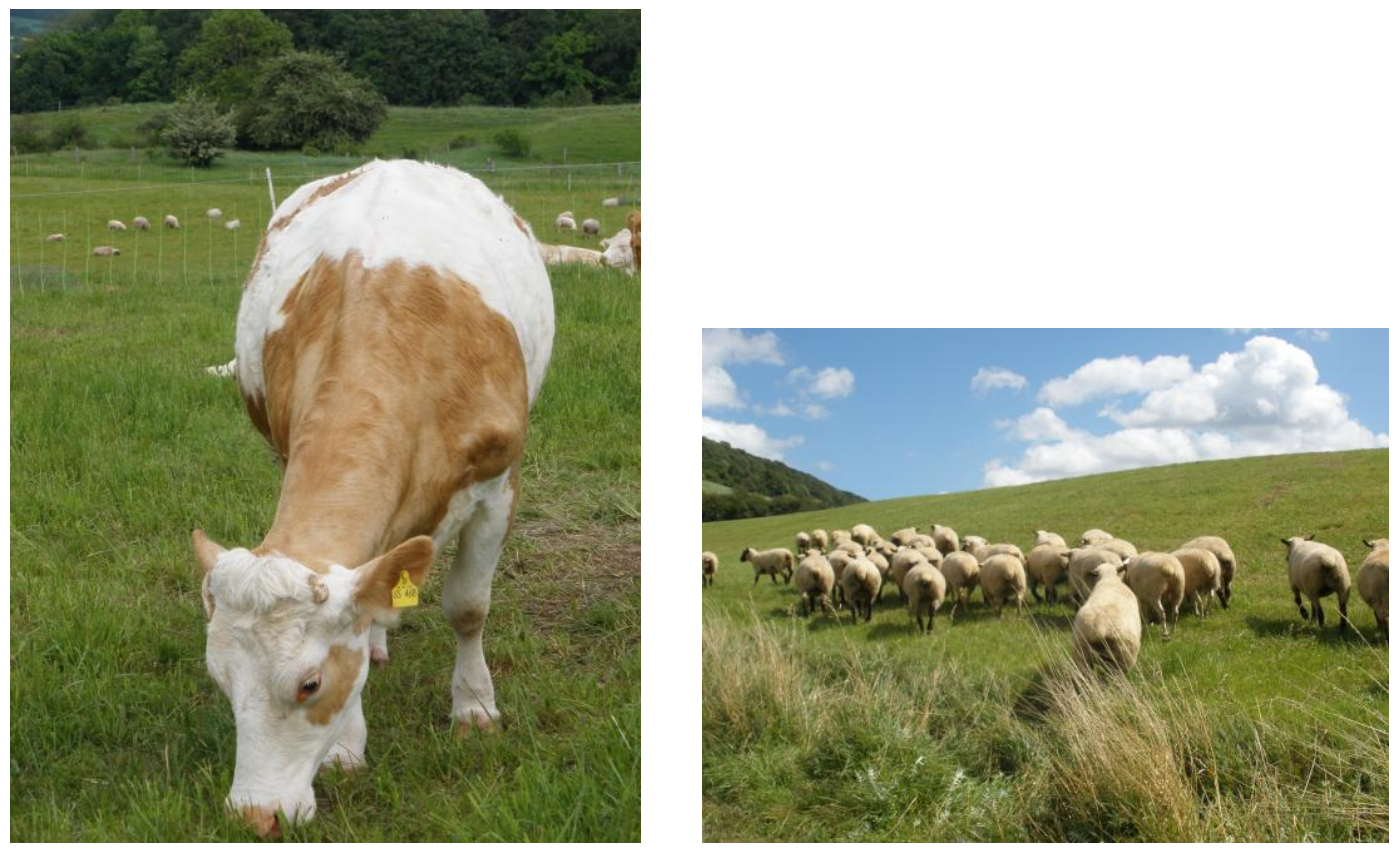

Figure A.2 BIOMIX experiment with cattle and sheep grazing in spring 2008. 


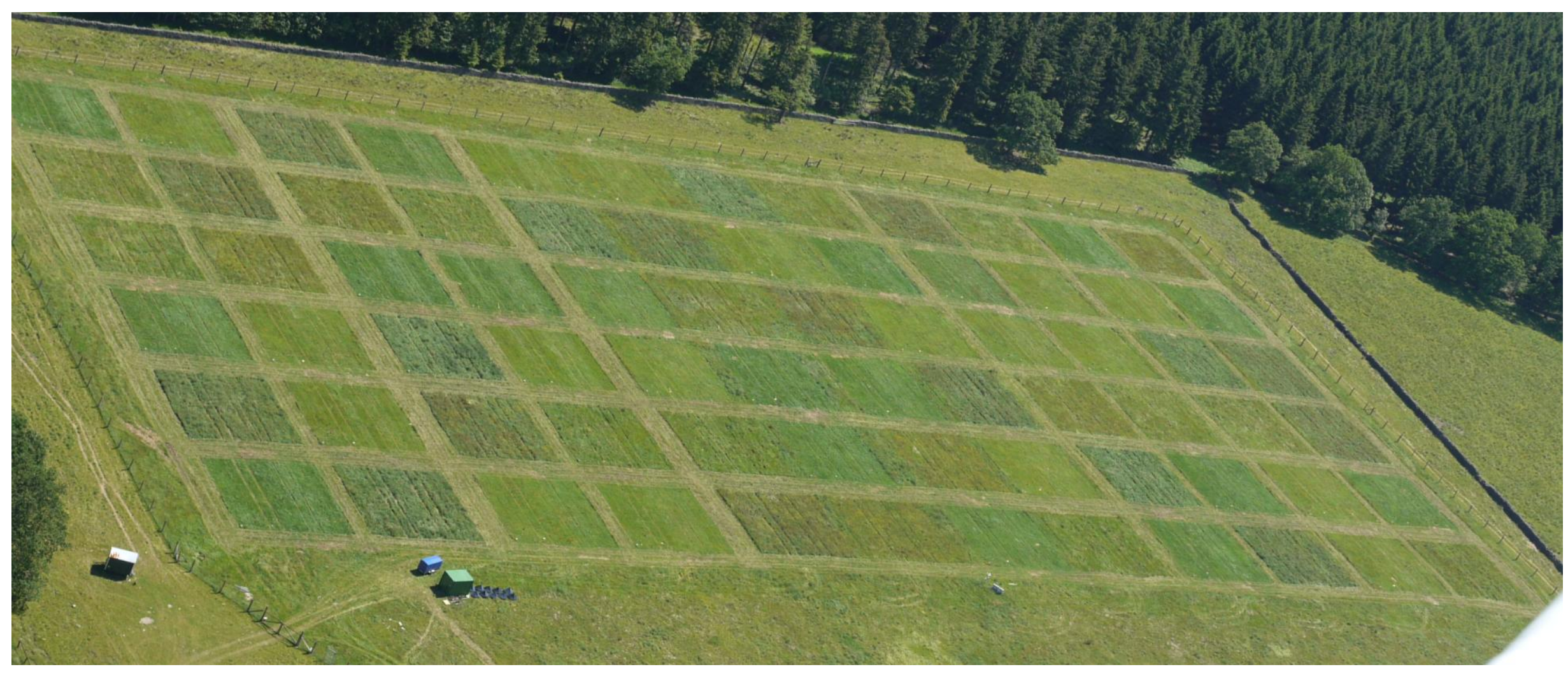

Figure A.3 GRASSMAN experiment in summer 2009. Photograph: Laura Rose. 
Table A.1 Biomass yield of a grassland under different management practices in the Solling Mountains, Germany.

\begin{tabular}{|c|c|c|c|c|c|c|c|c|c|c|}
\hline \multirow[b]{2}{*}{ Main factors } & \multirow[b]{2}{*}{ Treatments } & \multirow[b]{2}{*}{$\mathrm{n}$} & \multicolumn{4}{|c|}{2009} & \multicolumn{4}{|c|}{2010} \\
\hline & & & $\begin{array}{l}\text { Biomass yield * } \\
\left(\mathrm{kg} \mathrm{ha}^{-1} \mathrm{yr}^{-1}\right)\end{array}$ & SE & $P$ & $\begin{array}{l}\text { Variance } \\
\text { explained } \\
(\%)\end{array}$ & $\begin{array}{l}\text { Biomass yield * } \\
\left(\mathrm{kg} \mathrm{ha}^{-1} \mathrm{yr}^{-1}\right)\end{array}$ & $\mathrm{SE}$ & $P$ & $\begin{array}{l}\text { Variance } \\
\text { explained } \\
(\%)\end{array}$ \\
\hline \multirow[t]{4}{*}{ Sward compos } & & & & & 0.648 & 0.28 & & & 0.007 & 2.34 \\
\hline & control & 24 & 7922.82 a & 597. & & & $6132.01 \mathrm{a}$ & 536.79 & & \\
\hline & monocot-enhanced & 24 & $7763.22 \mathrm{a}$ & 508. & & & $5237.22 \mathrm{~b}$ & 498.97 & & \\
\hline & dicot-enhanced & 24 & $7586.48 \mathrm{a}$ & 482. & & & $5467.27 \mathrm{ab}$ & 467.66 & & \\
\hline \multirow[t]{3}{*}{ Mowing freque } & & & & & 0.000 & 12.01 & & & 0.000 & 34.92 \\
\hline & once per year & 36 & $6855.40 \mathrm{~b}$ & 270. & & & $4146.09 \mathrm{~b}$ & 172.92 & & \\
\hline & thrice per year & 36 & 8659.62 a & 517. & & & $7078.25 \mathrm{a}$ & 446.14 & & \\
\hline \multirow[t]{3}{*}{ Fertilization } & & & & & 0.000 & 56.74 & & & 0.000 & 24.71 \\
\hline & no & 36 & $5797.13 \mathrm{~b}$ & 167. & & & $4378.75 \mathrm{~b}$ & 210.25 & & \\
\hline & NPK & 36 & 9717.88 a & 373. & & & 6845.59 a & 469.71 & & \\
\hline \multicolumn{2}{|c|}{ Mowing frequency $\mathrm{x}$ fertilization } & & & & 0.000 & 9.89 & & & 0.000 & 16.97 \\
\hline once per year & no & 18 & $5713.66 \mathrm{c}$ & 160. & & & $3934.60 \mathrm{~b}$ & 248.95 & & \\
\hline once per year & NPK & 18 & $7997.14 \mathrm{~b}$ & 349. & & & $4357.58 \mathrm{~b}$ & 236.35 & & \\
\hline thrice per year & no & 18 & $5880.61 \mathrm{c}$ & 297. & & & $4822.89 \mathrm{~b}$ & 311.13 & & \\
\hline thrice per year & NPK & 18 & 11438.62 a & 321. & & & $9333.61 \mathrm{a}$ & 352.58 & & \\
\hline
\end{tabular}

* Biomass yield data was reported by From et al. (2011).

Mean values with different letter indicate significant differences among treatments within main factors or within an interaction of main factors (three-way ANOVA with Tukey HSD at $P \leq 0.05$ ). Treatment interactions that were not significant are not reported. 


\section{ACKNOWLEDGEMENTS}

Many people have supported me during my Ph.D journey, without whom I would not have finished. First, I would like to thank Prof. Edzo Veldkamp, for providing an interesting and challenging research topic, and for enabling me to conduct that research. I also would like to thank Dr. Marife Corre and Prof. Nicole Wrage for critical and constructive comments on my thesis; I learned a lot. To my supervisors and Prof. Nicole Wrage: what I will remember most is that your doors were always open and even in difficult times you supported me. Thank you.

I wish to thank Prof. Heiner Flessa, who assisted me during the first part of my Ph.D.

Thanks to my dear colleague Andreas Keuter, for his motivation and for his collaboration on our manuscripts. He is a real team player and I'm not sure he is ever in a bad mood.

This work is part of the Cluster of Excellence 'Functional Biodiversity Research' and has been funded by the State of Lower Saxony, the Ministry of Science and Culture and the Niedersächsisches Vorab. Within this framework, the most important people were my GRASSMAN colleagues: Dr. Laura Rose, Ute Petersen, Dr. Lana Dobrindt and Tatiana From. I really enjoyed working and discussing with you. I also want to thank my BIOMIX colleagues: Arne Oppermann, Knut Salzmann, Dr. Melanie Seither and Barbara Hohlmann. Special thanks go to Dr. Lars Köhler, our coordinator.

I want to say thank you to all of my friends and colleagues at the institute for the support, and for everything else that made the time unforgettable! Here I would especially like to mention Dr. Katrin Wolf, Dr. Nadine Eickenscheidt, Christina Langenbruch, Marleen de Blécourt, Anja Bergstermann, Angelica Baldos, Juvia Sueta, Dr. Peter Gernandt and Wolfram Eschenbach.

The experimental set up with Dirk Böttger was the most enjoyable time. If you need something whatever it might be - ask Dirk and he'll know where and how to get it. I also love to remember how Dirk got stuck in the electric fence. It was possible to see his skeleton! I also have to mention my other supporters during experimental set up, field and lab measurements. Thank go to: Niels-Christian Meyer, Christoph Gottwald and Philipp Aurin. 
I was not able to conduct all my work by myself and therefore I want to thank the laboratory team for handling and measuring my samples, for advice, and especially for the nice working atmosphere. I, specifically, like to thank Karin Schmidt, Ingrid Ostermeyer and Kerstin Langs. I would also like to thank Dr. Norman Loftfield for technical support in the lab. I am also grateful to the staff of the "Centre for Stable Isotope Research and Analysis" for their very fast measurements. I am much obliged to Erwin Tönges and Dr. Henning Meesenburg for providing the meteorological and $\mathrm{N}$ deposition data for our study sites. I would like to express my appreciation to Dr. Christoph Scherber for his statistical advice. Special thanks to my Master's students, Jeetendra Mahat, Cecille Marie O. Quiñones and Karin Steude, who worked very conscientiously and delivered very useful data. Without their help the Ph.D work would not be the same.

Special thanks go to all my friends and to my flat mates Anja, Christina, Jakob and Oliver, who have been a great support during the last years.

Last but not least, I remain grateful to my family, who always join in all my "crazy ideas" ... 


\section{DECLARATION OF ORIGINALITY AND CERTIFICATE OF AUTHORSHIP}

I, Ina Hoeft, hereby declare that I am the sole author of this dissertation entitled "GrASSLAND Management and Diversity EfFects on Soil Nitrogen Dynamics and Losses”. All references and data sources that were used in the dissertation have been appropriately acknowledged. I furthermore declare that this work has not been submitted elsewhere in any form as part of another dissertation procedure. I certify that the manuscripts presented in chapters 2, 3 and 4 have been written by me as first author.

Göttingen, January 2012

(Ina Hoeft) 


\section{Curriculum Vitae}

PERSONAL INFORMATION

\begin{tabular}{ll}
\hline Name & Ina Hoeft \\
Date of birth & 10.10 .1974 \\
Place of birth & Stade
\end{tabular}

\section{EDUCATION AND RESEARCH EXPERIENCE}

03/2008-08/2011 Georg-August-University OF GötTINGEN, SOIL SCIENCE OF TROPCIAL AND SUBTROPICAL ECOSYSTEMS

Scholarship in the Cluster of Excellence „Functional Biodiversity Research“"

Since 09/2011 GeOrg-August-University of GötTINGEN, SoIL ScIENCE OF TROPCIAL AND SUBTROPICAL ECOSYSTEMS

Research Assistant at the Büsgen Institute

$\mathrm{PhD} /$ Doctorate

Since $03 / 2008$

GeORg-August University GötTINGEN, CENTRE FOR BIODIVERSITY AND ECOLOGY

Ph.D. Program: Biological Diversity and Ecology

Academic Studies

2000- 2007

\section{UNIVERSITY OF LÜNEBURG}

DiPLOMA (EQUIVALENT TO M.SC.) IN ENVIRONMENTAL SCIENCES

Thesis: "Impact of land use history on soil ecological properties in Eastern Mediterranean (Israel, Galilee)"

Major: Ecology (Soil Science) and Environmental Communication

\section{CONFERENCES}

Hoeft, I., Keuter, A., VeldKAMP, E., CoRRE, M.D. (2011): Nitrogen Response Efficiency of a Managed and Phytodiverse Temperate Semi-natural Grassland. Functions and Services of Biodiversity, Göttingen (Poster).

HoEfT, I., VeldKamp, E., Wrage, N. (2010): Effects of Functional Grassland Diversity and Different Management Intensities on Net N Mineralisation. Gesellschaft für Ökologie, Gießen (Talk).

HoEfT I., VeldKAmP E., Flessa H., Wrage N. (2009): Impact of Grazers and Grassland Diversity on Nitrogen Oxide Emissions. Deutsche Bodenkundliche Gesellschaft, Bonn (Poster). 